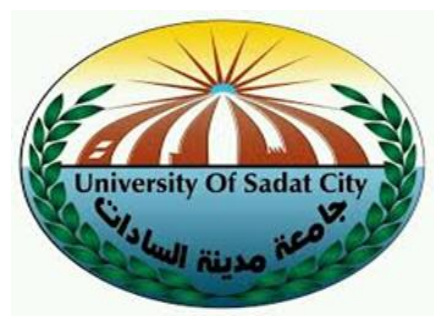

جامعة مدينة السادات

كبة التزبية

قسنم التزبية

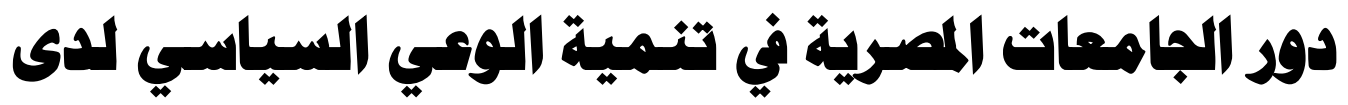 |
}

مستخلص بحث مقدم ضمن متطلبات الحصول على درجة الماجستير في التربية

\author{
إعداد الباحثة \\ أمل جريان سعود جريان
}

أ.د/عبدالتاصر سعيد عطايا

أستاذ ورئيس قسم أصول التربية

كلية التربية - جامعة الأزهر التربية

أدد/ زهير السعيد هجازي

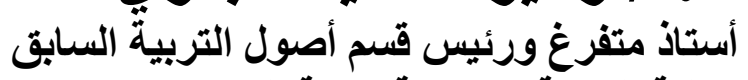

كلية التربية - جامعة مدينة السادات

$01 \leqslant r d-5 r \cdot 11$ 
هدف البحث إلى التعرف على دور الجامعات المصرية في تتمية الوعي السياسي لدى

الطـلاب الكويتين. واستعرض البحث دور كل مـن عضـو هيئة التدريس، المقررات الدراسية،

الأنشطة الجامعيـة الخاصـة بالاتحادات الطلابيـة، والمنـاخ الجامعي في تنمية الوعي السياسي

لطلاب الجامعة الكويتين. وتوصل البحث إلى أن المناخ الجامعي إذا كان صحيا سليما مشعبا

بالفهم والتقدير المتبادل وقيم العدالة والحريـة والمساواة، فأنه بـلا شك سيساعد على تتشئة الفرد سياسيا. اما عن الأنشطة الطلابية جاءت النتائج مشيرة الى أن الأنشطة التي يمارسها الطلاب داخل الجامعات ليست على صلة وثيقة بالجانب السياسي، ولا تلبي احتياجات الطلاب بواقعها الحالي. وفيما يخص اعضاء هيئة التدريس فقد جاءت النتائج مشيرة الى أن اهتمام عضو هيئة التدريس بالميدان السياسـي، إلا أنه لا يؤديـه بالثكل المطلوب. وأوصت الدراسـة بضـرورة تبني عضو هيئة التدريس لفلسفة الحوار، وتقبل الاختلاف في الآراء بين الطلاب. واتاحة الغرصـة له من قبل الجامعة، وضرورة وضع مقررات تتضمن جانب سياسي يتوافق والوضع الحالي.

\section{The objective of the research;}

The aim of the research is to identify the role of Egyptian universities in developing political awareness among Kuwaiti students. The research reviewed the role of faculty members, courses, university activities of student associations, and the university climate in developing political awareness of Kuwait University students. The research concluded that if the university climate is healthy and healthy, with understanding, mutual appreciation and the values of justice, freedom and equality, it will undoubtedly help to nurture the individual Politically. As for the student activities came the results, noting that the activities carried out by students within the universities are not closely related to the political side, and does not meet the needs of the students current reality. With regard to the members of the faculty, the results came, noting that the interest of the faculty member in the political field, but it does not perform as required. The study recommended that a faculty member adopt a philosophy of dialogue and accept differences of opinion among students. And the opportunity for him by the university, and the need to develop decisions include a political aspect corresponds to the current situation. 
مع نهاية العقد الأول من القرن الحادي والعشرين بدأت بعض الحركات الاحتجاجية التي

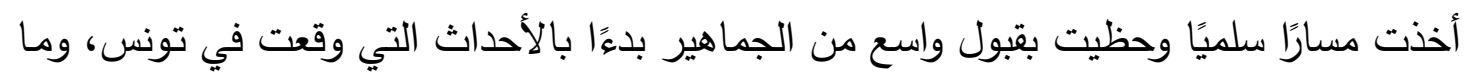

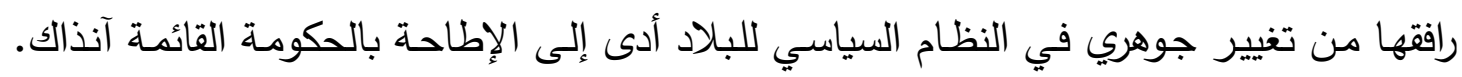
انتقلت بعد ذلك إلى بلدان عربية أخرى، وكانت هناك مجموعة من العوامل والأسباب الداخلية

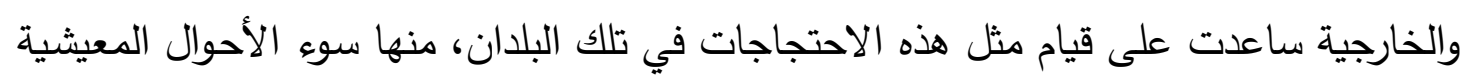

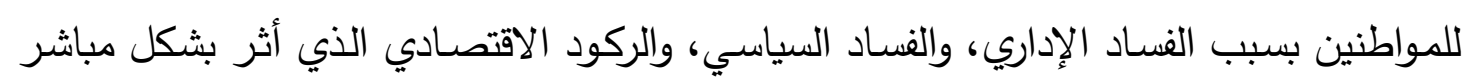

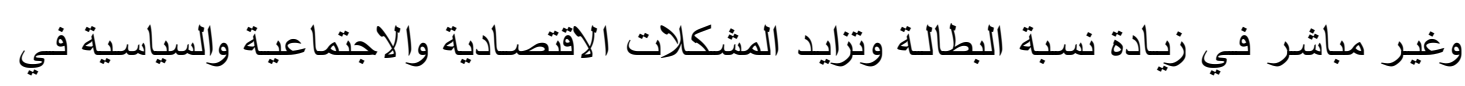
البلدان التي حدثت فيها تلك الأحداث.

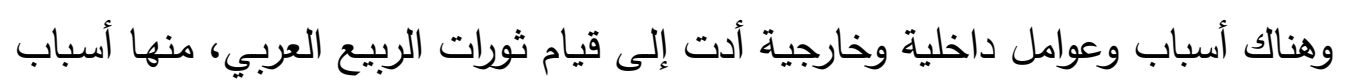

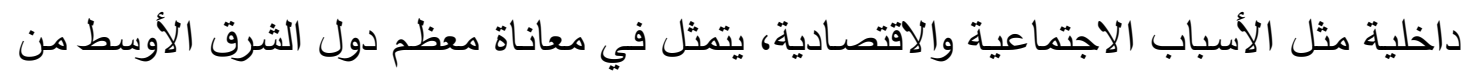

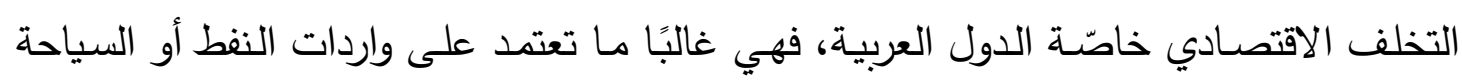
والمعونات الخارجية في حين تغيب التتمية الحقيقية بسبب صعوبات تتمثّل في ارتفاع معدل تزايد

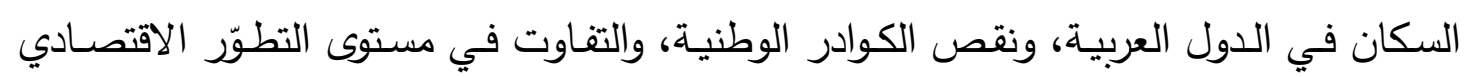

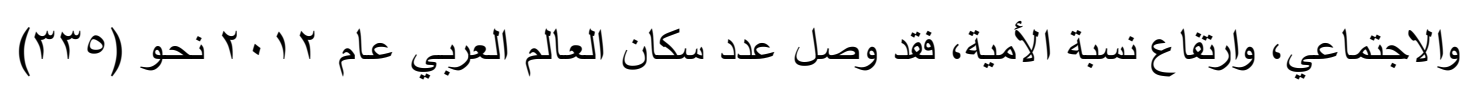

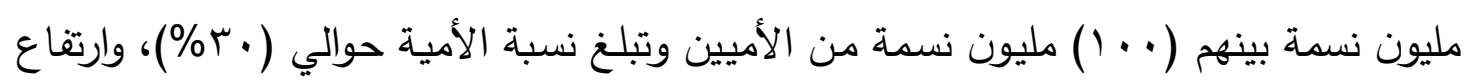

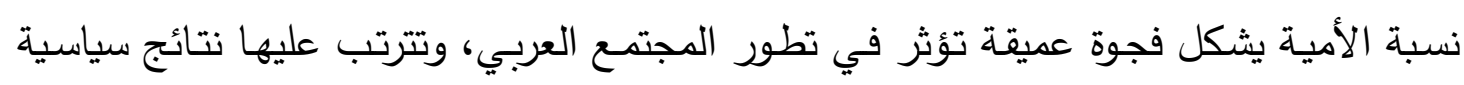
واجتماعية خطيرة. (1)

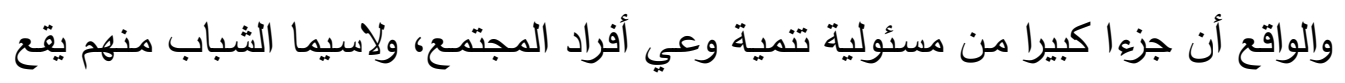
على عاتق الجامعة باعتبارها من أهم وسائط التربية، إلى جانب كونها أهم المراحل التعليمية التي ولي التئي

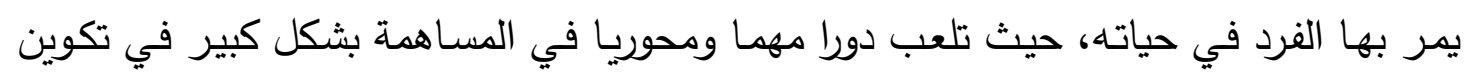

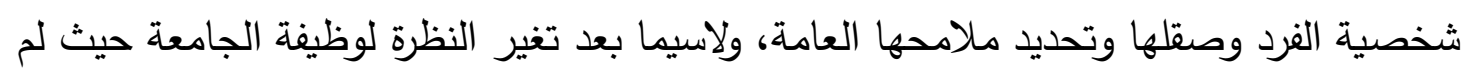
تعد قاصرة على البحث في المعرفة ونقلها، وإنما أصبح ينظر إليها على أنها مصدر مهم لتزويد

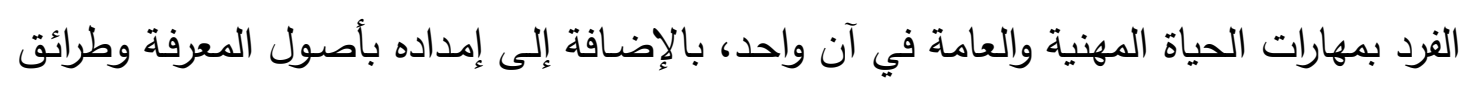

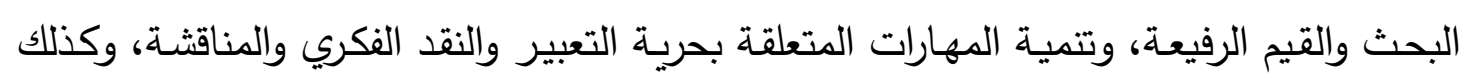

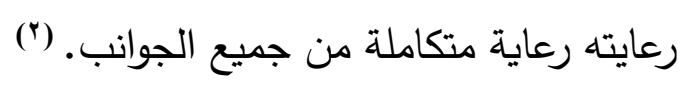

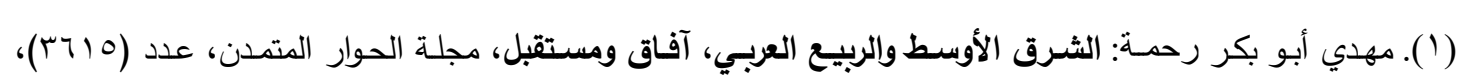

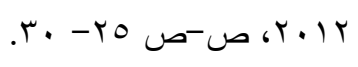

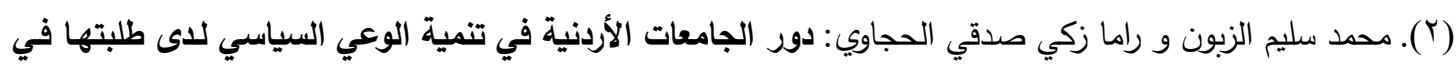

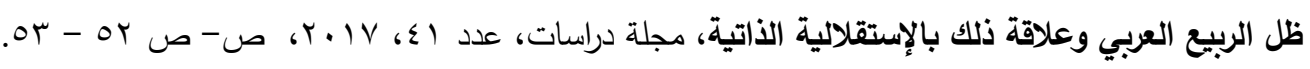


وفي حقيقة الأمر، فإنـه إذا أخذ بوجهة النظر القائلة بأن السياسة هي الموضوع الذي

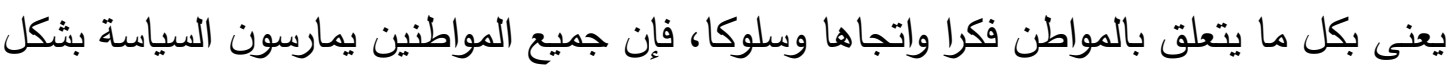

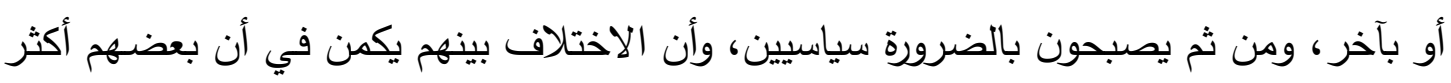

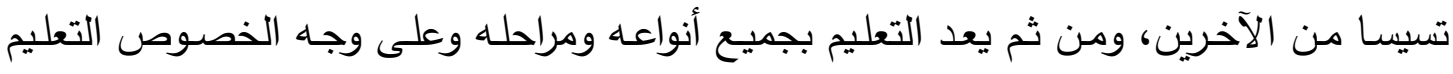

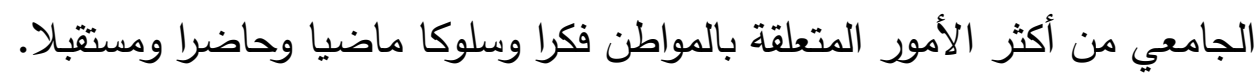

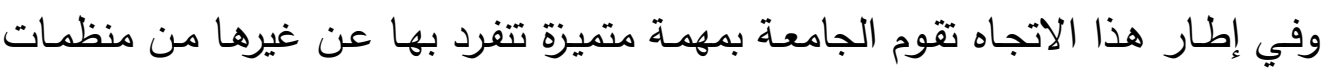

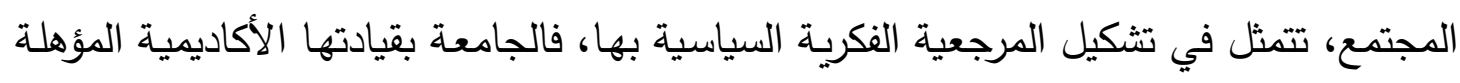

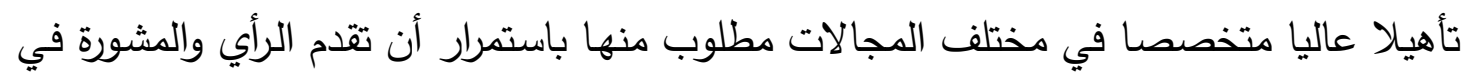

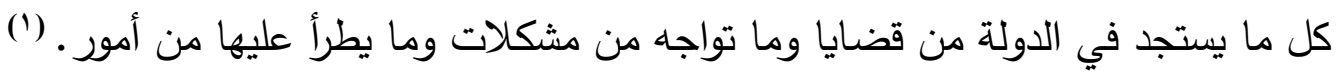

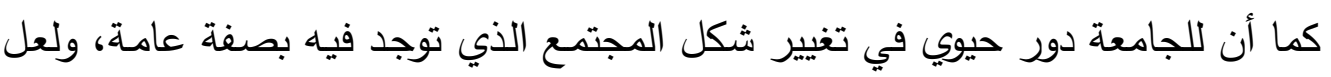

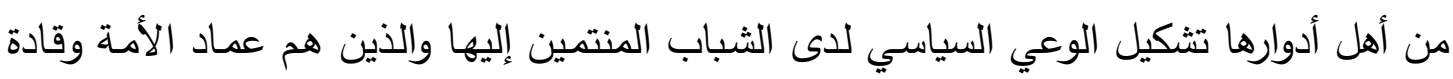

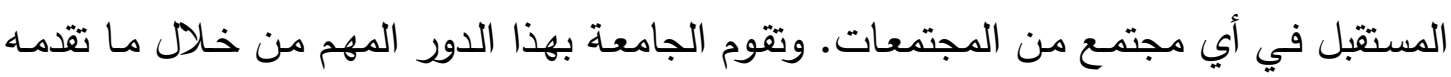

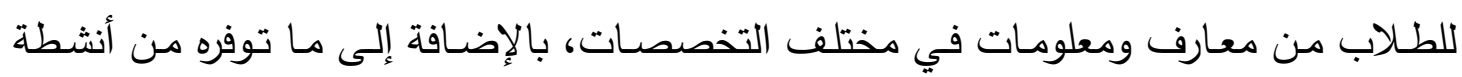

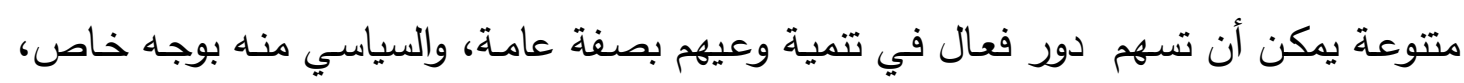

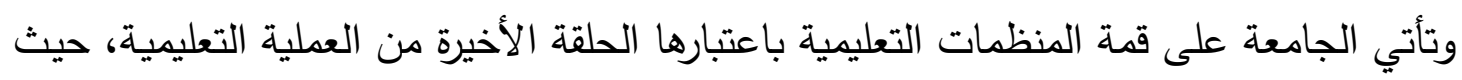

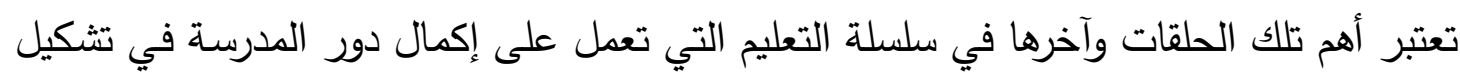

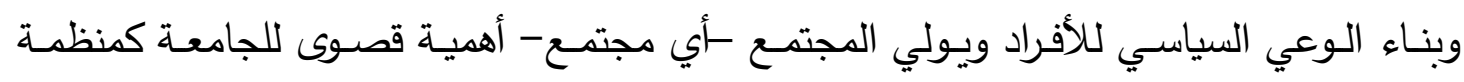

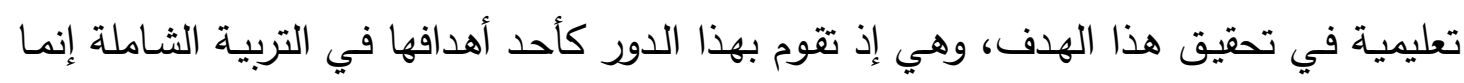
تعمل على إعداد الثباب للخروج إلى الحياة العملية في المجتمع والقيام بدورهم على أكمل وجها.

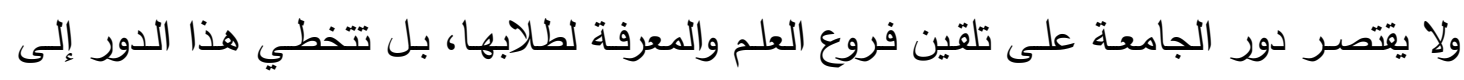

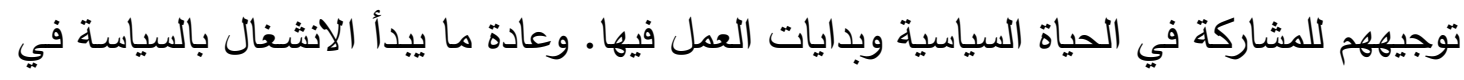

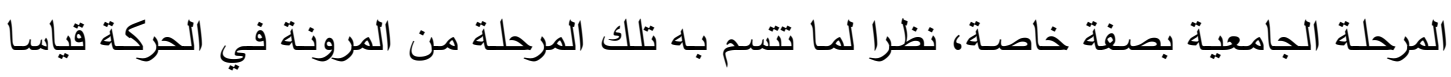

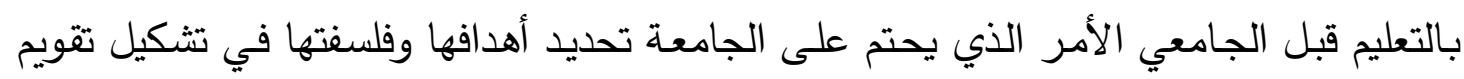

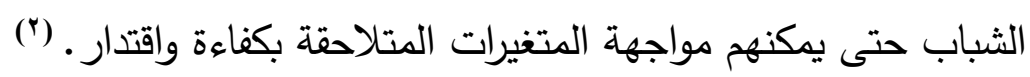

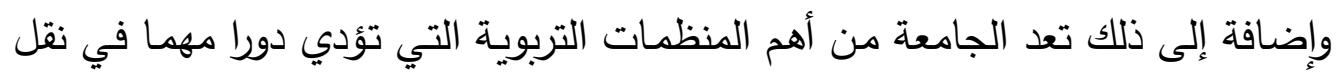

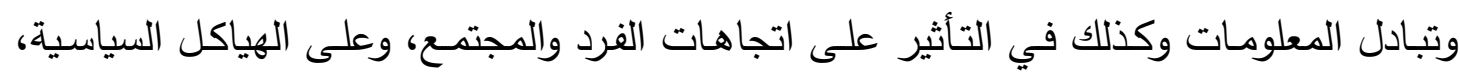

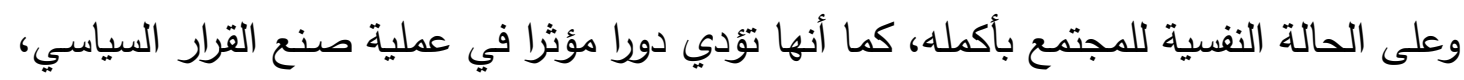
(1). كمال المنوفي، وحسنين توفيق: الثقافة السياسية في مصر بين الاستمرارية والتغيير، القاهرة، مركز البحوث

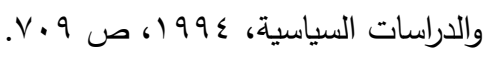

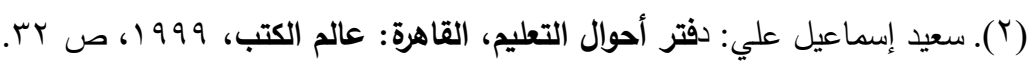


هذا بالإضافة إلى أن دور الجامعة يمتد ليشمل عملية التنمية السياسية، فهي مصدر لنشر الثقافة السياسية وتعلم ما يظهر من خلالها من خبرات، وتكوين الوعي السياسي لدى الثيته الثباب الجامعي. ومن المعلوم أن أثر التعليم في رفع مستوى الوعي السياسي للفرد يزداد في مراحل التعليم العليا

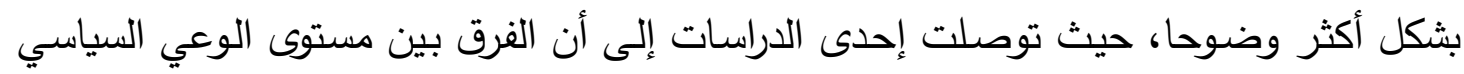

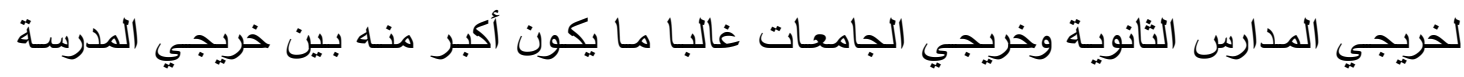

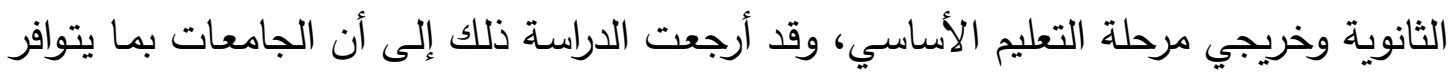

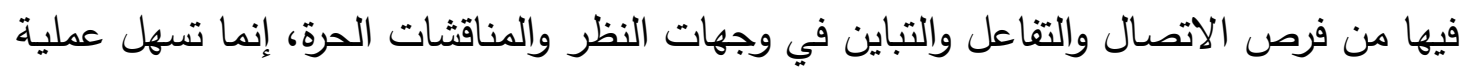

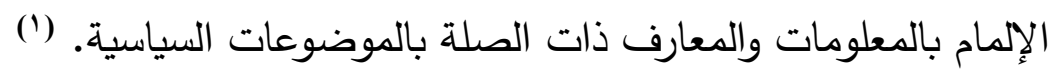
مشكلة البحث: تعد المرحلة الجامعية من أهمّ المراحل التي مر بها المتعلم بوصفها مرحلة النضوج

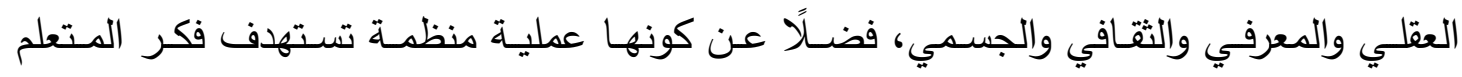

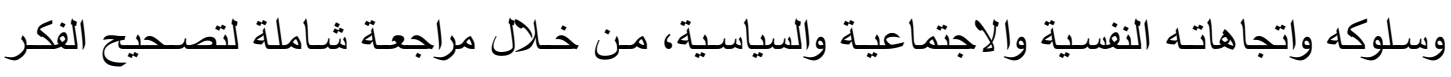

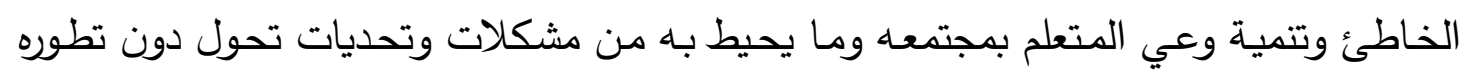

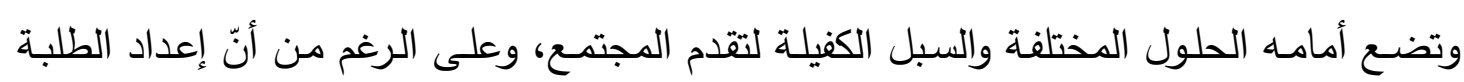

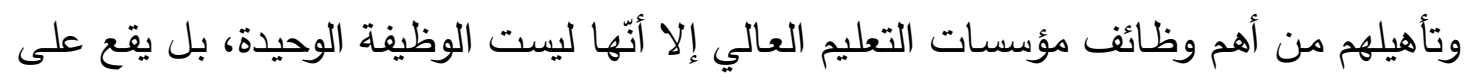

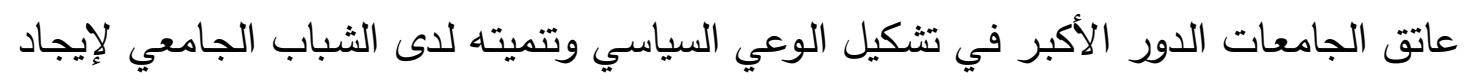

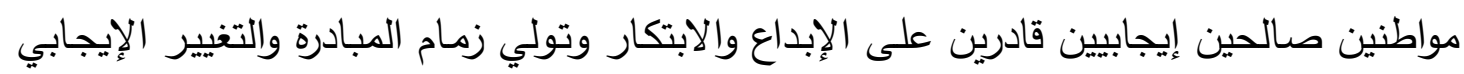

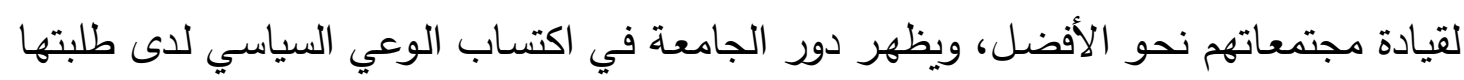

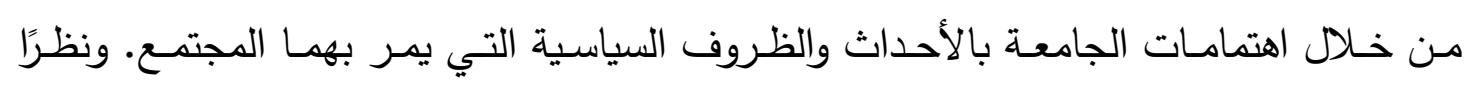
لأهمية دور الجامعات في تثكيل الوعي السياسي وتتميته لدى طلبتها عامة والطلاب الكويتين

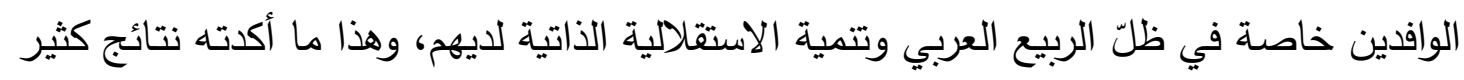

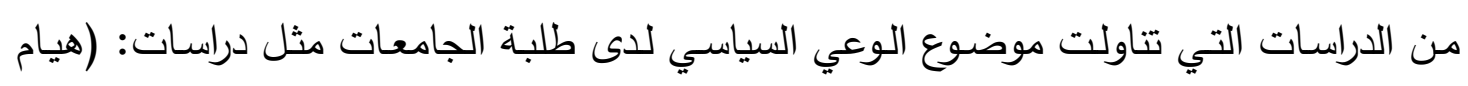

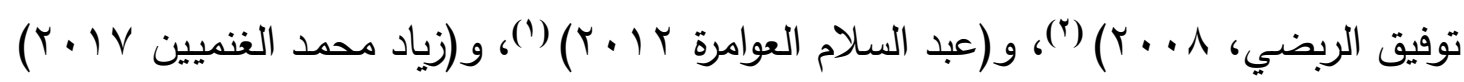

(1). حنان لمراني العلوي: دور المدرسة في تنمية الوعي السياسي لطلاب التعليم الثانوي العام بمحافظة غزة (دراسـة

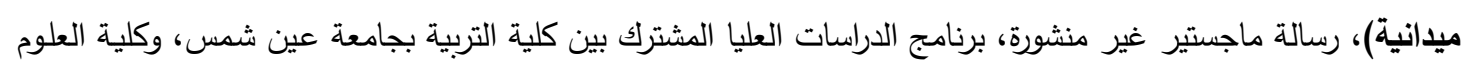

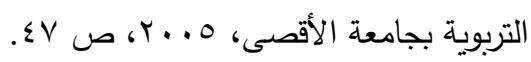

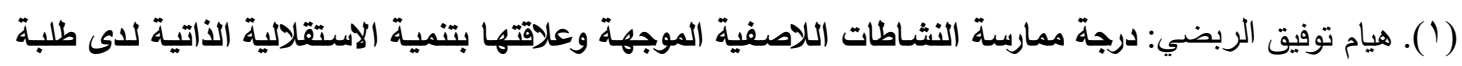

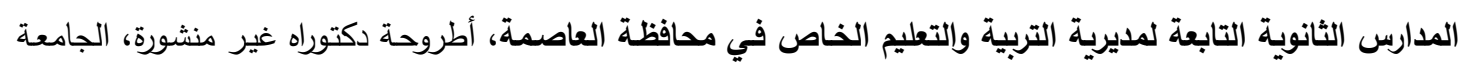

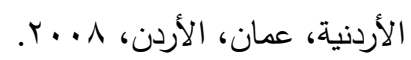


(†)، وغيرها من الدراسات والتي اشارت في نتائجها الى أن دراسـة الطالب في الجامعة تساعد على تكريس الوعي بالواجبات تجاه الوطن واعتمـاد الطلبة على أنفسهم في القيات ولفيام بواجباتهم الجامعية مما يؤدي إلى الابتعاد عن الفوضى في سلوكهم والالتزام بالقوانين السائدة في المجتمع.

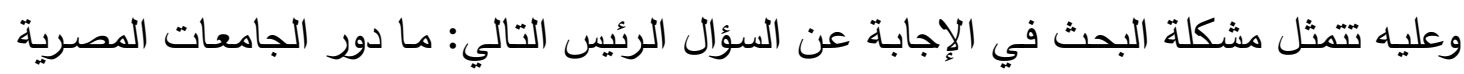
في تنمية الوعي السياسي لدى الطلاب الكويتين؟ وبشكل أكثر تحديدًا حاول البحث الإجابة على الأسئلة البحثية التالية:

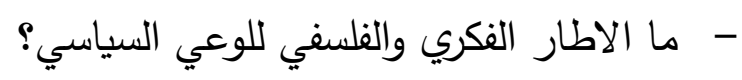

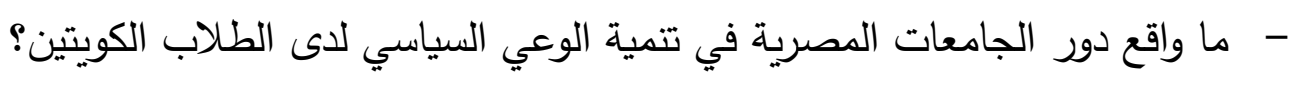

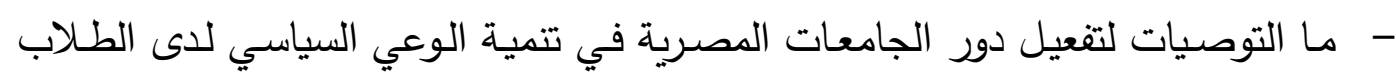
الكويتين! أهداف البحث:

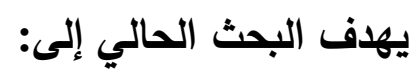

- التعرف على دور الجامعات المصرية في تتمية الوعي السياسي لدى الطلاب الكويتين

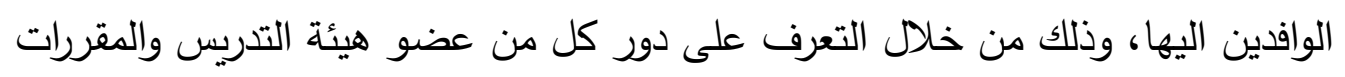

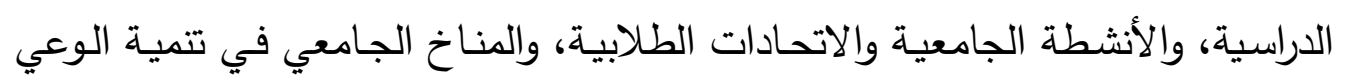
السياسي للطلاب. - - وضـع بعـض التوصـيات الملائكـة لتتميــة الـوعي السياسـي لـدى الطـلاب الكـويتين بالجامعات المصرية.

تنبع أهمية البحث من أهمية دور الجامعات في تكوين شخصية الفرد وصقلها وتنمية

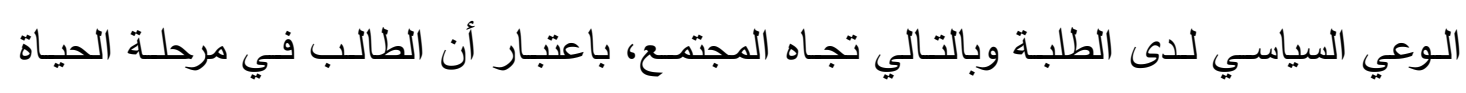

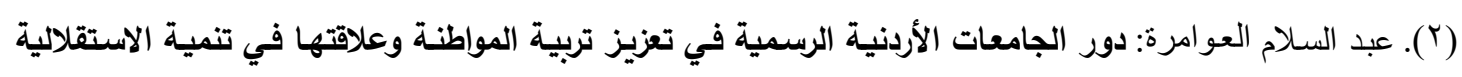

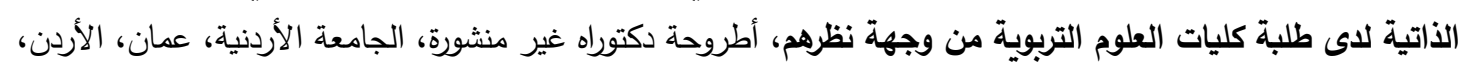

(r). زياد محمد الغنيمين: دور إذاعة الجامعة الأردنية في تنمية الوعي السياسي لاى طلبة الجامعة الأرنية، مجلة

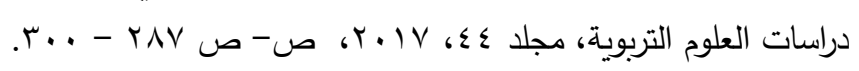


الجامعية تكون لديه قابلية أكثر لاكتساب قيم ومفاهيم واضحة عن البيئة السياسية التي يعيش

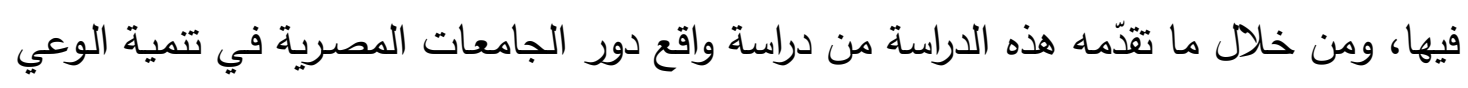

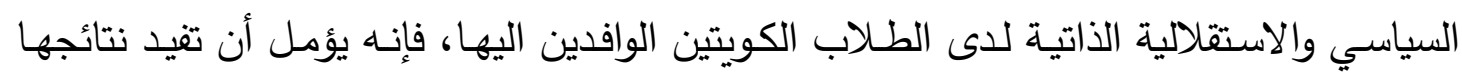

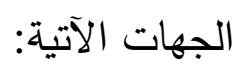

- - وزارة التعليم العالي والبحث العلمي في مصر للإفادة من واقع دور الجامعات في تتمية الوعي السياسي، والتي تسهم في تتمية مفهوم الوعي السياسي للى الطلاب الكويتين

الوافدين في الجامعات المصرية، عند رسم السياسية التربوية.

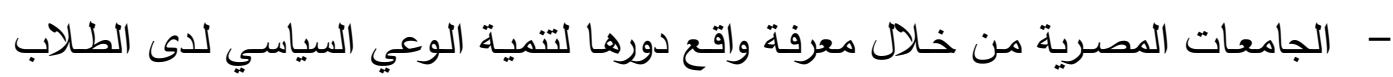

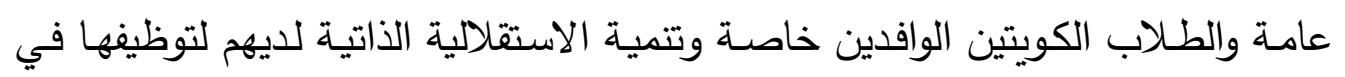

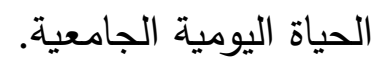

- - جاءت هذه الدراسة مواكبة للتطور الذي طرأ على النظام العالمي والاقليمي، واستجابة

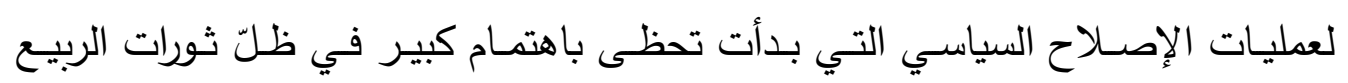
العربي. - - تعد هذه الدراسـة مـن الدراسـات الرائدة -حسب علم الباحثّة- التي تبحـث في دور

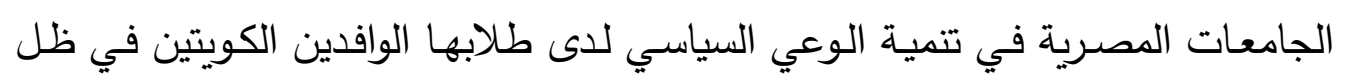

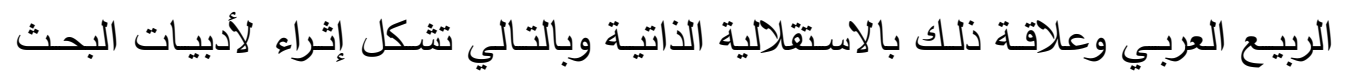
التربوي وإثراء للمكتبة العربية بشكل عام، والمكتبة المصرية بشكل خاص. باص.

\section{مصطاح الدراسة:}

\section{1 الوعي السياسي: Political Awareness} عرف الوعي السياسي أيضا بأنـه: معرفة المواطن لحقوقه السياسية، وواجباته وما يجرى حوله

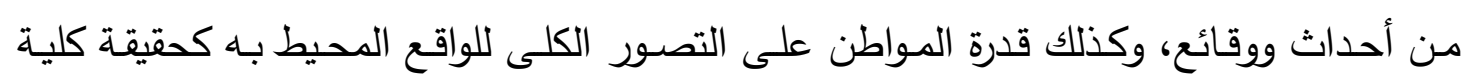

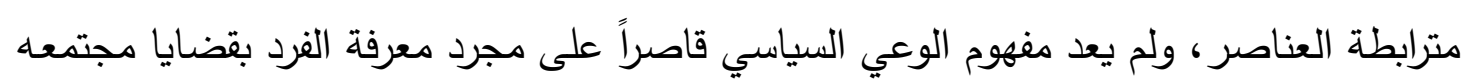

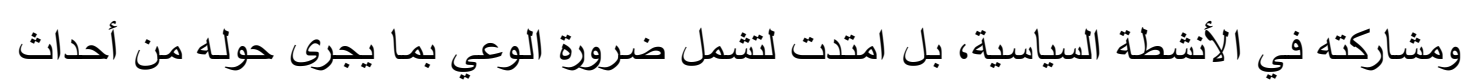

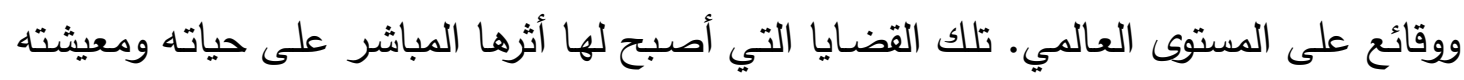

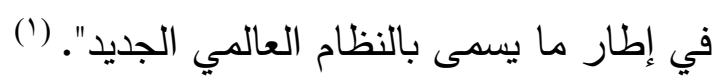

(1). عبد ربه، صابر: الاتجاهات النظرية في تفسير الوعي السياسي، الإسكندرية: دار الوفاء للنيا الطباعة والنشر، 
كما يعرف الوعي السياسي بأنه: عبارة عن الاتجاهات والمبادئ السياسية المتكونة للى الطلاب نتيجة للثقافة السياسية التي يحصلون عليها داخل المدرسة من خلال دراستهم للمناهج الدراسية التي تجعلهم فاعلين ومشاركين في قضايا مجتمعهم. (')

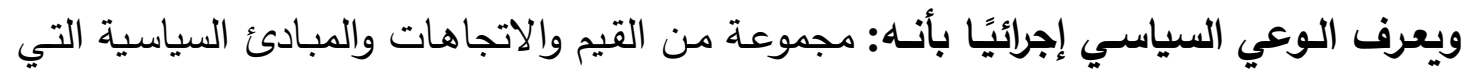

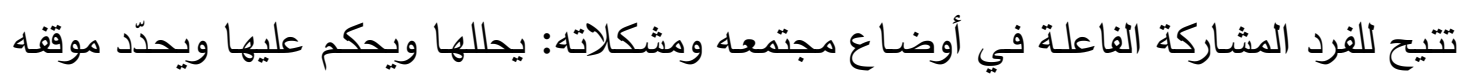
منها ويدفعه إلى التحرك من أجل تطويرها وتغييرها.

ץ- طلاب الجامعة الكويتين: Kuwaiti University Students - يعرف طلاب الجامعة الكويتين الوافدون بأنهم: هؤلاء الطلاب غير المصريين الذين جاؤوا إلى مصر بغرض الدراسة في الجامعات المصرية. دراسات وبحوث عربية وانجليزية سابقة: هناك العديد من الدراسات التي اهتمت بالتعرف على دور الجامعات في تتمية الوعي السياسي لاى طلابها، ويمكن عرض بعضها كما يلي:

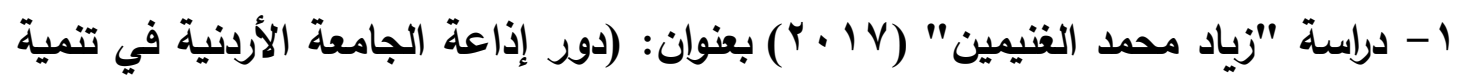

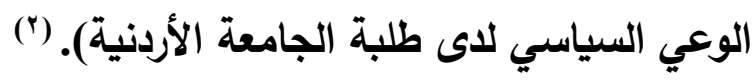

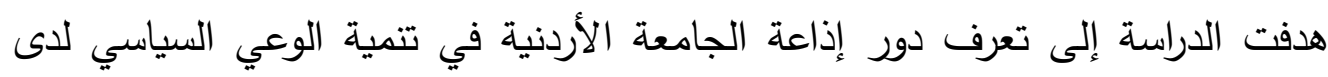
طلبة الجامعة الأردنية، وتكونت عينة الدراسة من (10 (0) طالباً وطالبة، وتم تطوير أداة للدراسة.

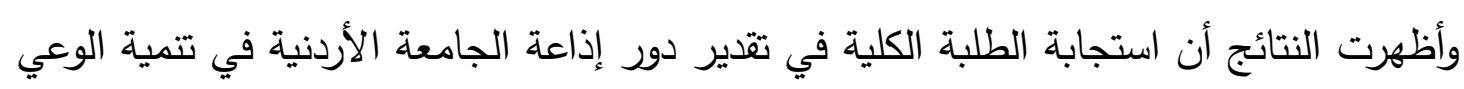

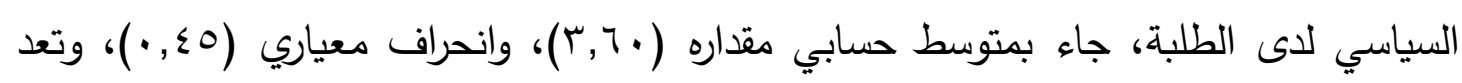

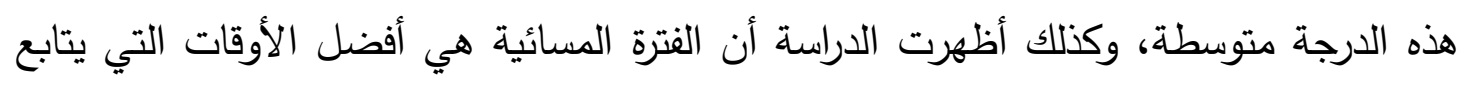

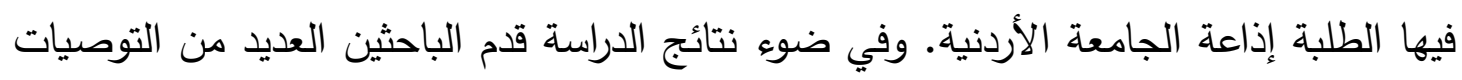

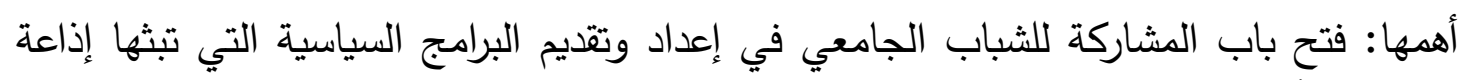
الجامعة الأردنية و الموجهة لهم.

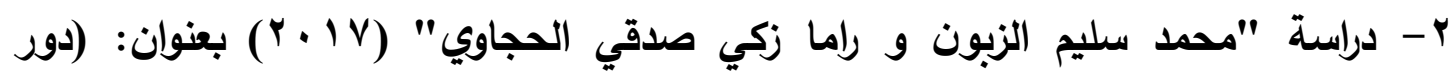

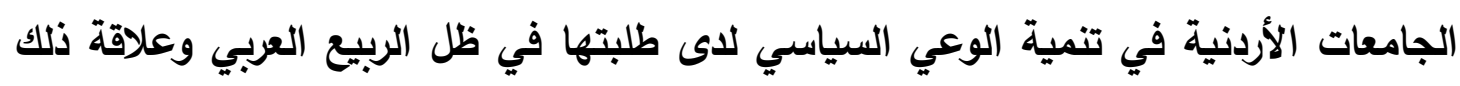

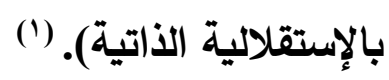

(r). مصطفي سيد إسماعيل: اثر منهج التاريخ على الوعي السياسي لاى تلاميذ الصف الثالث الإعدادي، رسالة

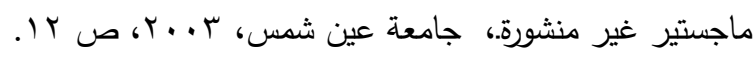

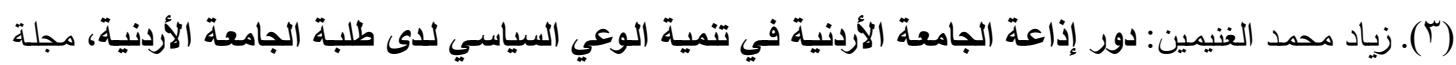

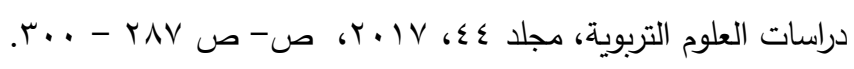


هدفت هذه الدراسة إلى معرفة واقع دور الجامعات الأردنية في تتمية الوعي السياسي

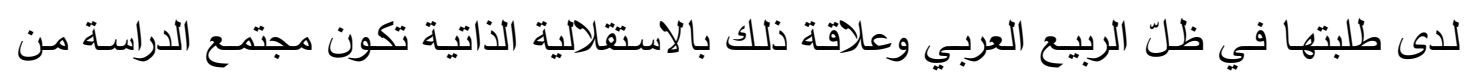

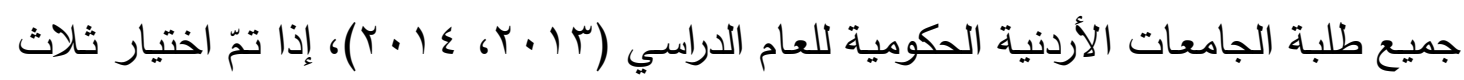

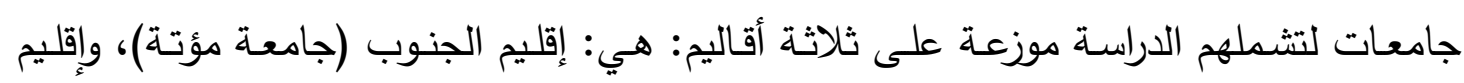

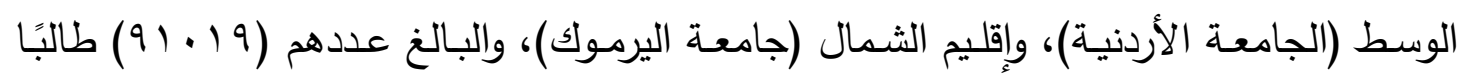

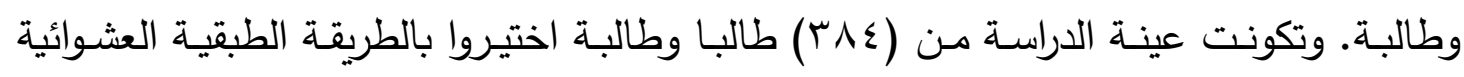

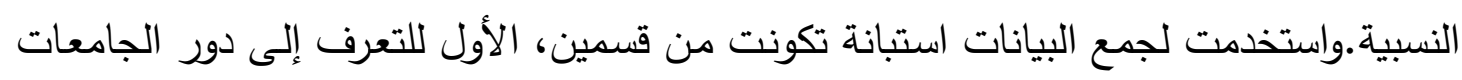
في تتمية الوعي السياسي، والثاني للتعرف على دور الجامعات في تتمية الاستقلالية الذاتية.

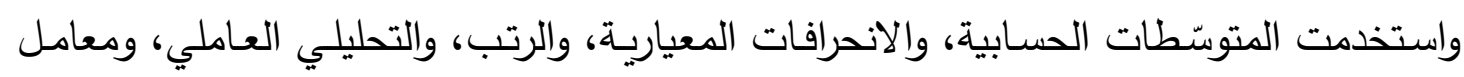

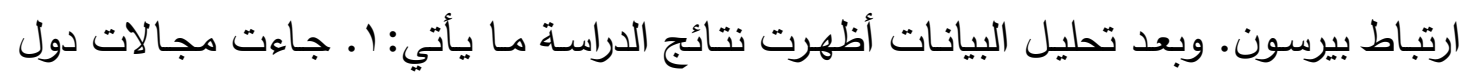

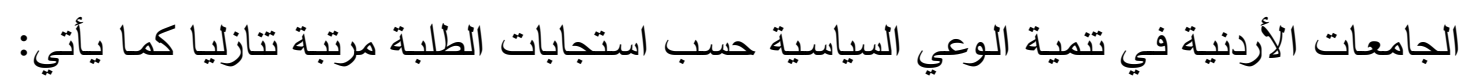

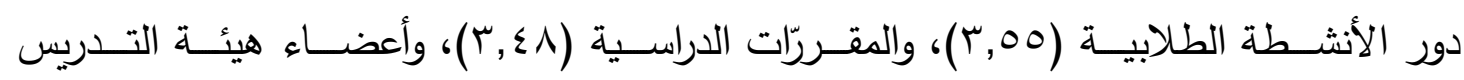

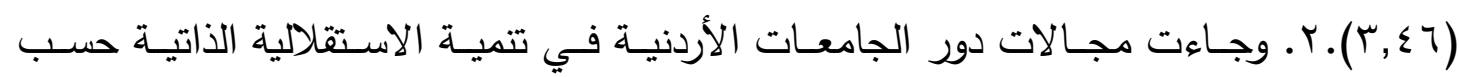

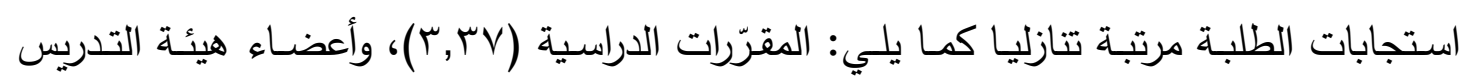

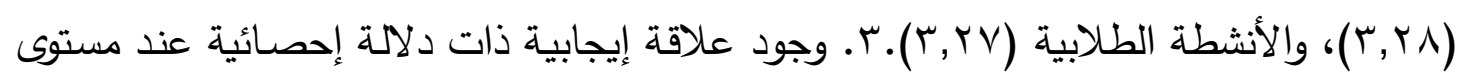

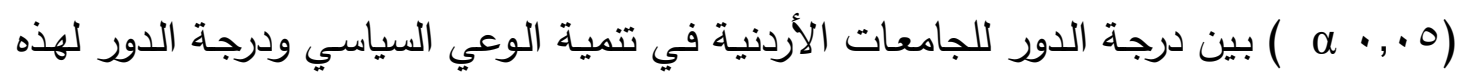

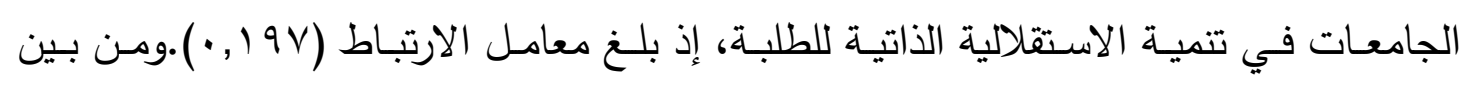

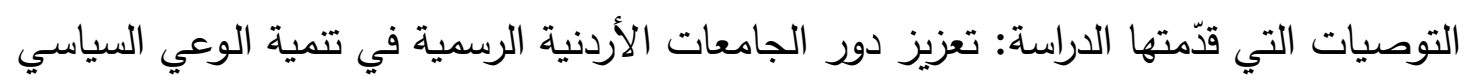
لاى طلبتها، بتضمين مادّة دراسية مناسبة في برنامج الطلبة.

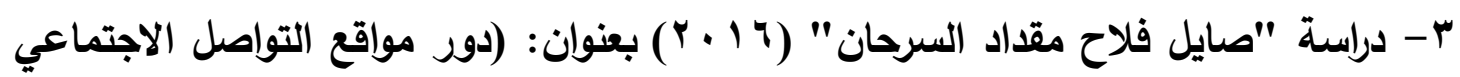

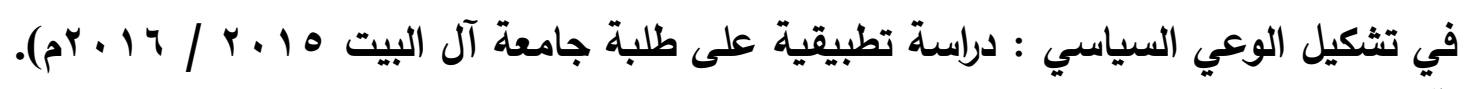

( (1). محمد سليم الزبون و راما زكي صدقي الحجاوي: دور الجامعات الأردنية في تنمية الوعي السياسي لاى طلبتها في

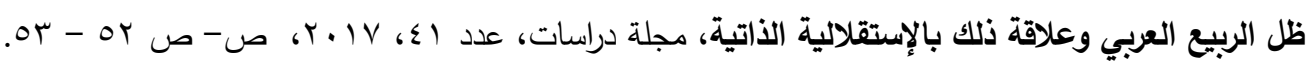

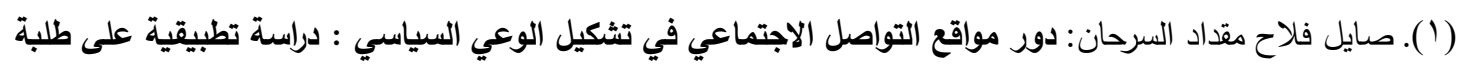

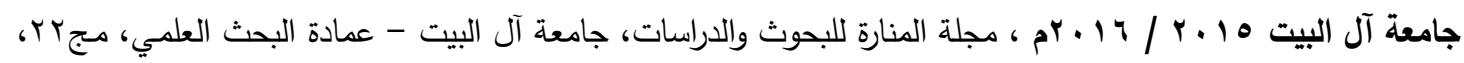

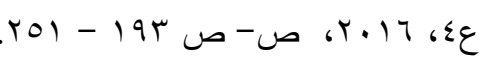


تمثل هذه الدراسة محاولة لتقصي دور مواقع التواصل الاجتماعي في تشكيل الوعي

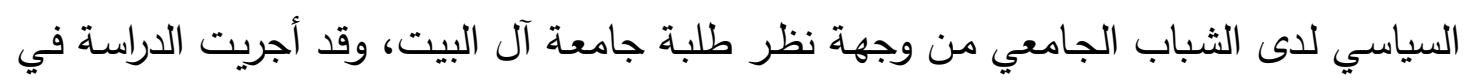

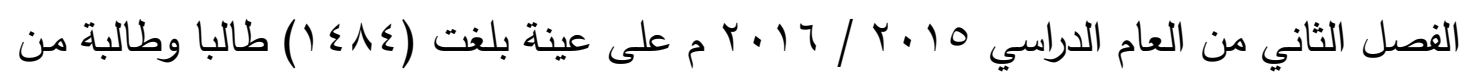

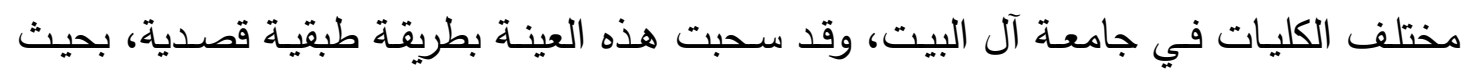

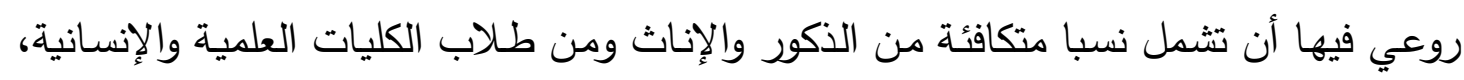

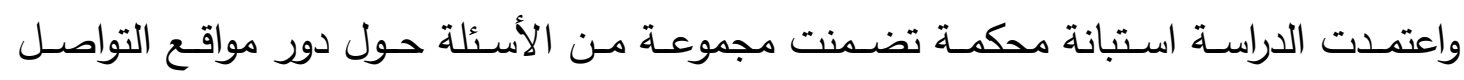

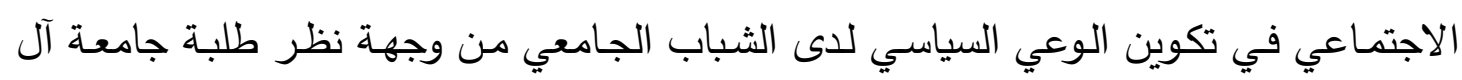

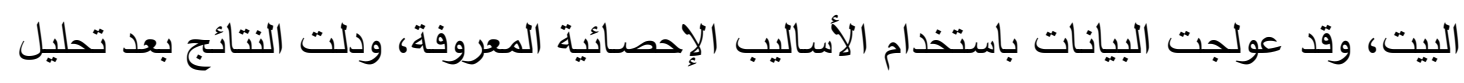

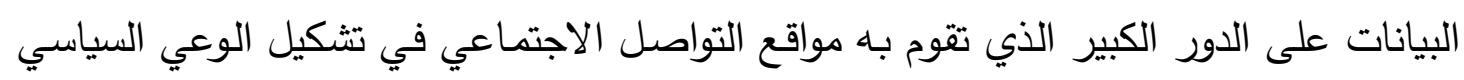

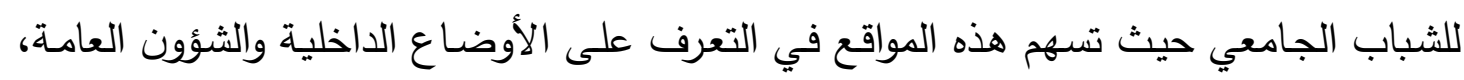

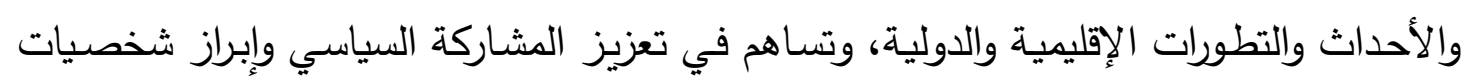

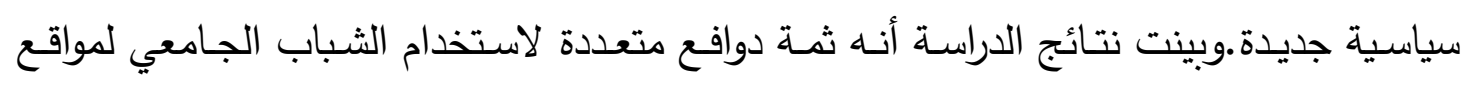

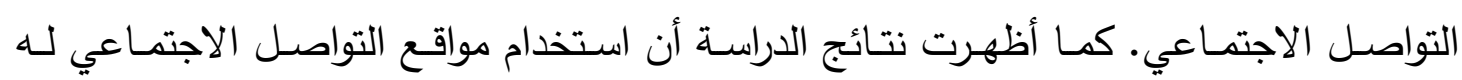
ايجابيات وسلبيات.

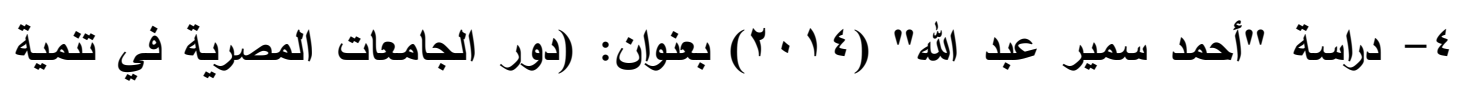

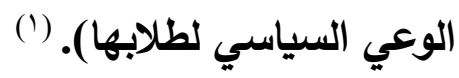

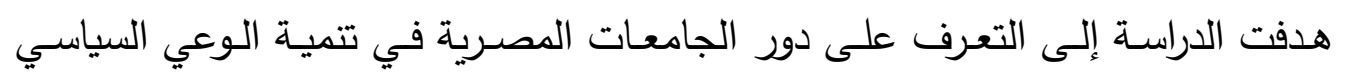

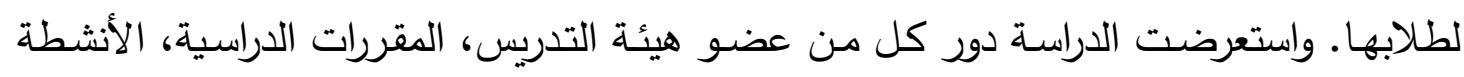

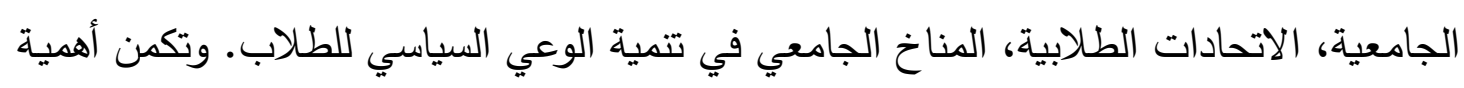

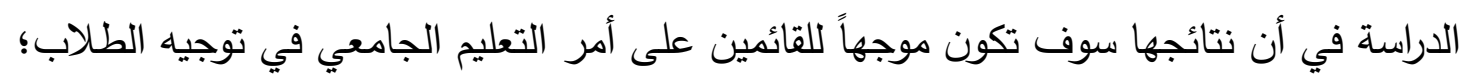

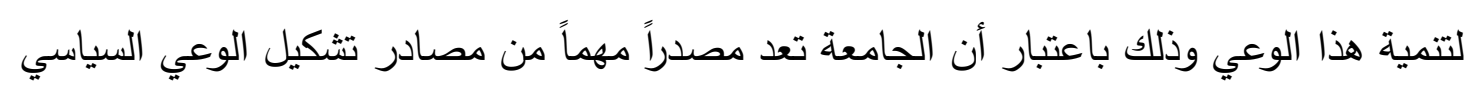

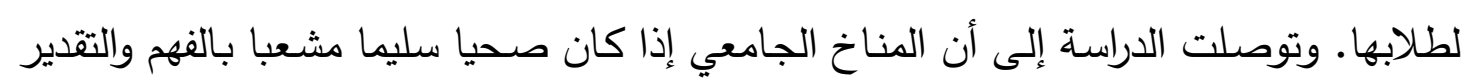

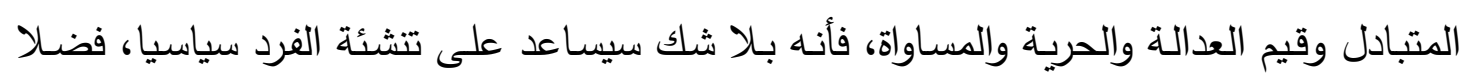
عن نمو شخصيات متكاملة ومتزنة ومتوافقة نفسيا. وأوصت الدراسة بضرورة تبني عضو هيئة

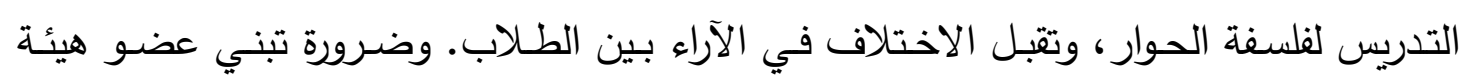
التدريس لطرق التدريس القائمسة على بعض استراتيجيات التعلم النشط كالتعلم الذاتي، التعلم

(Y). أحمد سمير عبد الله: دور الجامعات المصرية في تنمية الوعي السياسي لطلابها، مجلة التربية، دور الجامعات

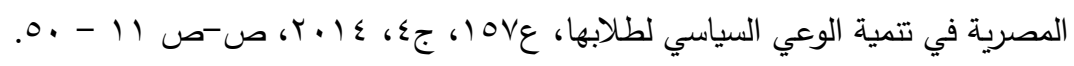




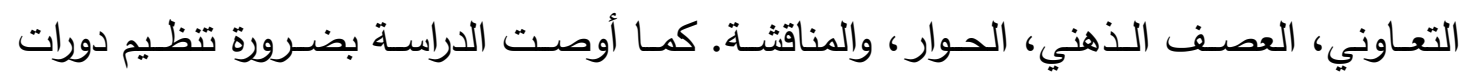
تدريبية؛ لرفع مستوى الوعي السياسي لاى أعضاء هيئة التدريس.

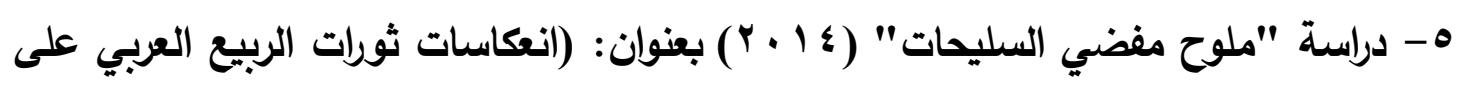

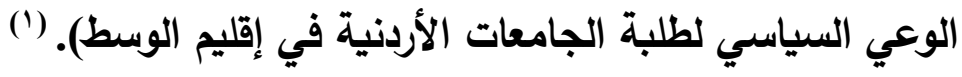

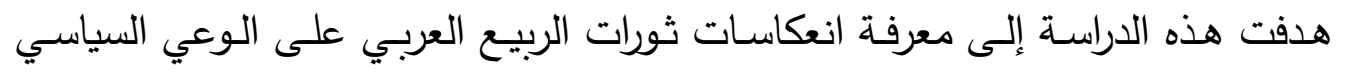

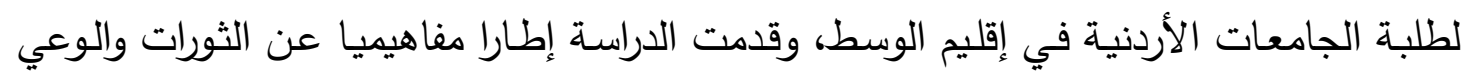

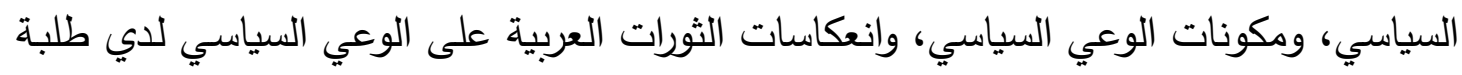

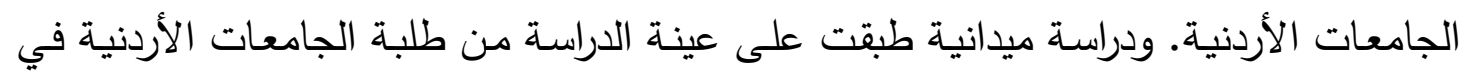

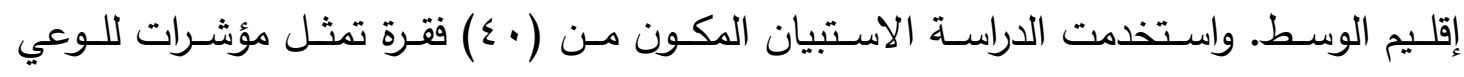
السياسي. وطبقت الأداة بعد أن تحقق لها صدق وثبات مقبولين. وتم معالجة البيانات باستخدام المتوسطات الحسابية، والانحرافات المعيارية، والاختبارات الإحصائية المناسبة لأسئلة الدراسة الأسة

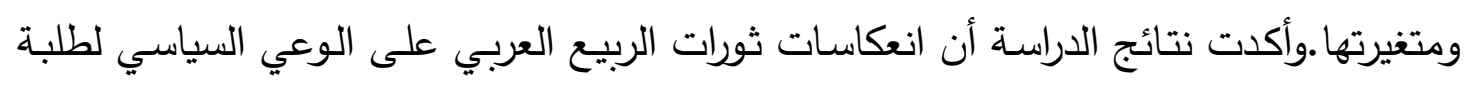

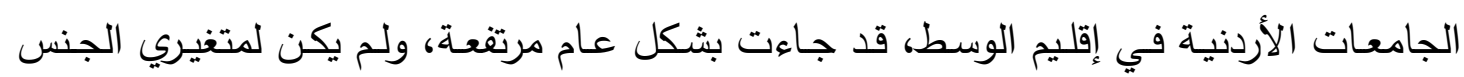

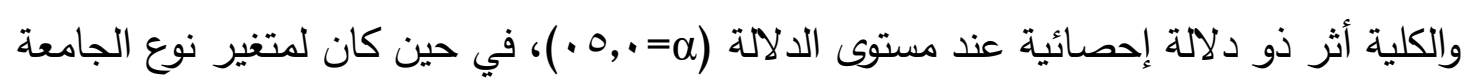

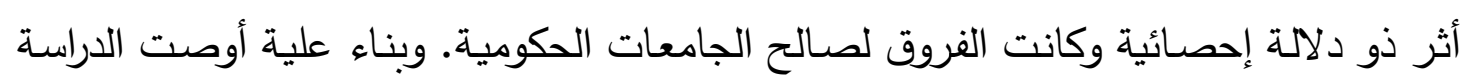

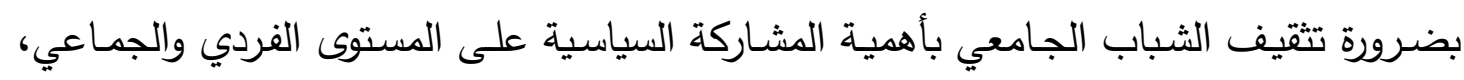

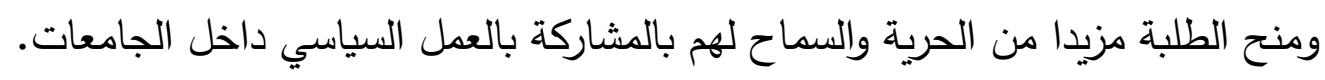

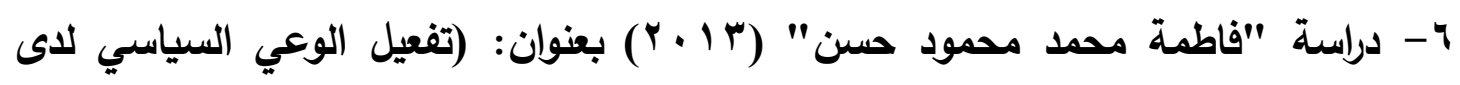

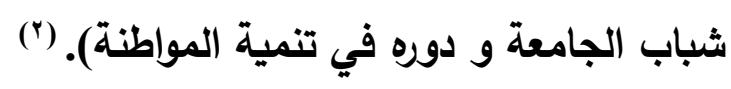
هدفت الدراسة إلى بيان كيفية تفعيل الوعي السياسي لدى شباب الجامعة ودوره في تتمية

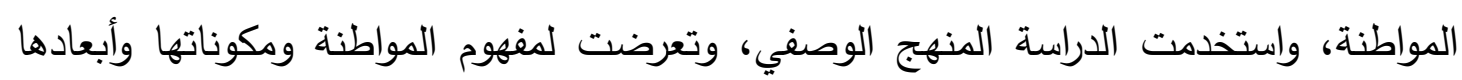

(1). ملوح مفضي السليحات: انعكاسات ثورات الربيع العربي على الوعي السياسي لطلبة الجامعات الأردنية في إقليم

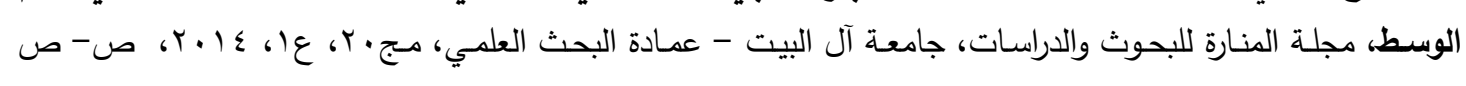
$r v v-r \leqslant 9$

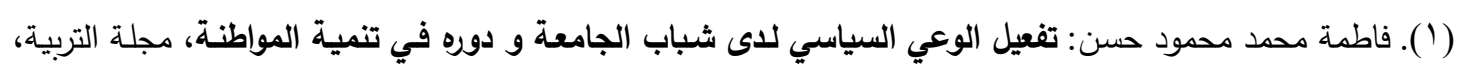

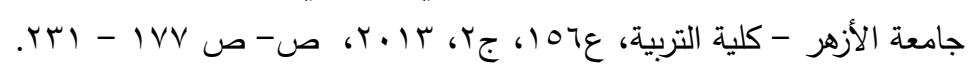


وعلاقتها بالتربية وعلاقة التربية بالوعي، ثم بينت المقصود بالوعي السياسي وأهميته وأبعاده

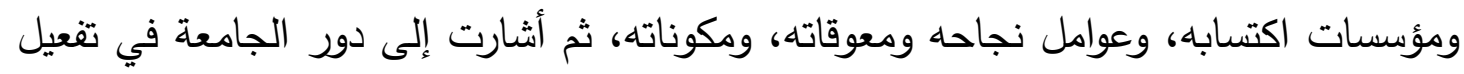

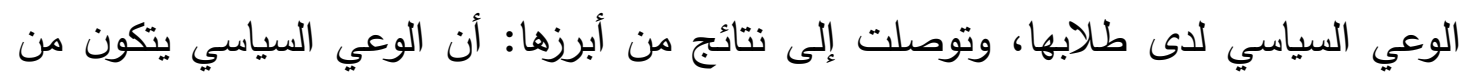

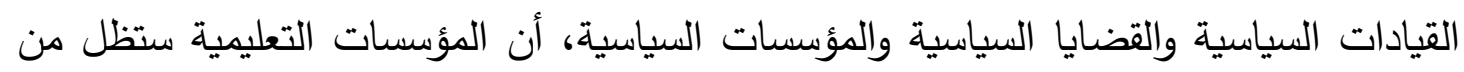

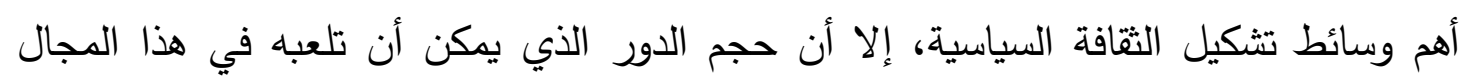
يتوقف على مدى توافر الظروف الداعمة لدورها، سواء كانت هذه الظروف تتعلق بالبيئة الداخلية للمؤسسات التعليمية نفسها، أو تتعلق بالظروف المجتمعية المحيطة بها، أن الجامعة بما تملكه

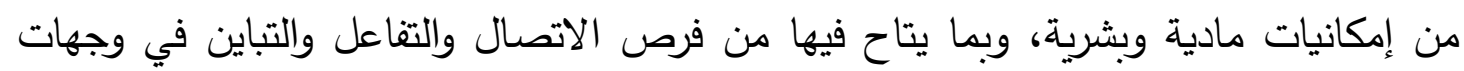

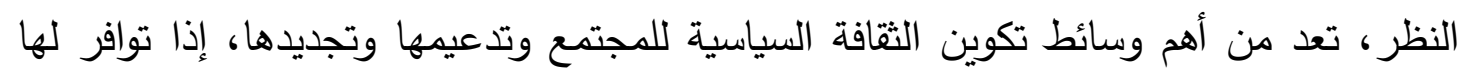

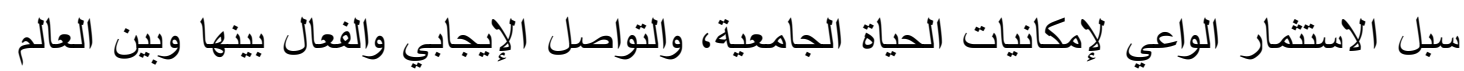
المحيط بها.

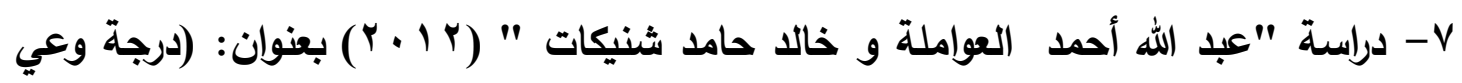

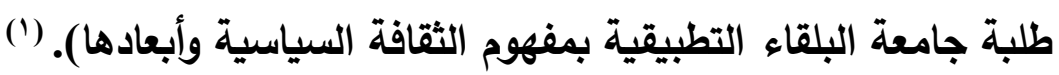

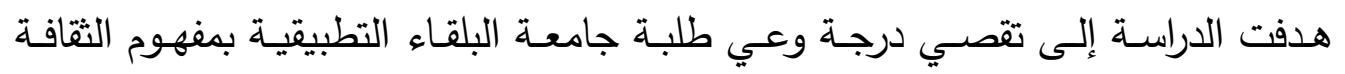

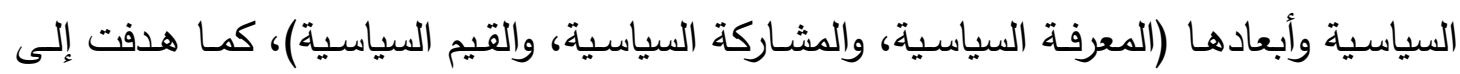

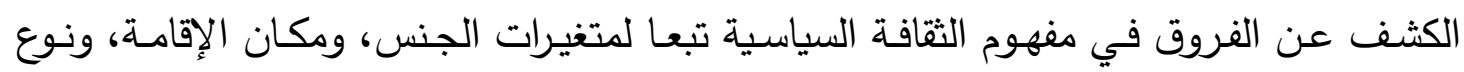

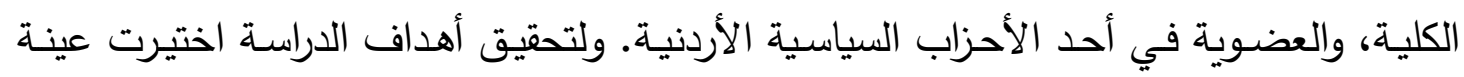

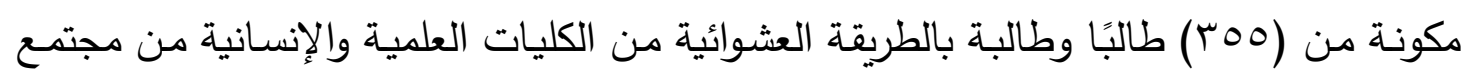

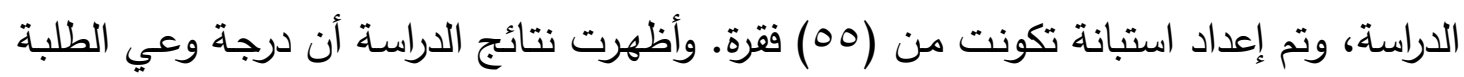

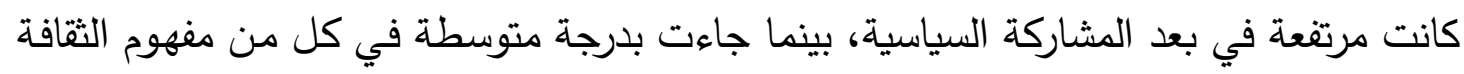

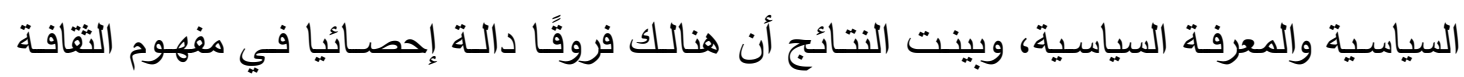

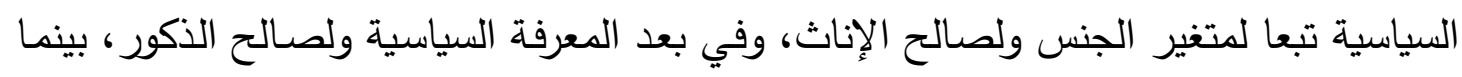

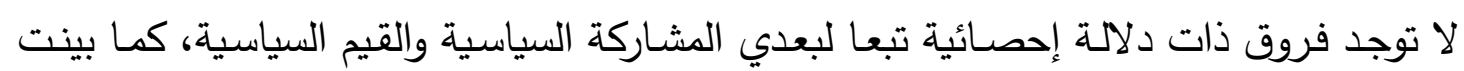

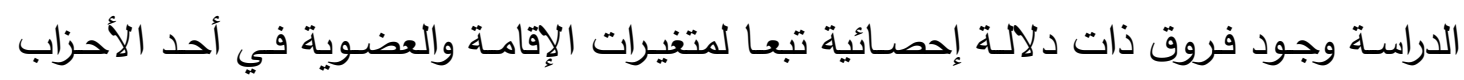
السياسية، وأظهرت النتائج عدم وجود فروق ذات دات دلاتلة دالة إحصائية تبعًا لمتغير نوع الكلية.

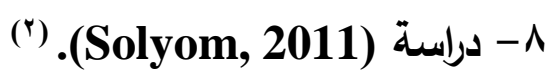

(r). عبد الله أحد العواملة و خالد حامد شنيكات: درجة وعي طلبة جامعة البلقاء التطبيقة بمفهوم الثقافة السياسية

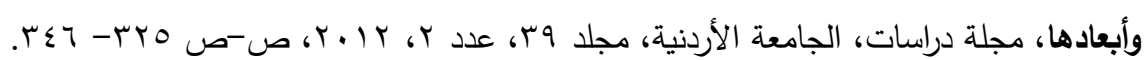
(1). Solyom, A; "High school and university student's opinions about politics," Journal of Comparative Research in Anthropology and Sociology, 2(1), 2011,173. 
هدفت الدراسة الى الكثف عن دور الجامعة في تتمية الوعي السياسي لدى طلابها،

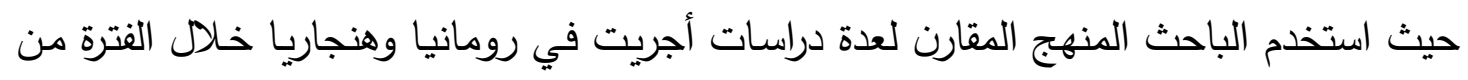

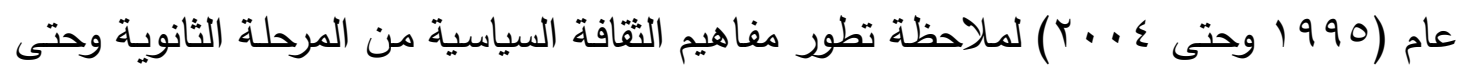
نهاية التعليم الجامعي حسب متغيرات (العمر - السنة الدراسية- المستوى الاقتصادي للعائلة-

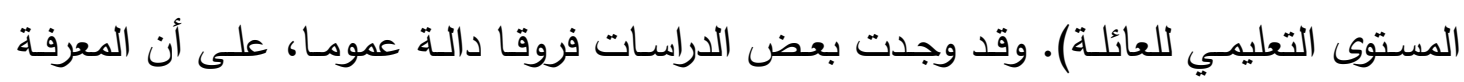

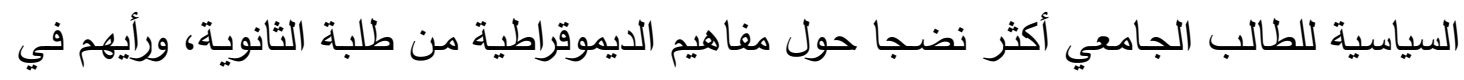
سياسات الدولة أكثر وعيًا، وأن هنالك اختلافات كبيرة حول رأي الطلبة في رومانيا عن هنجاريا

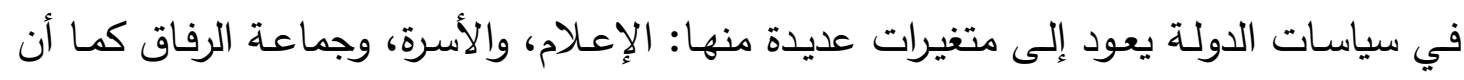

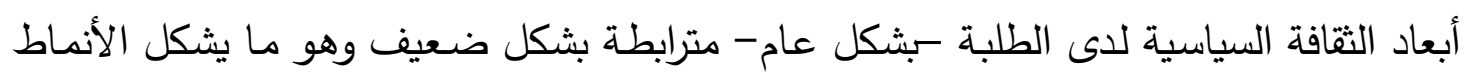
المختلفة للثقافة السياسية عند الطلبة والتي تتبلور أكثر في المستوى الجامعي.

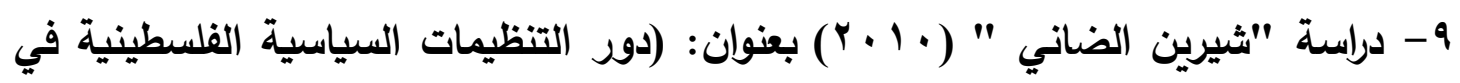

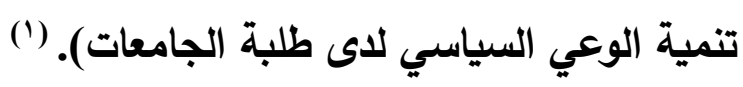

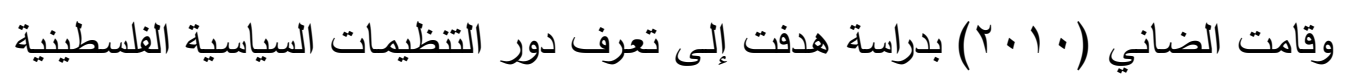
في تتمية الوعي السياسي للى طلبة الجامعات في قطاع غزة، وذلك من خـال إجراء دراسة

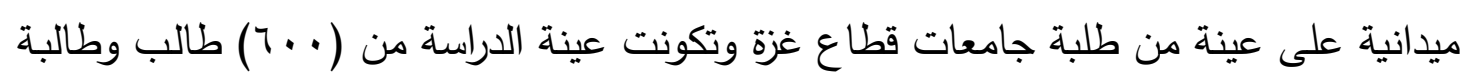
أجابوا عن بعض التساؤلات التي تضمنت الكثف عن عن مستوى الوعي السياسي لديهم نحو المعرفة

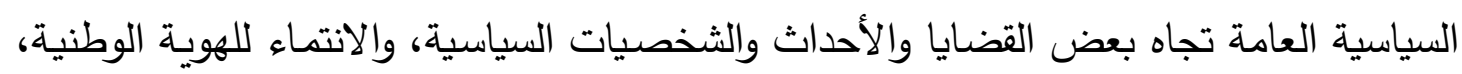

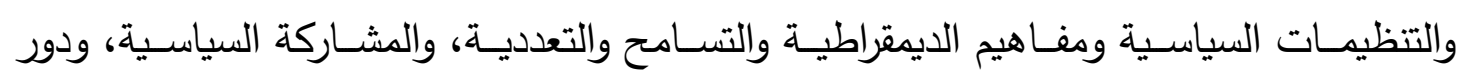

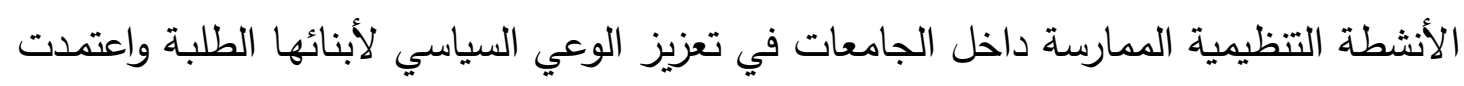

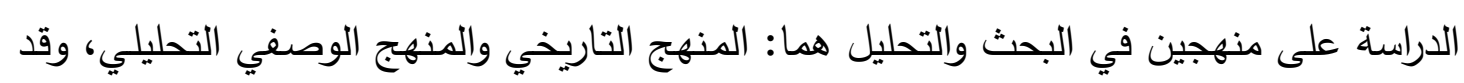

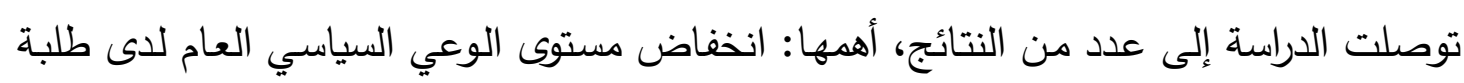

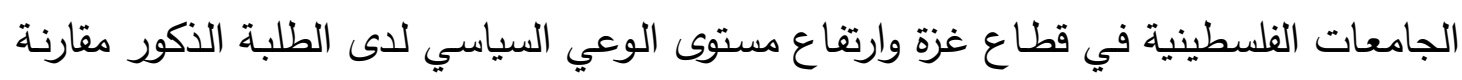

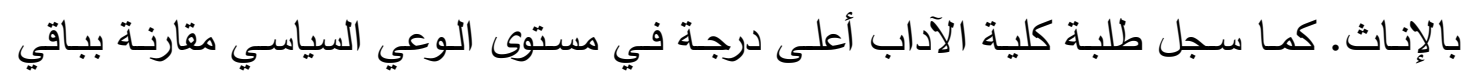

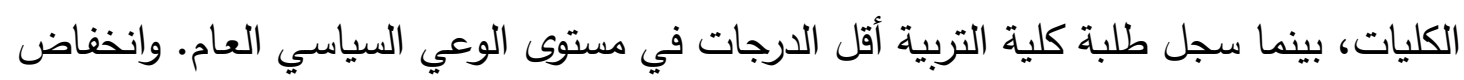

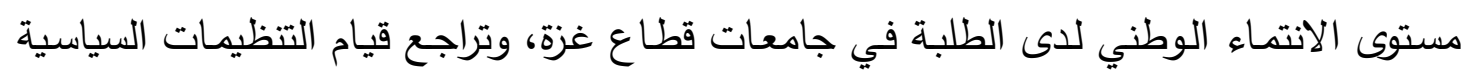
بالجامعة بوظائفها التوعوية في تعزيز الانتماء، وبلورة الهوية الوطنية ونشر الوعي السياسي الوني.

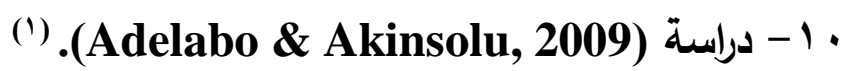

(r). شيرين الضـاني: دور التظظيمـات السياسية الفلسطينية في تنميـة الوعي السياسـي للاى طلبة الجامعات، رسالة

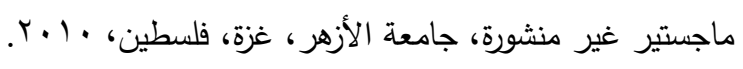


هدفت الدراسـة إلى معرفة دور الجامعات النيجيريـة في التثقيف السياسي لطلبتها من خـلال المنـاهج، والإعـام الجـامعي، وجماعـة الرفاق، والمحاضـرات. ومعرفـة العوامـل الطبيعيـة والاجتماعية والسياسية التي يمارسها الطلبة داخل الجامعة وتسليط الضـوء على العامل الأهم المؤثر في الثقافة السياسية التي تقوم بها الجامعة لطلبتها وتكونت العينـة من ( . . ( ) طالب

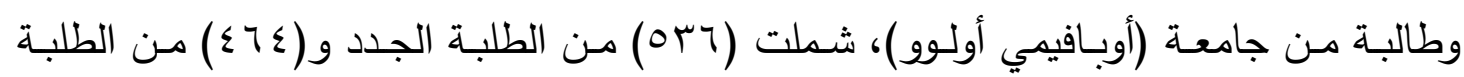
القدامى. وقد أظهرت نتائج الدراسـة أن الطلبـة يتأثرون بالتعليم السياسي الذي تقدمـه الجامعـة وكان التأثير في الطالب القديم أكثر من التأثير في الطالب الجديد، وأن هناك فروقا ذات دلالة إحصائية لتأثير التعليم السياسي الجامعي في الذكور أكثر من الإناث والعامل الأكثر تأثيرا في ثقافة الطلبة السياسية كان على الترتيب المناهج، فاتحاد الطلبة، فالمحاضرات.

() .Angelique \& Reischl, 2002) (1)

هدفت دراسة أنجليكو وريشال (Angelique \& Reischl, 2002) التعرف إلى دور الجامعات في تمكين الطلبة على المستوى السياسي والإسهام في تشكيل السياسة العامة للدولة، وآليات إدماج الشباب ومشاركتهم في تتمية المجتمع، وتكونت عينة الدراسة من (ج • ( ) طلاب وطالبات من إحدى الجامعات الأمريكية، واستخدم المنهج التجريبي إذ تم تقسيم عينة الدراسة إلى

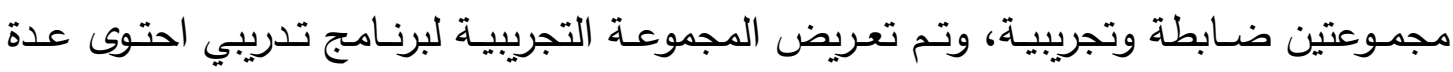
جوانـب منهـا حـل النزاعـات، والثقافـة السياسية والتعامل مـع المجتمـع المحلي، ثـم تمّ تعريض المجموعتين لمواقف ذات صلة بالمشكلات الحياتية وقضايا وثيقة بالعمل السياسي، وقد خلصت الدراسة إلى وجود فروق ذات دلالة إحصائية بين المجموعتين ولصالح المجموعة التجرببية، مما يؤكد أهمية الجامعة ومكانها ودورها في تتمية الوعي السياسي وتمكينه لدى الطلبة. كما أجرى بارتون (Barton, 2004) دراسة استطلاعية هدفت لتقديم خطة عمل لكلية بيريا (Berea) في ولايـة كنتاكي الأمريكيـة لزيـادة فاعليـة الطلبـة في المشـاركة في الانتخابـات الرئاسية الأمريكيـة والمشـاركة السياسية والاجتماعيـة للطلبـة في المجتمع . وقد وزعت استبانة على (TV) طالبًا وطالبة في كلية بيريا وقد وجد أنّ (7^^\%) من الطلبة مرتبطون سياسيا في العملية الانتخابية،

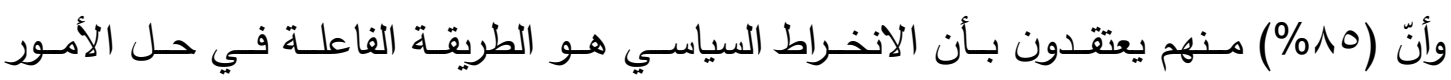

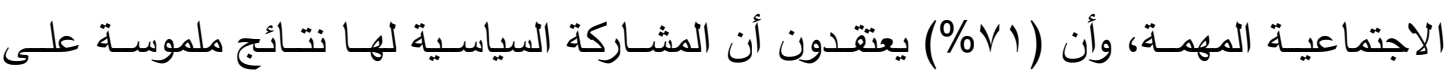
المجتمع، وأن كل (7 طلبة من · () يتوقعون أن تكون لهم مشاركة سياسية أكبر من ذويهـ،

(1). Adelabu, M.A. \&Akinsolu,A.O; "Political education through the university : A survey of Nigerian university students," African Jornal of Political Science and international Relations, 3 (2), 2009, 46-55.

(2). Angelique \& Reischl; "Political empowerment evaluations of an intervention with university students," American Journal of Community Psychology, 30(6), 2002, 815-823.. 
وأظهرت النتائج أن العمل التطوعي لخدمة المجتمع يكون أكثر فاعلية وإقبالا عندما تعقد الكلية ورش عمل أو محاضـرات تدريبية حول أهمية العمل التطوعي للمجتمع مقارنة بالعمل التطوعي للحمات السياسية.

\section{الاطار المفاهيمي للبحث:}

يتناول الإطار المفاهيمي النظري للدراسـة بعضـا من الجوانب التي تتمثل في: محوين

اثنين اولهما: الوعي السياسي من حيث مفهوم الوعي السياسي، ومستويات الوعي السياسي، ومصادر تشكيل الوعي السياسي، وثانيهما دور الجامعة في تتمية الوعي السياسي لطلابها من خـلال البحث والتدقيق في دور كل من عضد هيئة التدري، والمقررات الجامعيـة، والأنشطة الجامعية والاتحادات الطلابية، والمناخ الجامعي في تتمية ذلك الوعي ويختتم الإطار النظري للدراســة بوضـع مجموعـة مـن التوصـيات اللازمــة لتتميـة الـوعي السياسـي للطـلاب الكـويتين بالجامعات المصرية.

\section{المحور الأول: الوعي السياسي ا - مفهوم الوعي السياسي}

ارتبط الوعي السياسي وقضـاياه بالإنسـان المعاصر كثيراً حتى تم وصفه بأنـه " إنسان سياسي وأن عالمه عالم سياسي، ويأتي الوعي السياسي عادة نتيجة عدة عوامل مترابطة بعضها مع بعض كقراءة الكتب والاهتمام بالموضوعات السياسية والإلمام بالقضايا المرتبطة بالبلاد، كما تؤكد دراسـات أخرى على دور التشـئة السياسية وحجم المعلومات والمعارف التي يتعرض لها الفرد وأثر ذلك على زيادة درجة الوعي لديه (')، كما أشارت نتائج العديد من الدراسات إلى وجود

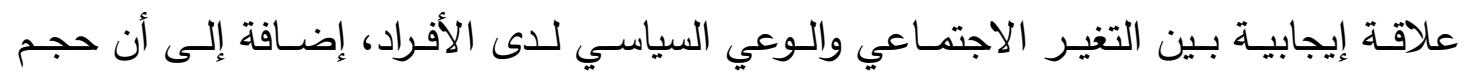
الإحباطسات المستمرة التي يشعر بها الأفراد هي أحد الأسباب في دفع الفرد للاهتمـام بشؤون (י) السياسة. (ن) ولا يقف الوعي السياسي عند مجرد قراءة ومتابعة القضايا السياسية، بل يتجاوز ذلك إلى سلوك وعادة يمارسه الفرد تلقائياً ليساهم بشكل عملي في تقديم حلول مشكلات مجتمعه، كما أن غياب الوعي السياسي هو ضعف في استقراء اتجاهات الأحداث في العالم، واحتمالية الوقوع في تحقيق أهداف ومخططات لجهات معادية لثقافة وهويـة الوطن، كما أن ضعف الوعي السياسي

(1). Buehler, Susan; "nterpreting political message, political awareness and back ground knowledge among young voters, political science general, Vol 65, 2005.

(1). سلوى العامري: الثباب وقضايا السياسة، الواقع والرؤى المستقبلية، المجلة الاجتماعية القومية، المركز القومي

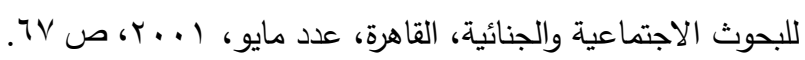


يقود للوقوع في فخ الاختراق السياسي والفكري للفرد مما يهدد مصلحة الوطن وسلامة مواطنيه.

فالوعي السياسي يعد حالة ذهنية تتمثل في إدرالك الإنسان للعالم على نحو عقلي أو

وجداني، وتأسيساً على هذا يتجلى الوعي الإنساني في صور شتى تتباين بتباين المجال المدرك

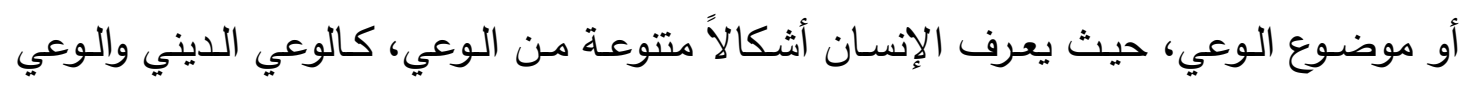

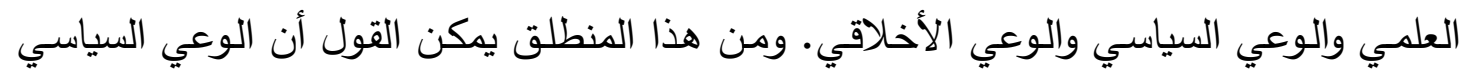

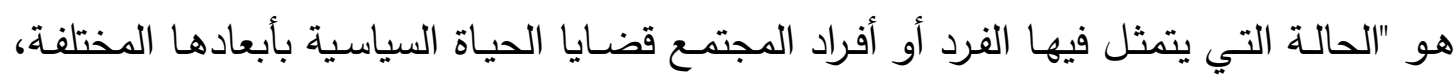

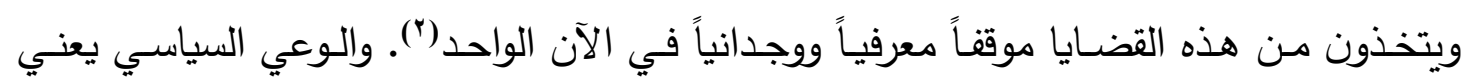

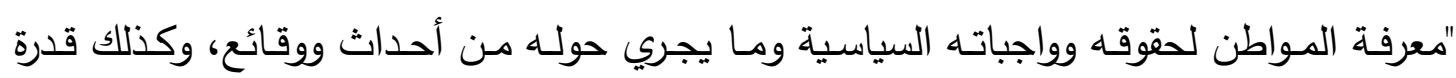
المواطن على التصور الكلي للواقع المحيط به كحقيقة كلية ومترابطة، وليست أحداث منفصلة ولهية

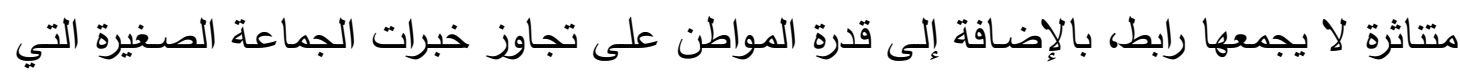
ينتمي إليها، ليعانق خبرات ومشكلات المجتمع الكلية".

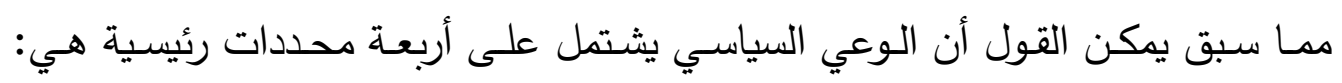

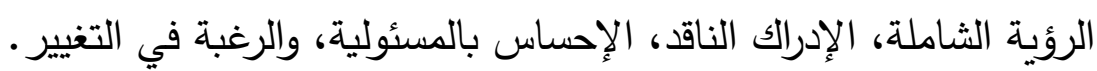

r - مستويات الوعي السياسي للوعي السياسي مستويين اثثين هما: الأول: مستوى الوعي النظري: أن مستوى الوعي النظري هو عبارة عن مستوى الأفكار والأيديولوجيات التي يحويها

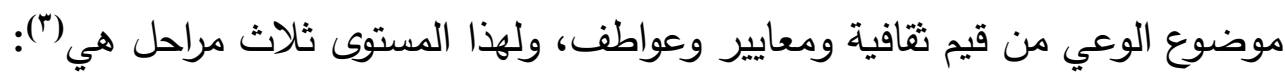

(Y). محمود عساف: الدور التربوي لمجالس طلبة الجامعات الفلسطينية في تثكيل الوعي السياسي وسبل تفعيله، مجلة

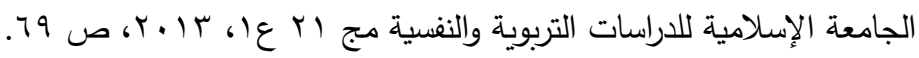

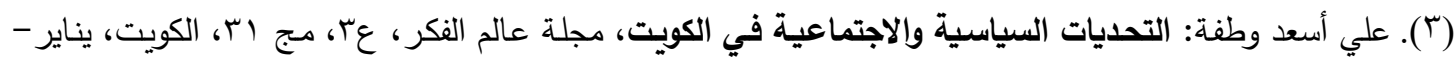

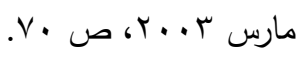
(1). عربي عبد العزيز الطوخي: دور مجلات الأطفال في التتشئة السياسية للطفل المصري، رسالة دكتوراه غير منشورة، معهد الدراسات العليا للطفولة، جامعة عين شمس، 999 19، ص صري 
مرحلـة المعرفـة والإدراكك: حيث يكون الفرد على مستوى الإدراك المباشـر وفهم الحقائق دون

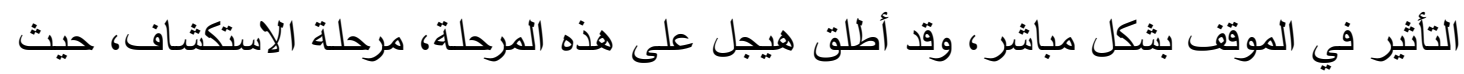
أنها بمثابة الاستعداد لتقبل الأفكار ثم حصرها وانتقائها. مرحلة الاهتمام السياسي: ويأتي ذلك الاهتمام من خلال الارتباط العاطفي بالجماعة والتهاء التي ينتمي

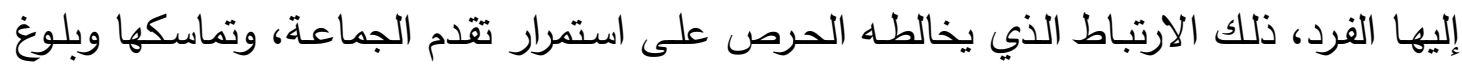

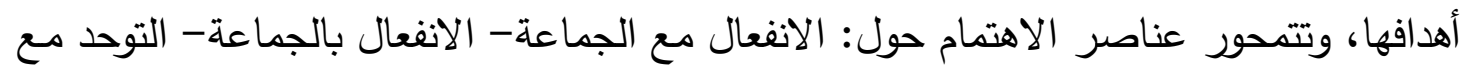

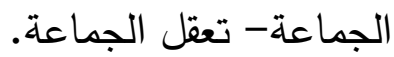

مرحلـة الانضـمام السياسـي: حيث يحتـاج الوعي إلى مؤسسة لتكوينـه فكريـا، والانضـمام لهذه

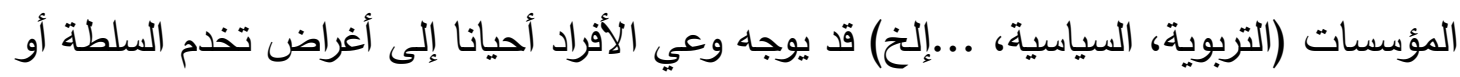
المؤسسة التي ينتمي إليها الفرد.

الثاني: مستوي الممارسة السياسية (المستوى العملي): لقد حدد "محمد أحمد خليفة" شروطا كي يتحقق دور الوعي في الممارسة السياسية منها (1) الثعور بالاقتدار السياسي: والاقتدار السياسي هو عبارة عن حالة ذهنية يشعر فيها الفرد بأنه يمتلك القدرة على فهم مواطن الصواب في النظام الاجتماعي العام فيؤازرها ويسعي لتتبيتها

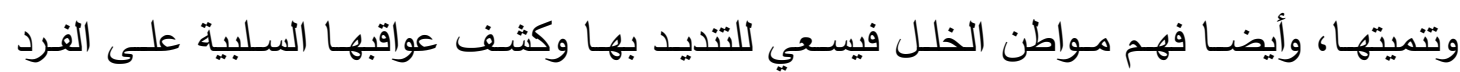
والجماعة، ثم يبدي رأيه دون خوف من لوم أو الو عتاب.

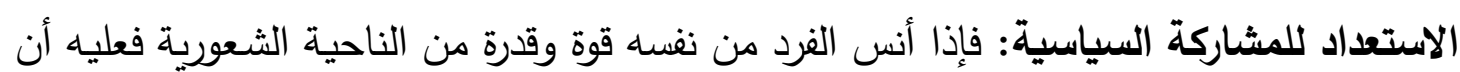

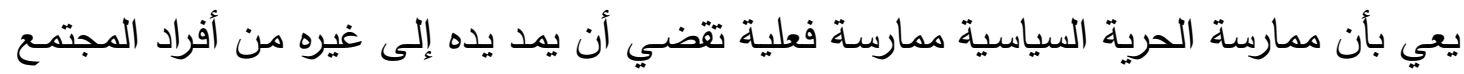

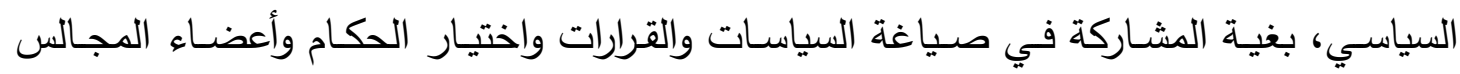
النيابية علي الصعيدين المحلي والمركزي. التسامح الفكري المتبادل: شريطة أن يكون النظام السياسي مرنا بحيث يسمح لكئ لكافة التوجهات

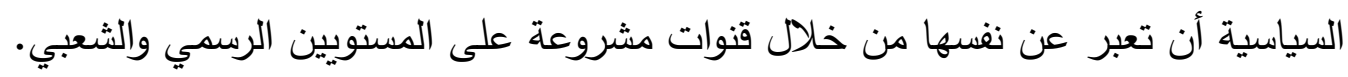

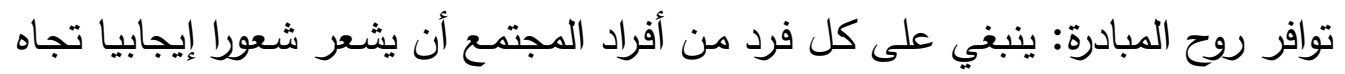

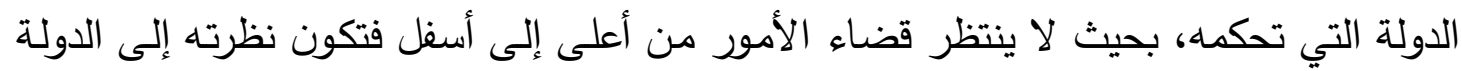

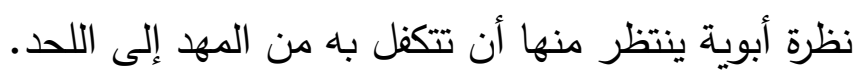

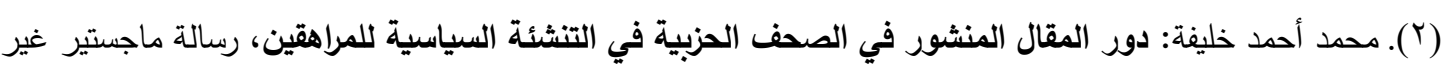

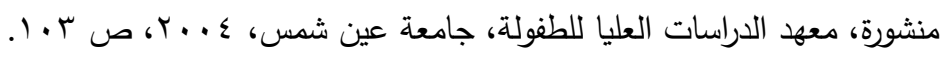


احترام المبادئ قبـل الأثخـاص: إذ لابد من توافر القناعـة بأن السلطة السياسية مودعـة في

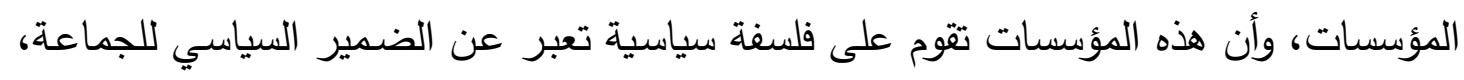

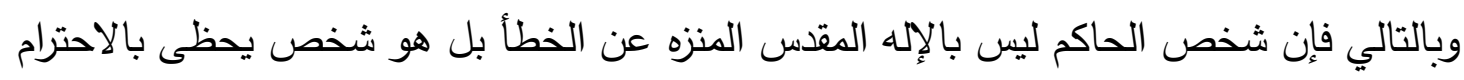

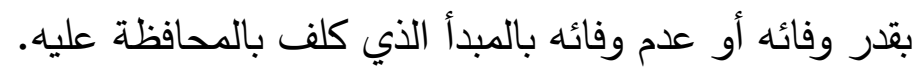
ويتضح مما سبق أن للوعي السياسي مستويين هما المستوى النظري: ويشمل المعرفة

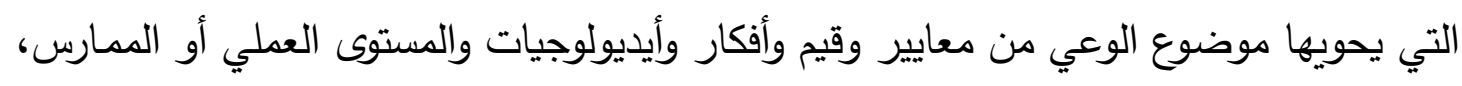

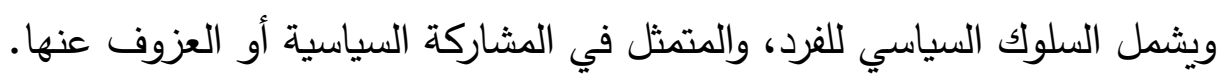

\section{r- مصادر تشكيل الوعي السياسي للطلاب}

توجد العديد من التنظيمات المجتمعية التي يمر بها الإنسان أثناء فترة التتشئة ينبغي

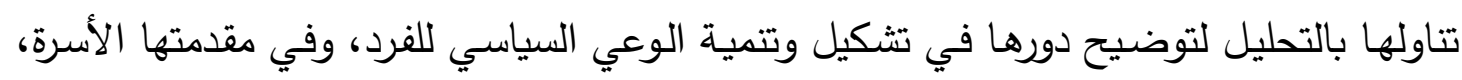
ووسائل الإعلام، والأحزاب، والمؤسسات التعليمية كالمدرسة والجامعة، ويمكن توضيح لوتيح دور كل

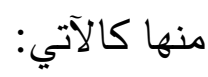

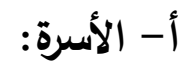

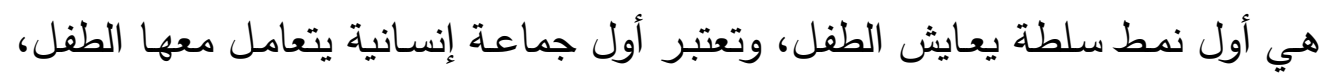

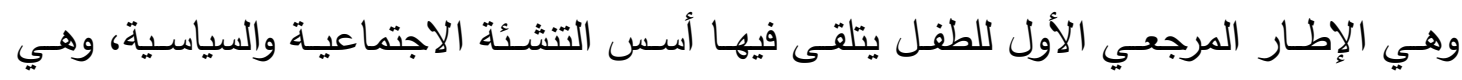

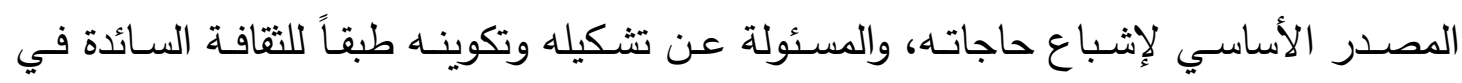
الأسرة، فالأسرة تعتبر أول نمط للسلطة عند الطفل. ويتعلم الطفل عن طريق الأسرة القيام بواجبه والمطالبة بحقوقه، ولاثك أن هذا لـأ يمثل نوعاً

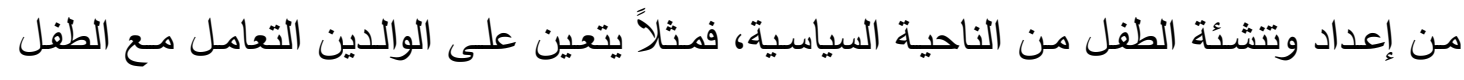

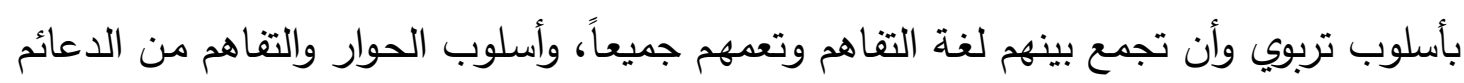

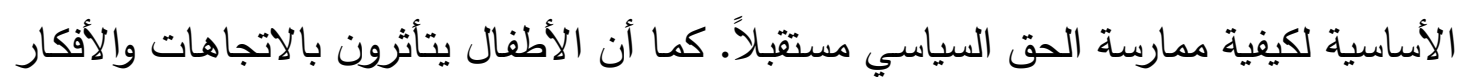

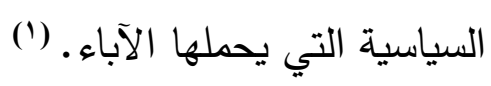
وتتحدد الثخصية السياسية للفرد بواسطة الأسرة من خلال التلقين الظاهرة، والكامن، أو

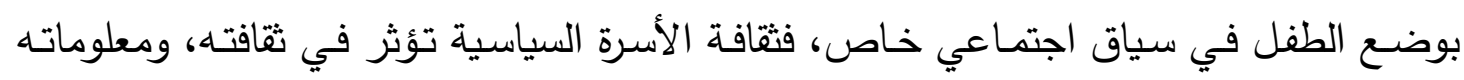
السياسية واتجاهاته نحو النشاطات السياسية. وتؤدي الأسرة دوراً حيوياً في التربية السياسية للأبناء من خلال إكسابهم ثقافة الحوار وإبداء الرأي والثقة بالنفس والاعتماد على الذات وتحمل المسئولية.

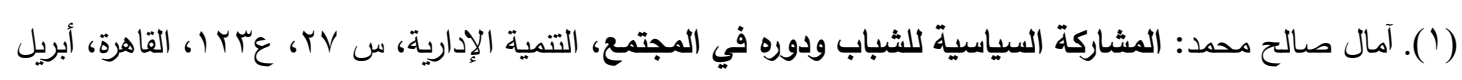
q... 
تؤودي وسائل الإعلام دوراً كبيراً ومهماً في التأثير على عقول المتلقين وعواطفهم. وتقوم وسائل الإعلام بوظيفتها السياسية بعدة طرق هي:

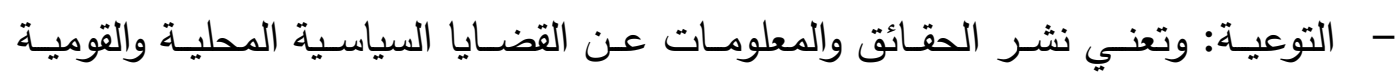

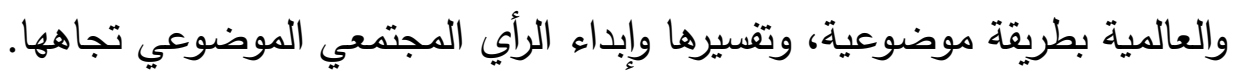

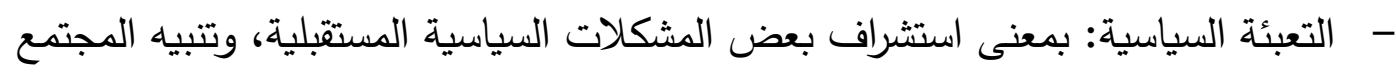
بها، وشحذ القدرات وتعبئة النفوس نحوها سواء سلباً أو إيجاباً.

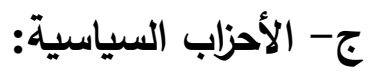

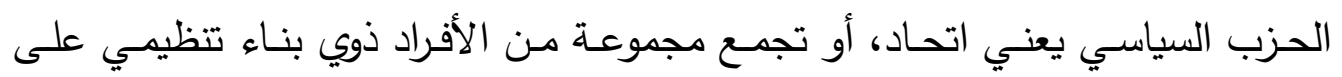

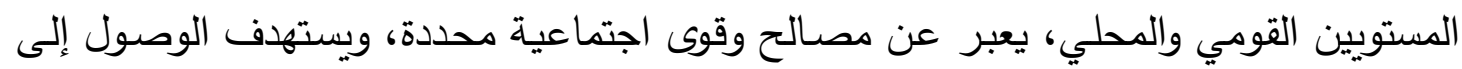
السلطة السياسية، أو التأثير بواسطة أنشطة متعددة، أو أن يتولى ممثلوه المناصب العاصئ العامة. (')

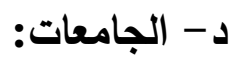

تعد الجامعة من أهم المؤسسات التربوية في المجتمع، واتسعت مسئولية الجامعة لتثمل

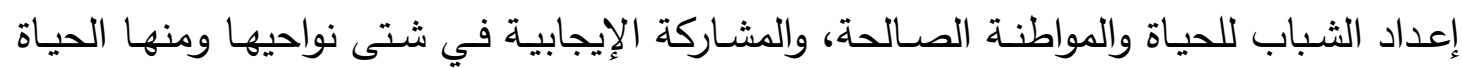

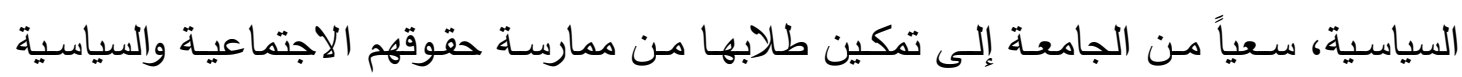
بكفاءة.

ولأن الجامعة هي العقل المفكر لأمتتـا العربية، والضمير الواعي المستتير لتوجهاتها

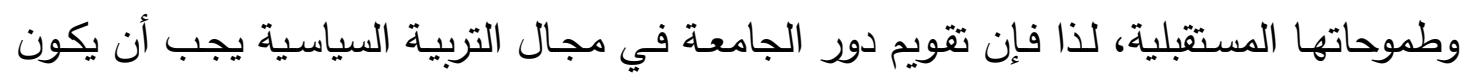

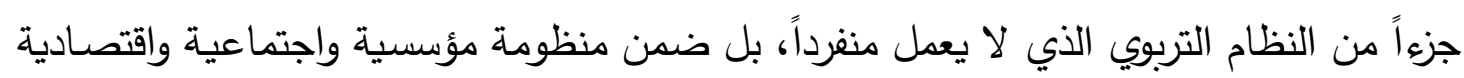

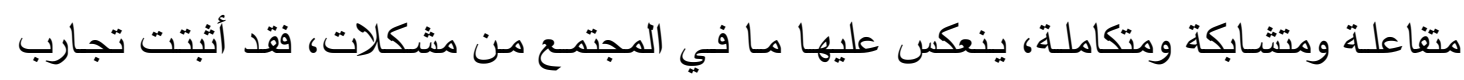

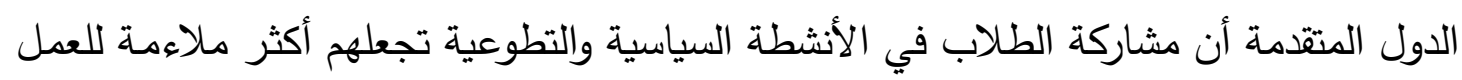

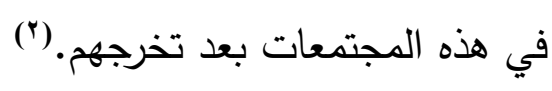
المحور الثاني: دور الجامعة في تنمية الوعي السياسي 1 - مسئوليات وادوار الجامعة لمور لجامعه

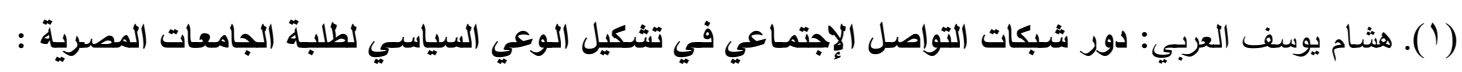

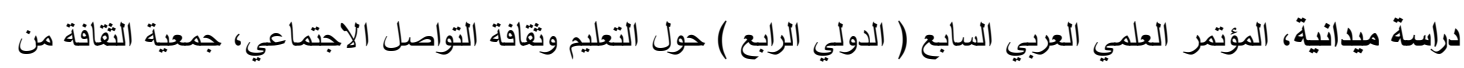

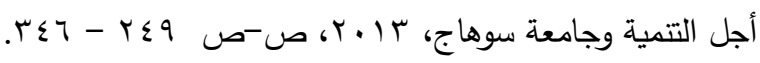

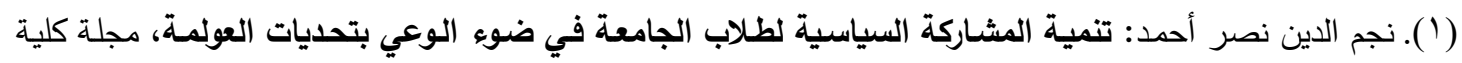

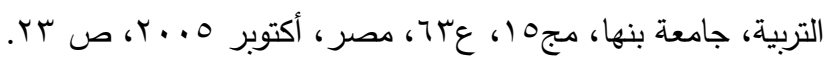


تتحدد مسئوليات ووظائف الجامعة فيما يلي ('):

أولاً: دور علمي ثقافي لاستيعاب ونشر المعارف والبحوث ومتابعة تطورها.

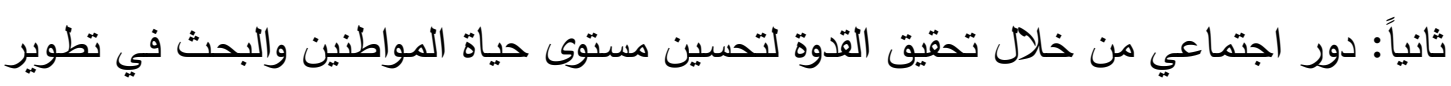

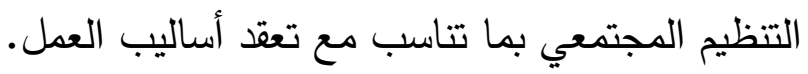
ثالثاً: دور سياسي للعمل على ملاحقة التطورات الحادثة في المجتمعات المتقدمة ومتابعة تأثير

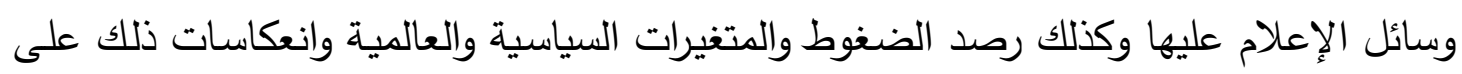

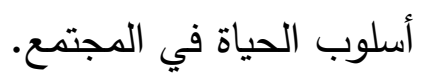

ومما سبق يتضح أن المؤسسات التعليمية بصفة عامة والجامعة بصفة خاصـة من أهم

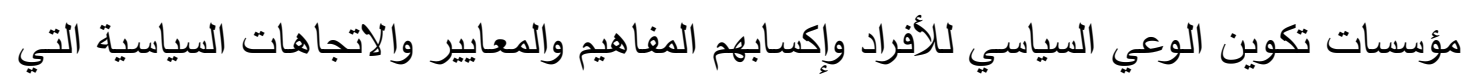

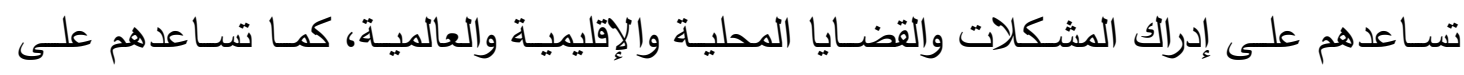

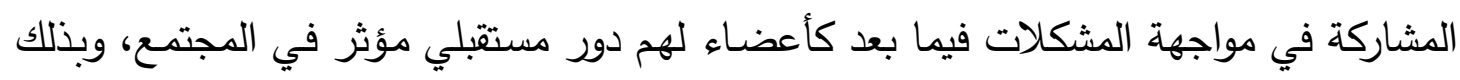
تتأكد العلاقة الوثيقة بين التعليم والسياسة لخدمة المجتمع.

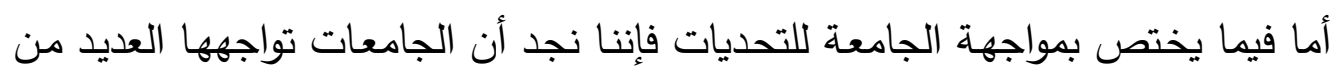

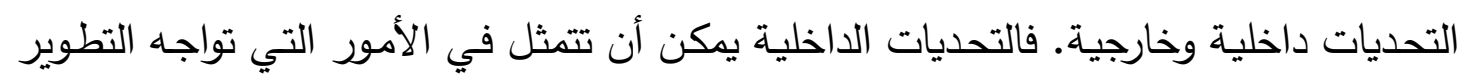

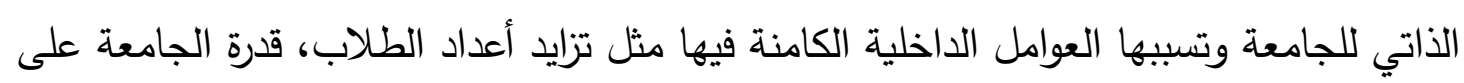

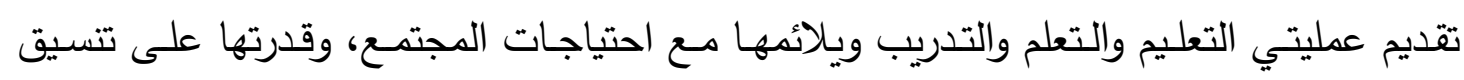

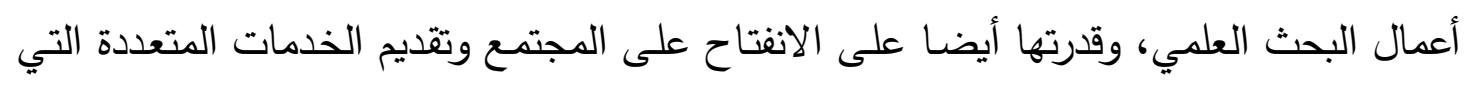

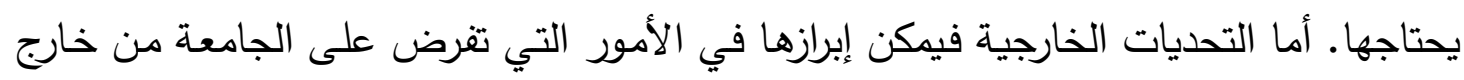

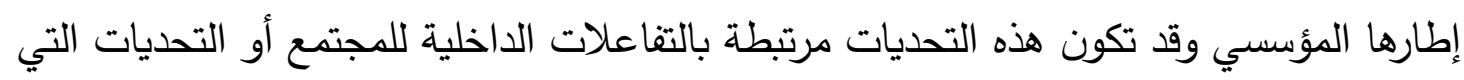

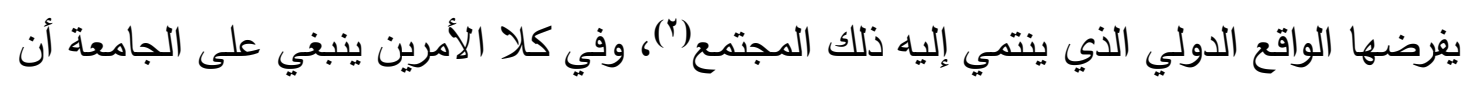

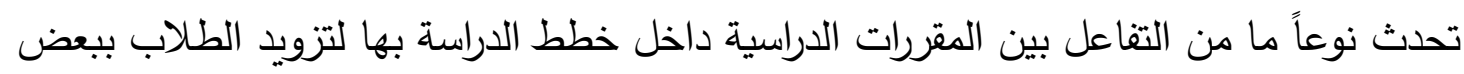

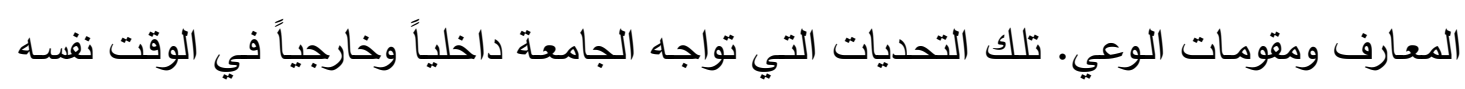
تساعد تلك المقررات على إكساب الطلاب الوعي بمختلف جوانبه بالنسبة للمجتمع ككل أسوة بما

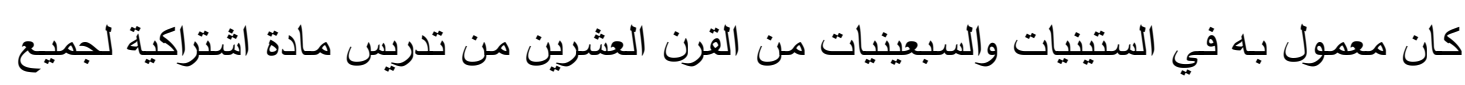

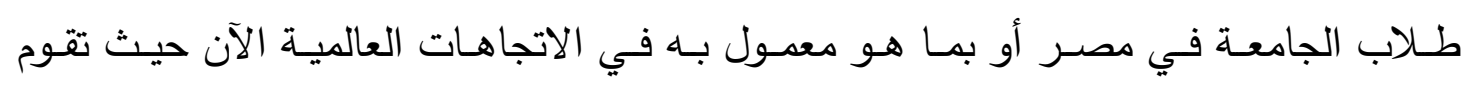
الجامعات بتدريس بعض المواد التي تساعد على تتمية الوعي السياسي لدى الطلاب مثل "العلوم

(ץ). إبراهيم بدران: تطلعات لمصر المستقبل في السياسة والتنمية البشرية والبحث العلمي، القاهرة، مكتبة نهضة مصر، (19 (1999 (ץ). فاطمة محمد محمود حسن: تفعيل الوعي السياسي لدى شباب الجامعة ودوره في تنمية المواطنة، مجلة التربية،

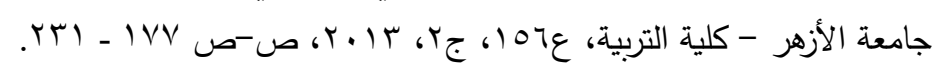


السياسية والاجتماعية، الاقتصاد السياسي، التاريخ السياسي، القانون السياسي، وهذه المواد تدرس

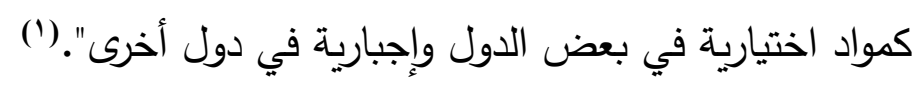

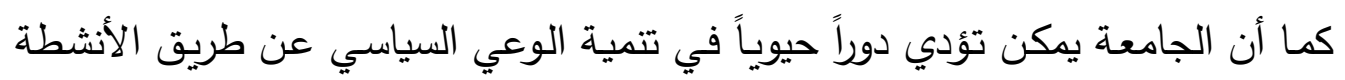

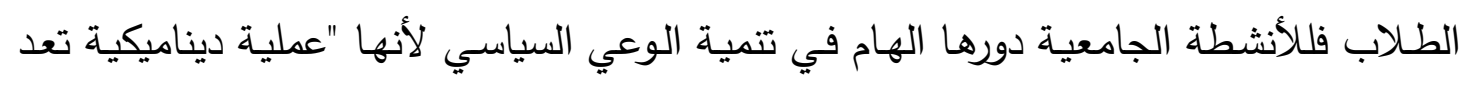

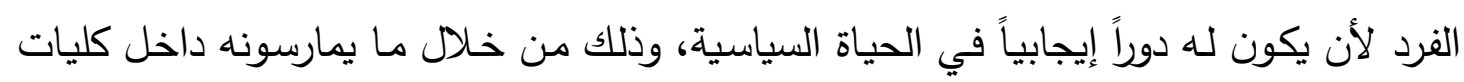

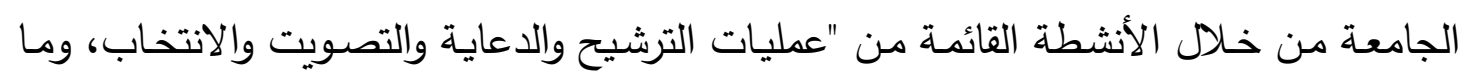

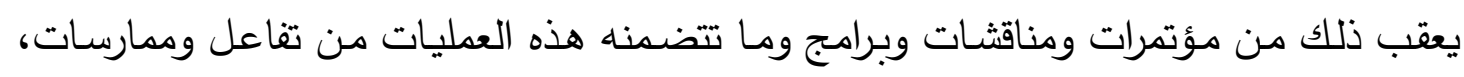

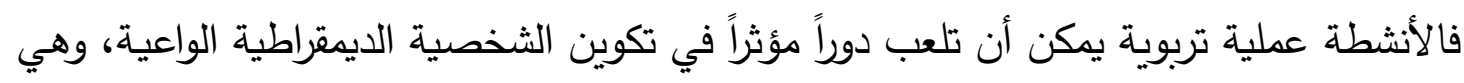

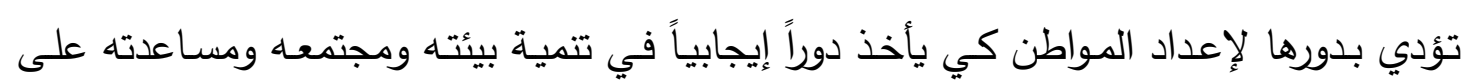

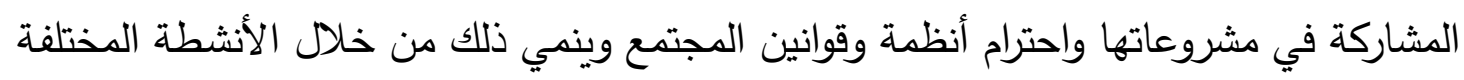

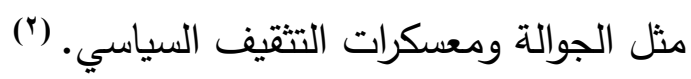
فالأنثطة الطلابية تسهم بثكل فعال في تكوين الثخصية السوية للطلاب وتجعلهم

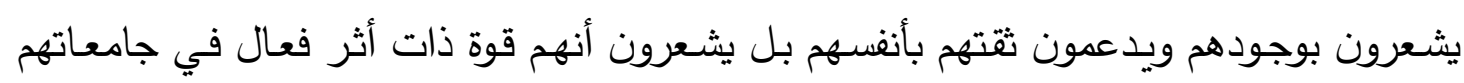

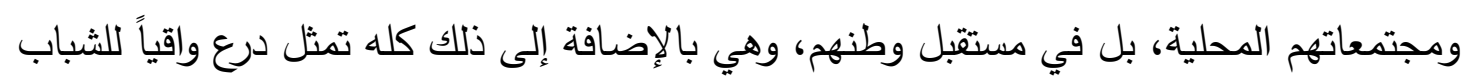
ضد العنف والتطرف. كما أن المقررات الدراسة داخل الجامعة تسهم بنصيب وافر في تتمية الوعي السياسي والمواطنة، حيث يكاد يتفق خبراء التربية والمختصين في المناهج الدراسية على أن المقررات

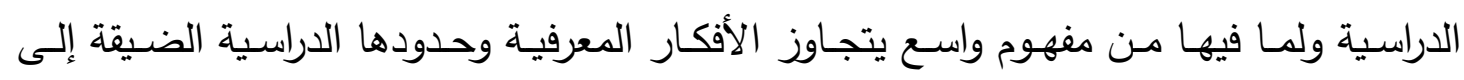

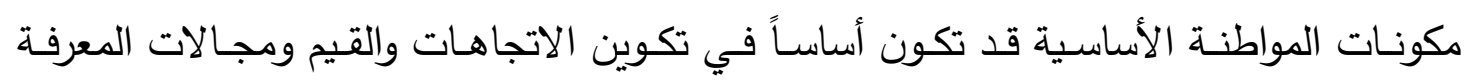
والمهارات المجتمعية والوجدانية.

ولابد أن تتضمن المقررات الدراسية بالجامعة مقرراً للثقافة السياسية يتم تدريسه في جميع

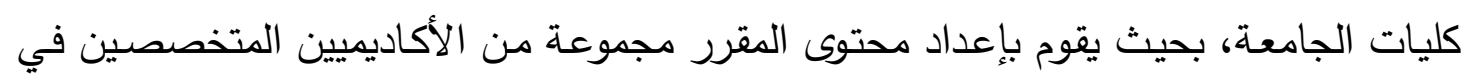

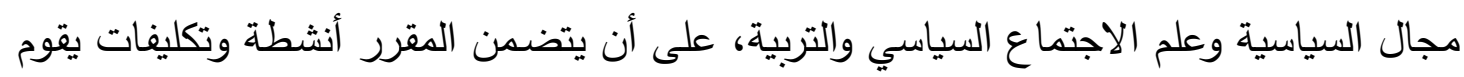

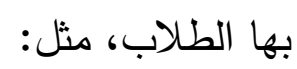
- كتابة تقارير تحليلية إخبارية عن الموقف السياسي الدولي والإقليمي والداخلي. - كتابة تقارير عن الجلسات الدذاعة للمجالس التشريعية. - ت تظيم مناظرات محدودة داخل قاعات التدريس حول موضوعات سياسية يتفق عليها. (1). Hiroshima University bulletin, Collage, 1994-1995, p. vol. 61.- Kennesaw State Collage, undergraduate cataloge 1994-1995 Coorgla, 1995- p.p. 1991-1993. 
- - - عرض ونقد وتحليل لكتاب، أو مقال سياسي، وإقامة حوار بين الطلاب حوله.

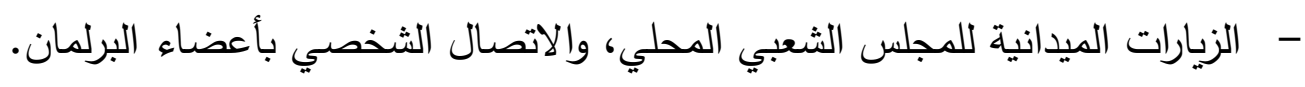
- - إجراء الاستطلاعات المبسطة؛ للتعرف على اتجاهات الرأي العام تجاه القضايا المختلفة.

ويمكن التعرف على دور الجامعة في تتمية الوعي السياسي لطلابها، من خلال التعرف على دور كل هن عضو هيئة التدريس، والمقررات الدراسية، والأنشطة الجامعيـة والاتحـادات

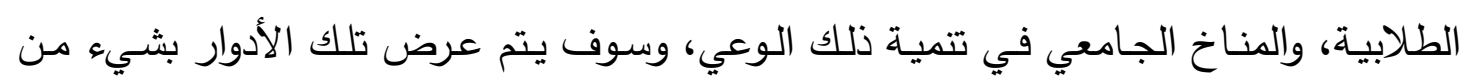
الإيجاز فيما يلي:

أ- دور عضو هيئة التدريس في تنمية الوعي السياسي للطلاب: يعتمــ التـدريس الجـامعي الفعـال بالدرجـة الأولسى على شخصـية المحاضــر وذكائسه

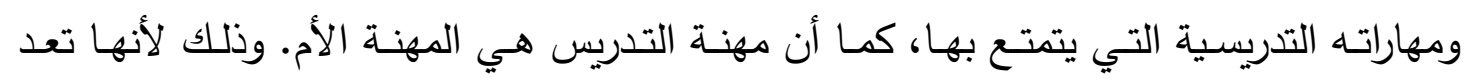
المصدر الأساسي الذي يمد المجتمع بالعناصر البشرية المؤهلـة علميا، واجتماعيا، وسياسيا، وفنيا، وأخلاقيا، الأمر الذي يبرر أن لعضو هيئة التدريس دور حيوي في تتمية الوعي السياسي باليني

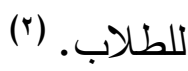
وقد تعددت وجهات النظر حول الدور السياسي لعضو هيئة التدريس، حيث يوجد فريق ينادي بضرورة أن يكون لعضو هيئة التدريس موقف سياسي داخل الجامعة، وفريق آخر يؤيد أن يكون لعضو هيئة التدريس موقف سياسي خارج الجامعة، ولما كان عضو هيئة التدريس هو أحد الدحاور الرئيسة في الجامعة فإنه تقع عليه مسئولية تتمية الوعي السياسي للطلاب باعتباره

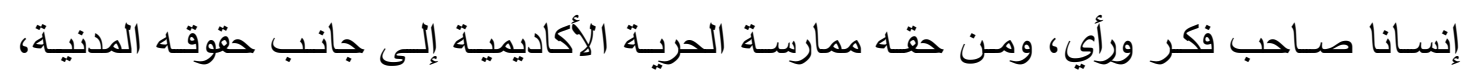
والتعبير عن رأيه دون أدني خوف، على ألا تؤدي آراؤه إلى نوع من التحريض. وكلما كان عضو هيئة التدريس مؤمنا بقيم النظام السياسي، كان أكثر قدرة على غرسها

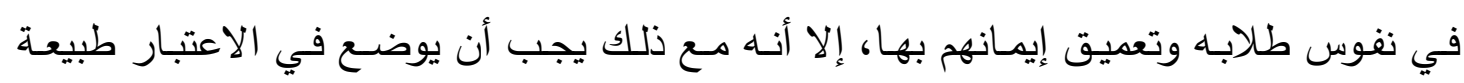
العلاقة بين عضو هيئة التدريس وبين طلابه، فإذا كانت تلك العلاقة ذات طبيعة ديمقراطية، فإنه

( (1). المحروقي، ماجد بن ناصر بن خلفان: دور المناهج الدراسية في تحقيق أهداف تربية المواطنة، ورقة عمل مقدمة

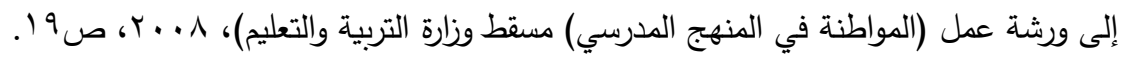

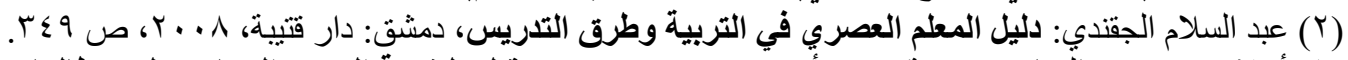

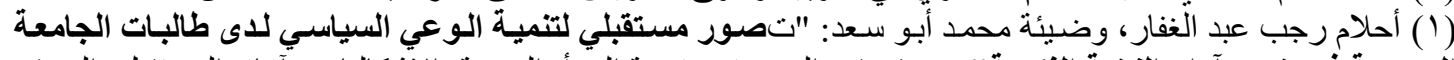

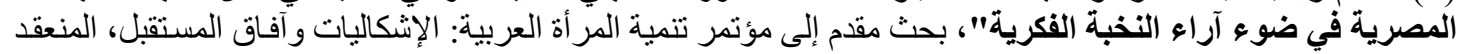

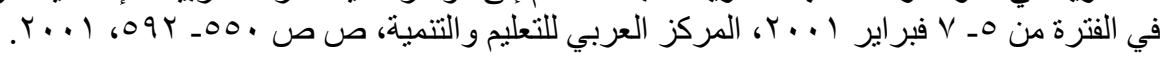


ثــة نوع من التواصل يحدث بين عضو هيئة التدريس وبين طلابه في منـاخ تسوده الحريـة والتعبير عن الرأي، الأمر الذي يؤدي إلى إكسابهم القيم السياسية المرغوبـة، ومن ثم تفعيل مشاركتهم في الحياة السياسية، أما إذا كانت العلاقة بين عضو هيئة التدريس وبين طلابه ذات إتهرئ

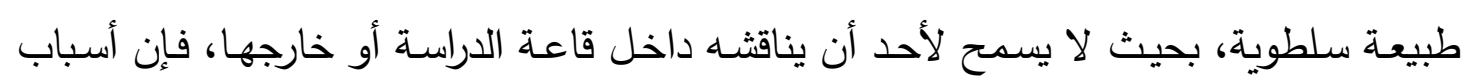

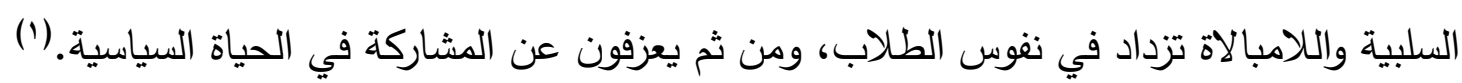
وقد أشـار "سليم شعبان" إلى أن عضو هيئة التدريس كي يقوم بدوره في نشر وتتمية الوعي السياسي لطلابه، فيجب عليه أن: - يتيح الفرصة لطلابه للتعبير عن آرائهم السياسية. - يتيح فرصة أكبر للحوار والمناقثة الحرة مع طلابه. - يكون قدرة سياسية لطلابه.

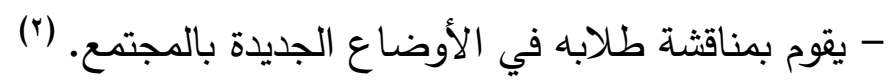
ب- دور المقررات الدراسية في تنمية الوعي السياسي للطلاب:

تؤثر الجامعـة في تربيـة طلابها سياسيا من خـلال بعض المقررات الدراسية المعنيـة بالوعي السياسي مثل بعض المقررات ذات الطابع السياسي أو القومي والتي يدرسها جميع الطلاب بصرف النظر عن الحدود التخصصية لهم، حيث توفر تلك المقررات الأساس التثقيفي في التربية السياسية. (ץ) وللمقررات الدراسية دور رئيس في عملية تتمية الوعي السياسي لطلاب الجامعة، فهي المحتوي الذي يتم إدخاله في ثقافة الطالب الجامعي، وتثبيته بالممارسات السياسية المختلفة داخل الجامعة كجزء مكمل للحياة الجامعة، كما أظهرت الدراسات التحليلية للمقررات الدراسية، أن الدقررات الثقافية ذات أثر كبير على الوعي السياسي للطلاب. ولكي تتكون الثقافة السياسية

(r) عبد الحليم الزيات السيد: التتمية السياسية_. دراسة في علم الاجتماع السياسي-الأدوات والآليات. الإسكندرية: دار

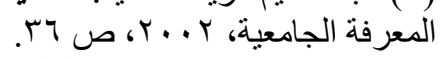

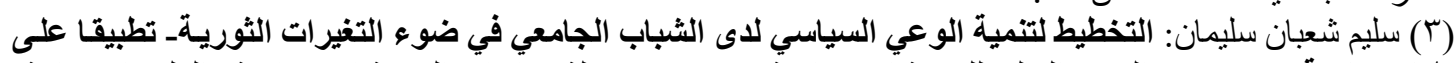

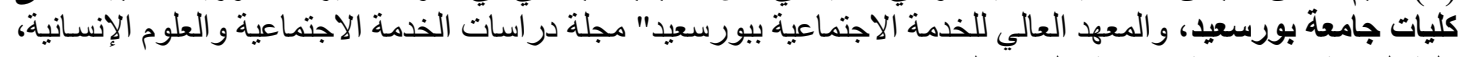

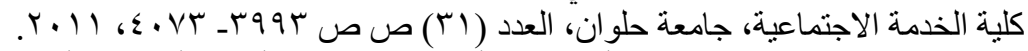
(1) السيد سلامة الخميسي: الجامعة والسياسة في مصر - دراسة نظرية وميدانية عن التربية السياسية لثباب الجامعة.

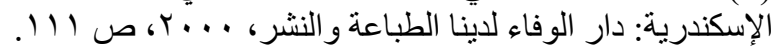


لدى الطـلاب فإنـه ينبغي إعطائهم المقررات المؤثرة في تكوين وتتمية قيم الولاء والانتماء (')، وتتضمن تلك المقررات العديد من المفاهيم التي تغرس وتتمي الشعور القومي والوطني، وتشكل فكر وعقول الطـلاب ببعض المفـاهيم السياسية التربويـة بمـا يعود عليهم وعلى المجتمـع بالنفع

والفائدة. (r)

ويؤكد "أندرسون" Anderson على أن المقرر الذي يتجنب التدخل السياسي لا يعد

مقررا فعـالا، وأنـه لابـد أن يعـرض المقرر للقيم السياسـية الرئيسـة بشـيء مـن التفصـيل مثل:

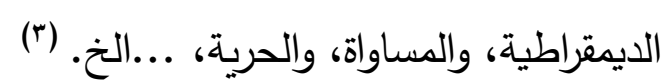

وتجدر الإشـارة إلى أن المقررات الدراسية حتى تؤدي دورها في تتميـة الوعي السياسي

للطسلاب، فيجب عليها أن تؤكد على مفـاهيم ومنطلقـات سياسـية تحث على المحافظة على الدستور، واحترام حقوق الوطن، والتعريف بحقوق المواطنين وتتمية المشاركة السياسية لديهه، هذا وبالإضافة إلى تأكيدها على مفاهيم من قبيل: التعليم من أجل السلام، والتعايش مع الآخر، واحترام الأقليات، والهوية الوطنية. (؛)

ت - دور الأنشطة الجامعية والاتحادات الطلابية في تنمية الوعي السياسي: للطلاب: يمكن للجامعة أن تقوم بدور أساسي في تتمية وعي الطلاب بمختلف جوانبه وبخاصسة الوعي السياسي، وذلك من خلال إتاحة العديد من الأنشطة التي يمارسها الطلاب في مجالات متعددة منهـا (الثقافيـة، والاجتماعيـة، والـرحلات، والندوات... الـخ). والمنبثقـة عن الاتحـادات الطلابية التي زاد الاهتمام بها بعد التحول في النظرة لوظيفة الجامعة وأصبحت تلك الأنشطة ركيزة هامة في تنمية جوانب شخصية الطالب وصقلها. (•)

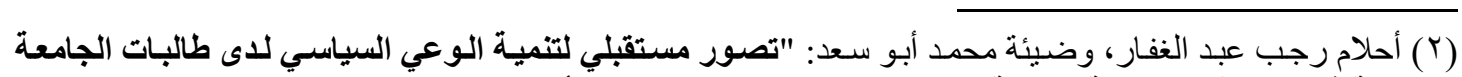

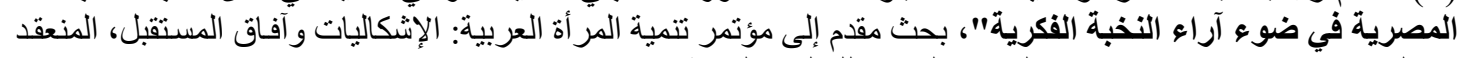

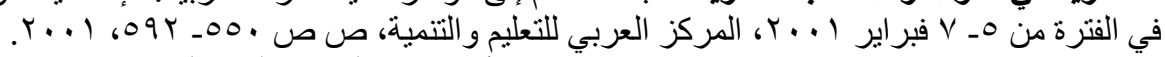

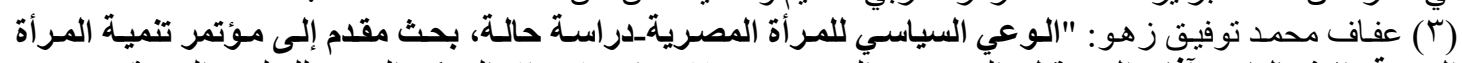

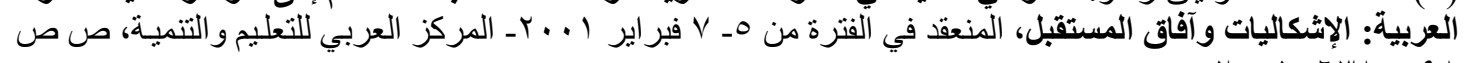

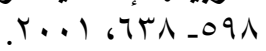

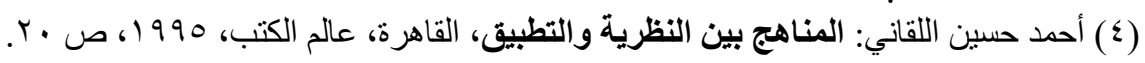
(5). Burno Losito (2003). Civic Education in Italy intended Curriculum and Students' Opportunity to learn, a vailableat: www.sooi.onlineiournal.DE, 2003-21 index .html

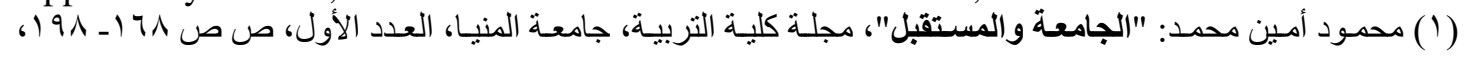


هذا وقد أصبح النشاط جزءا مهما في الحياة الجامعية، خاصسة أن التربية المعاصرة لا تفرق بين الدراسـة داخل قاعات المحاضـرات وخارجها فكلاهما مكمل للآخر والهدف واحد وهو نمو الطالب، لذلك يتعين على طالب الجامعة ليس مجرد التعرف إلى أوجـه النشاط الطلابسي فقط، وإنما الإسهام فيه أيضا، الأمر الذي يتطلب من الجامعة إعطاء اهتمام أكبر بتلك الأنشطة.

وللأنشطة الجامعيـة التي تقوم بها الاتحـادات الطلابيـة دورهـا الهام في تتميـة الوعي السياسي، وذلك من خلال ما تمارسه تلك الاتحادات داخل كليات الجامعة من عمليات الترشيح والدعاية والتصويت والانتخاب، وما يعقب ذلك من مؤتمرات ومناقثات وبرامج وما تتضمنه من تفاعل وممارسـات، فالأنشطة عمليـة تربويـة يمكن أن تلعب دورا مؤثرا في تكوين الشخصـية الديمقراطية الواعية.

كما تساعد الأنشطة الجامعية الطلاب على الممارسة السليمة للنشاط السياسي من خلال المبادئ السياسية السائدة، وتختلف هذه الأنشطة في طبيعتها وأنواعها ودرجة الحريـة المسموحة للطلاب في ممارستها من مجتمـع الآخر، فالمجتمعات الديمقراطية غالبا مـا تتجهـ نحو توسيع نطاق المشاركة الطلابية وتكثيف أوجه النشاط الطلابي لدرجة تسمح بوجود جماعات سياسية ذات آراء متفاوتة . (r) مدا سبق يتضـح أن الاتحـادات الطلابية (مجالس الطلاب) هي عبارة عن التظيمات الثرعية الممثلة لطلاب الكليات والمعاهد والجامعات التي يمارسون من خلالها كافة الأنشطة، الاجتماعيـة والثقافيـة، والرياضـية، والفنيـة، والسياسية، وهي التي ترعي مصـالحهم وتقوم على تتظيم وكفالة ممارسة النشاط الطلابي، وهي أيضا ممثلهم الوحيد أمام الجهات المعنية. (؛) كمـا تعرفهـا "سـهام محمـود" بأنها القنـوات الثـرعية التي يمـارس مـن خلالهـا الطـلاب أنشطتهم المختلفـة، كمـا تمثل أحد الميادين الرئيسـة لتربية الطـلاب ديمقراطيا وتهيئتهم دخول

الأق) بسام محمد أبو حشيش: دور كليات التربية في تنمية قيم المواطنة لاى الطلبة المعلمين بمحافظات غزة، مجلة جامعة

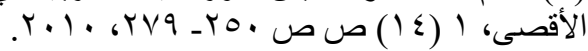

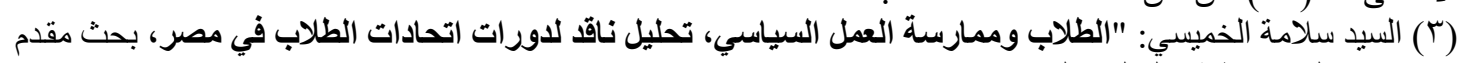

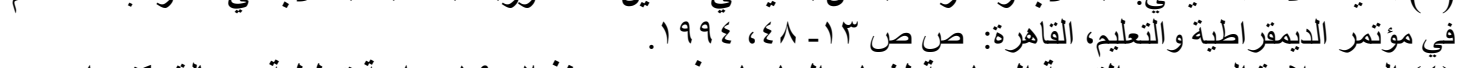

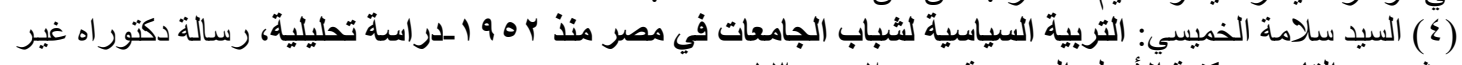

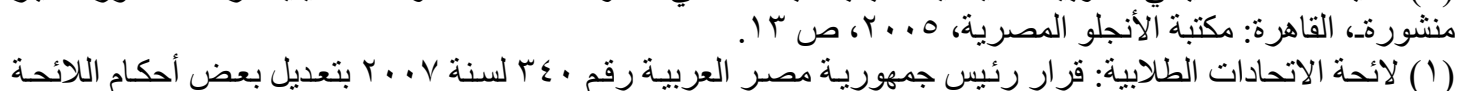

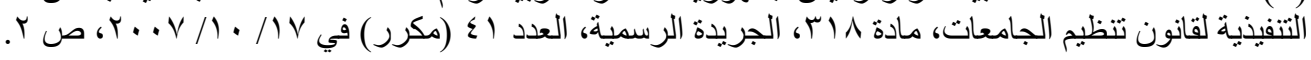


عمليـة الوعي السياسي والمشـاركة في اتخـاذ القرار داخل مؤسساتهم التعليميـة وخارجها، كمـا تسـاعد الإجـراءات المصـاحبة لتكوين الاتحـادات الطلابيـة مـن ترشيح، ودعايـة، وتصـويت، وانتخاب، وما يعقب ذلك من مسئوليات، على تأكيد دعائم الديمقراطية داخل الجامعة، وبناء

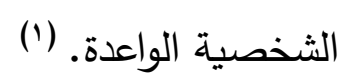

ث- دور المناخ الجامعي في تنمية الوعي السياسي للطلاب: يمكن أن تلعب الجامعات دورا بارزا في التربية السياسية لطلابها إذا مـا توفرت سبل سيل الاستثمار الواعي لإمكانات الحياة الجامعية، واتصال بين الجامعة والعالم المحيط بها، إلا أن

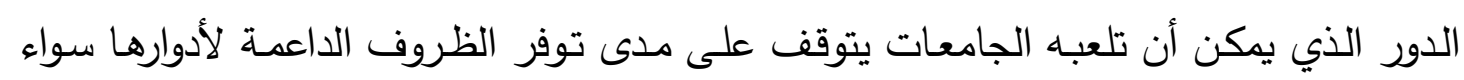

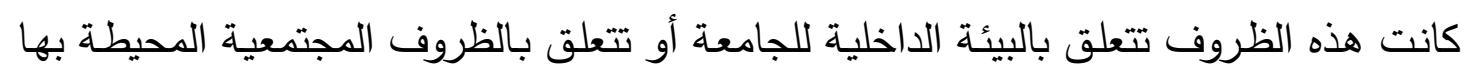

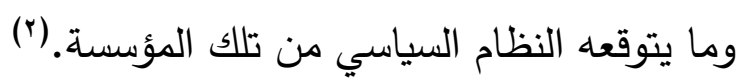
ويوجد اتجاهان في فهم العلاقة بين الجامعة والسياسة أحدهما يقبل التصور الذي يرى لنوفي أن الجامعة هو موطن الدراسـ The House of Study ويمثل هذا الاتجاه المحافظون والمعتدلون من رجال الفكر والسياسة، أمـا الاتجاه الثاني فيقبل التصور الذي يرى أن الجامعة هي موطن السياسة The House of Politics ويمثل هذا الاتجاه أصحاب الفكر اليساري المتطرف واليمين المتطرف، وقد أوضـت الدراسـات المعاصـرة أن هناك ثلاثة أدوار سياسية للجامعـة تتمثل في: التكامل السياسـي، والتتشئة السياسية، والتجنيد السياسي وإعداد الصفوة السياسية. (") وتجدر الإثـارة إلى أن المناخ الجامعي إذا كان صـحيا سليما مشبعا بالفهم والتقدير المتبادل وقيم العدالة والحرية والمساواة، قائما على المشاركة الجماعية والتعاون والاحترام، مشجعا لإنى على التفكير الناقد.... التخ، فإنها بـلا شك سيساعد على تنشئة الفرد سياسيا، فضـلا عن نمو

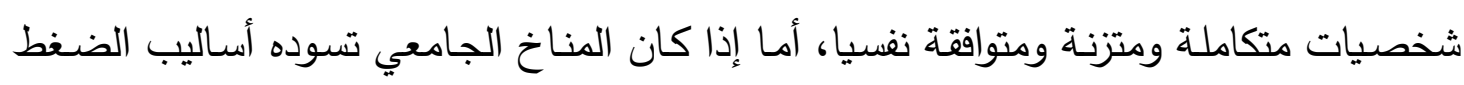
والقسر والإكراه ومشاعر الخوف والتهديد، وتصدع العلاقات الاجتماعية، والفوضسى والتسيب

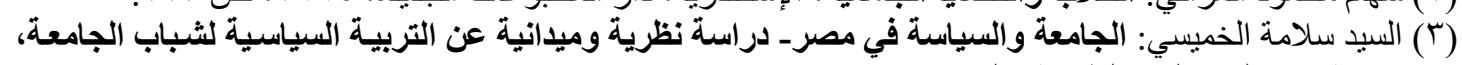

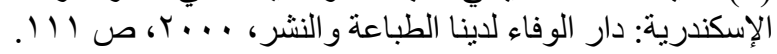

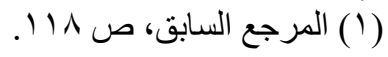


والحريـة الزائدة غير المسئولة، فإنـه يؤدي في أغلب الأحـوال إلى نـو مظـاهر السلوك الثـاذ

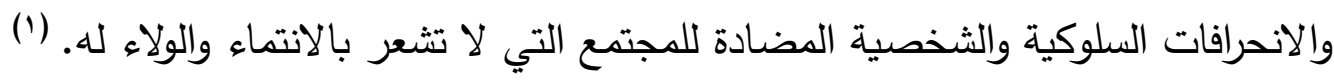

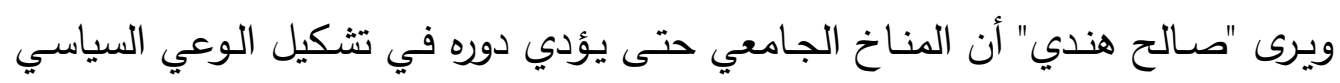
للطلاب، فيجب عليه أن يعمل على أن: - يتقبل الطلاب بعضهم البعض بغض النظر عن أصولهم وخلفياتهم الثقافية. - يتعامل الطلاب مع بعضهم بروح الأخوة والتسامح عند مواطن الاختلاف السياسي. - يتعاون الطلاب مع بعضهم ويعملون بروح الفريق. - يتعامل المعلمون مع الطلاب بعدل واحترام. - يولي المعلمون اهتماما بالسلوكيات السياسية للطلاب. - يحترم الطلاب القواعد واللوائح الجامعية فيما يخص الأمور السياسية وغيرها. - يثعر الطلاب بالأمان داخل الجامعة. - يسود التعاون بين أعضاء هيئة التدريس وبعضهم البعض. - يسود التعاون بين أعضاء هيئة التدريس والنظام الإداري سواء داخل الكلية أو على مستوى

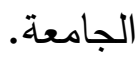
- تقوم الجامعة بتتمية قدرات أعضاء هيئة التدريس في المجالات المختلفة العلمية، والاجتماعية، والسياسية.... الخ. - يقوم أعضاء هيئة التدريس بأداء أدوارهم المختلفة بحب وإخلاص دون شكوى أو تذمر .

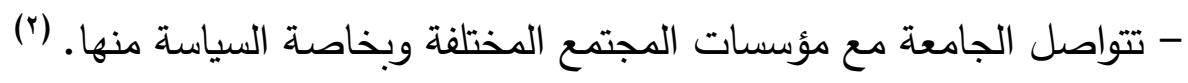
وفي ذات السياق يرى "سليم شعبان سليمان" أن المناخ الجامعي من أجل أن يقوم بدوره في تتمية الوعي السياسي للطلاب، يجب عليه أن: - يزيد من قدرة الطلاب على النقد والحوار البناء. - يتيح الفرصة للطلاب للمشاركة في اتخاذ القرارات المتصلة بجوانب الدراسة.

(r) عبد المطلب أمين القريطي: دور الددرسة في عملية التنشئة السياسية للطفل، مجلة ثقافة الطفل، المجلد (IV) (IV)،

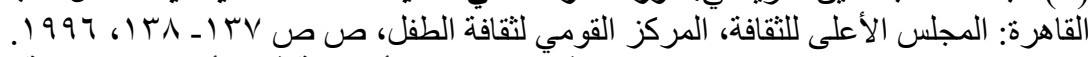

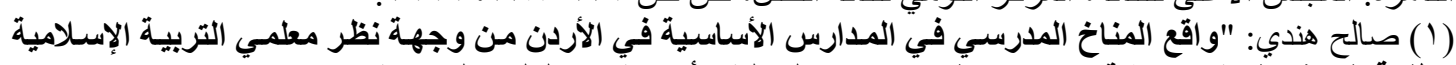

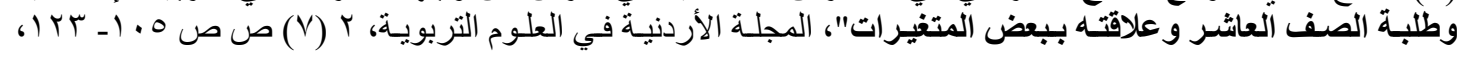


- يتيح الفرصــة للطـلاب لمناقشــة بعضـهم البعض ومناقثــة معلميهم في الأكسور السياسـية بالمجتمع. - يوظف المناهج والأنشطة الجامعية في التعرف على المشكلات الحقيقية الموجودة بالمجتمع ومحاولة حلها. - يوفر فرص الحوار مع القيادات السياسية الجديدة بالمجتمع. - يسهم في تخريج طلاب أكثر التزاما وتحملا للمسئولية.

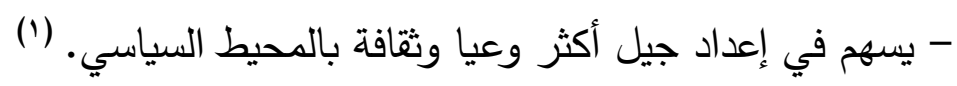
منهج البحث: استخدم البحث المنهج الوصفي، الذي يهتم برصد الواقع ووصف الظاهرة كما تحدث في الواقع الفعلي له، (rاوذلك بقصد التعرف على الظاهرة وتحديد الوضع الحالي لها والتعرف على جوانب القوة والضعف فيها من أجل معرفة مدى صلاحية هذا الوضع أو مدى الحاجة لإحداث تغييرات جزئية أو أساسية فيه.(ץ)

تحدد البحث الحسالي بالمحددات البحثيـة الأتيـة: رؤيـة طـلاب الجامعة الكويتين

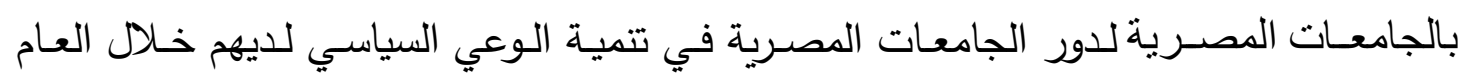

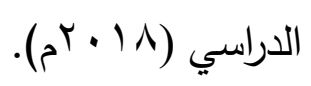
الحـدود البثـرية: اقتصـر البحـث الحسالي على بعض طـلاب الجامعـة الكـويتين بالجامعـات المصرية. الحـد المكانيـة: طبق البحث على بعض طلاب الجامعة الكويتين بالجامعات المصرية إناث وذكور.

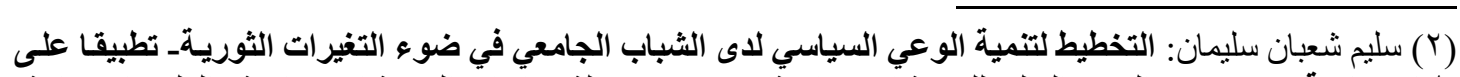

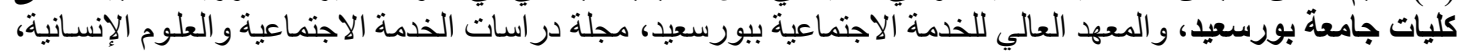

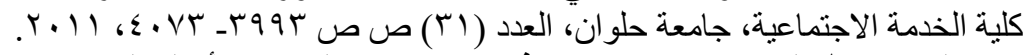

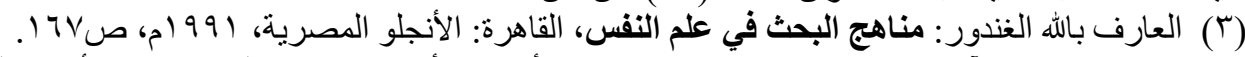

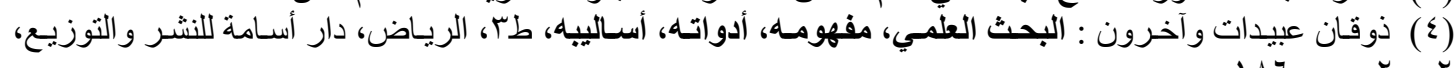


العدود الزمانية: طبق البحث خلال العام الدراسي الحالي (1 • 9/9 1 • rم).

نتائج البحث:

في ضوء الاطار النظري ونتائج الدراسات السابقة يتضح الاتي: فيما يخص دور الأنثطة الطلابية في تنمية الوعي السياسي لاى طلاب الجامعة الكويتين

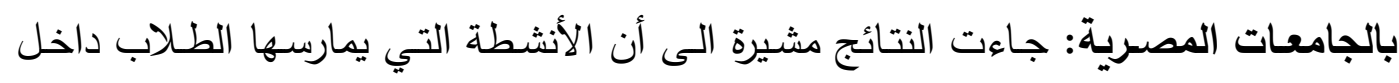

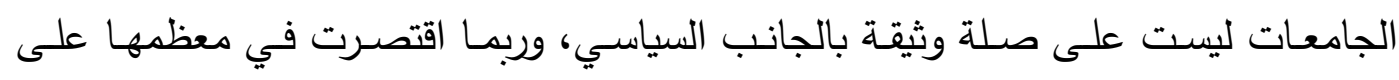

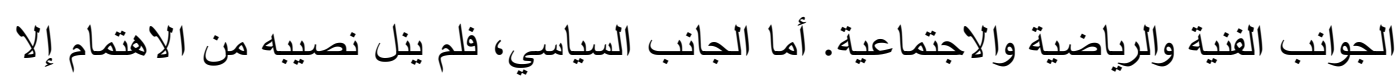

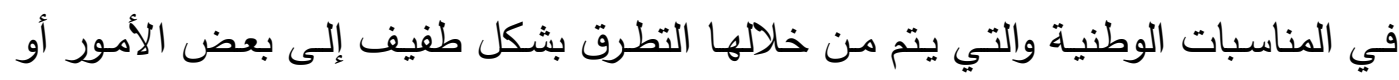

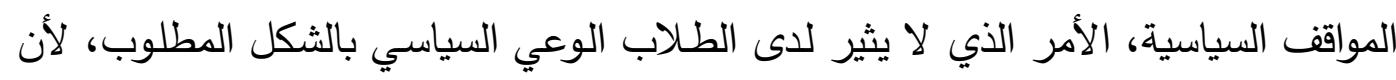

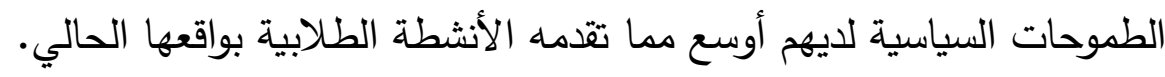

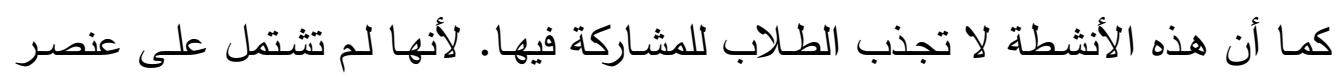

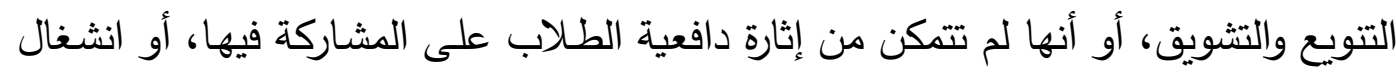

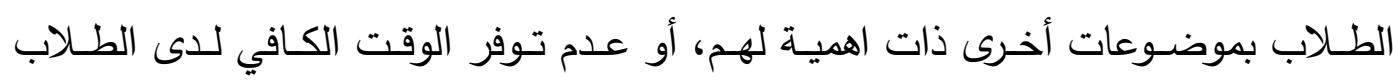

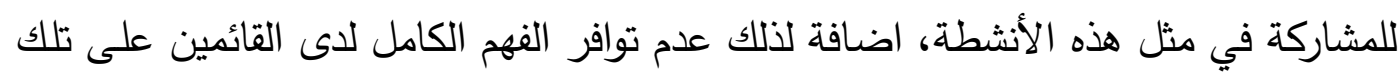
الانشطة بالجامعات باهمية الجانب السياسي لاى الطلاب.

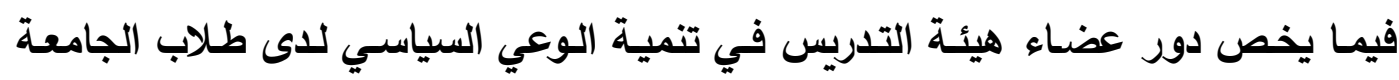

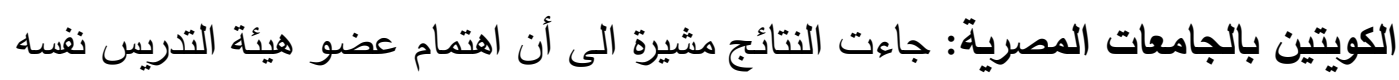

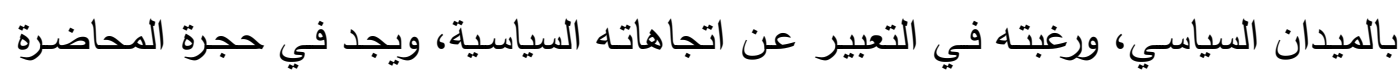

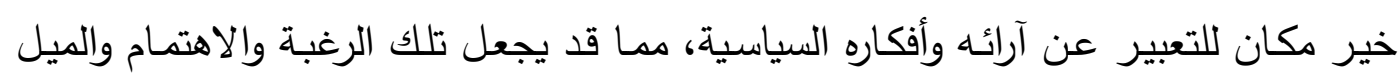

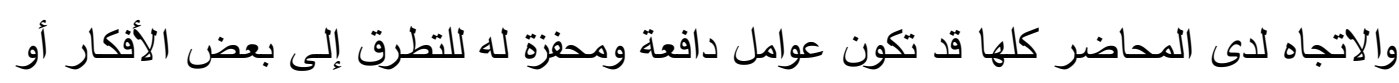

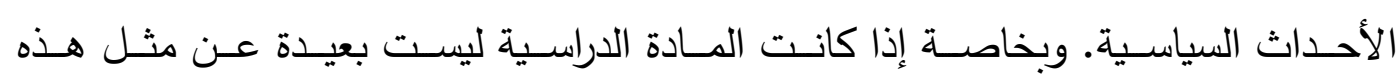
الموضوعات.

وعلى الرغم من أهمية هذا الدور إلا أن عضو هيئة التدريس لا يؤديه بالثكل المطلوب.

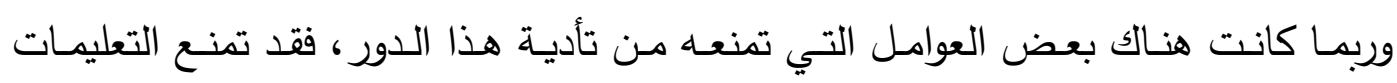

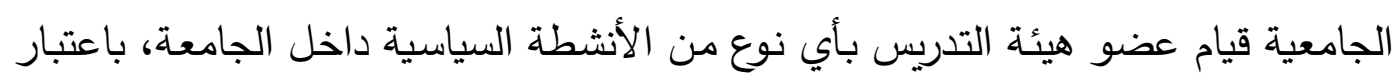

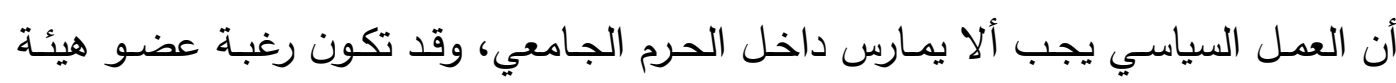

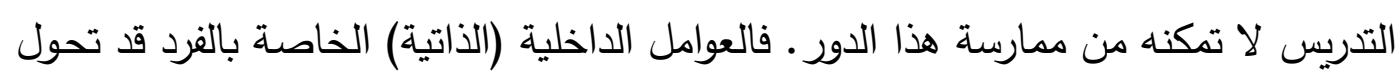

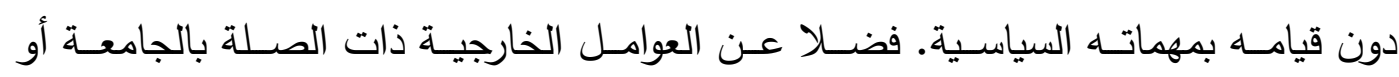


مؤسسات الدولة خارج الجامعة التي قد لا تتيح الفرصة لعضو هيئة التدريس لممارسة مثل هذا النشاط داخل الجامعة. امـا أن المنــاخ الجـامعي ودوره فـي تنميـة الـوعي السياسـي لطـلاب الجامعـة الكـويتين

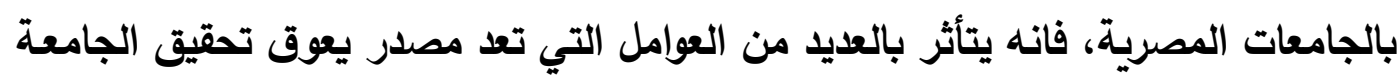
لهذا الدور ومنها

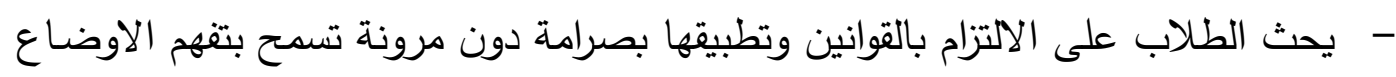

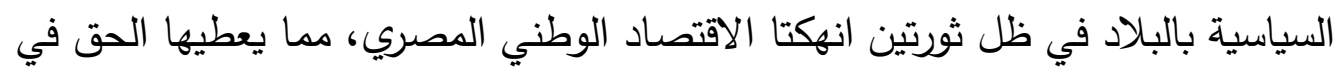

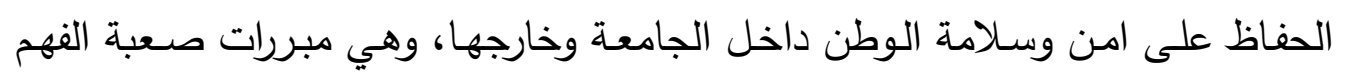
لاى الثباب الجامعي المتحمس للمشاركة السياسية بشكل فعال. توصيات البحث: - n

في ضوء ما تم التوصل إليه من أدوار لعضو هيئة التدريس، والمقررات الدراسية، والأنثطة

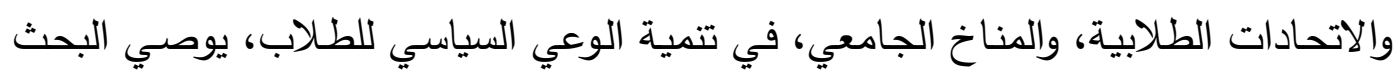
بالآتي:

- تبظيم حملات تثقيفية سياسية، لتتمية الوعي السياسي للدى طلاب الجامعات خاصـة الوافدين منهم بوصفهم أعضاء فاعلين في مجتمعهم.

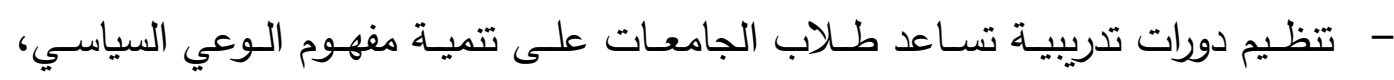
وممارسته عمليًا في اطار الانشطة الطلابية داخل تلك الجامعات.

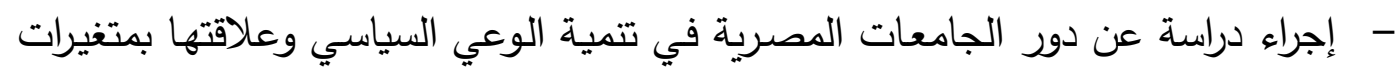
أخرى مثل الثقافة السياسية، والتربية السياسية.

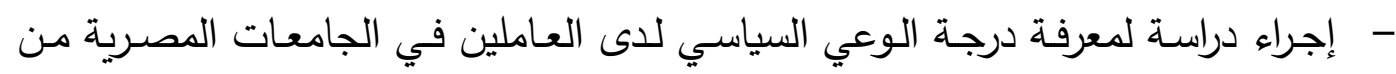
أعضاء هيئة التدريس، والمسئولين عن شؤون الطلاب. - تبني عضو هيئة التدريس لفلسفة الحوار وتقبل الاختلاف في الآراء بين الطلاب.

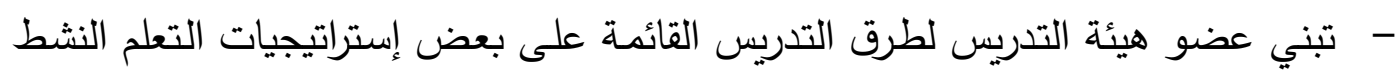

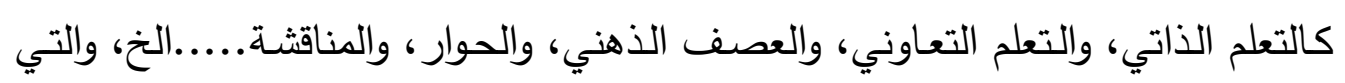

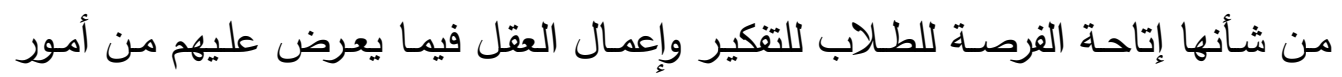
تعليمية بصفة عامة، وأمور سياسية بصفة خاصة. - تضمين المقررات الجامعية مقرر أو أكثر عن التربية السياسية.

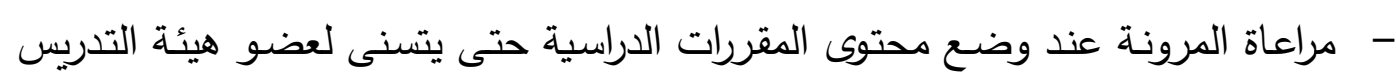
تناوله حسبما يقتضي الواقع السياسي. 
- - ربط المقررات الدراسية بالقضايا والمشكلات المجتمعية وتوظيف هذه المقررات في حل

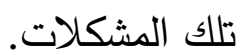

- مراعاة بناء المقررات على أساس من التتكير وليس على أساس من الحفظ أو التلقين. - - ربط مشروعات التخرج بالأنشطة السياسية وجعلها جزءا من المقررات الدراسية.

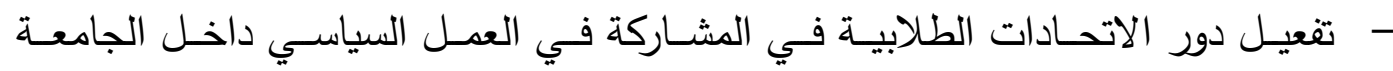
والمجتمع.

- توفير مناخ جامعي داعم لمختلف الأنشطة الجامعية وبخاصة السياسية منها.

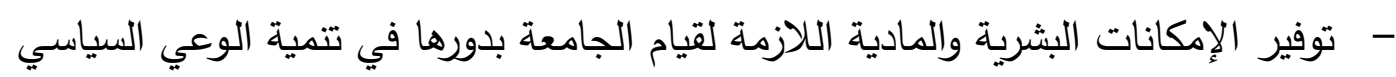
لطلابها. - التواصـل الفعـال بين الجامعـة كمؤسسـة اجتماعيـة تعليميـة وبين الهيئات والمؤسسـات السياسية بالمجتمع.

\section{مراجع باللغة العربية: - ماية}

1- إبراهيم بدران: تطلعات لمصر المستقبل في السياسـة والتنمية البشرية والبحث العلمي، القاهرة، مكتبة نهضة مصر ، 1999.

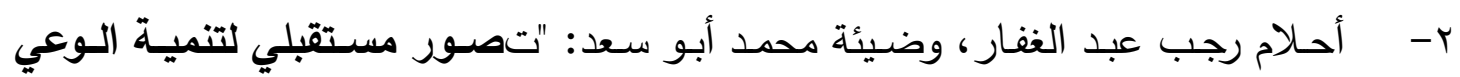

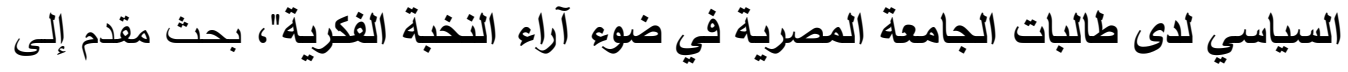

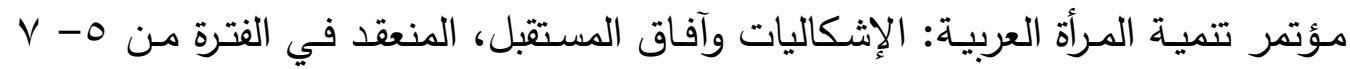

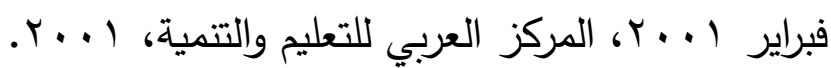




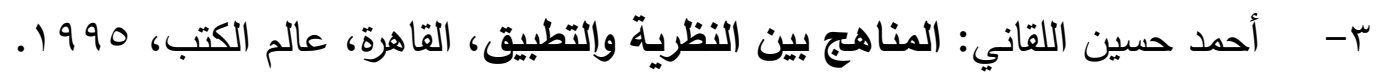

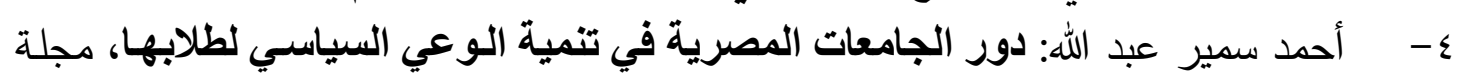

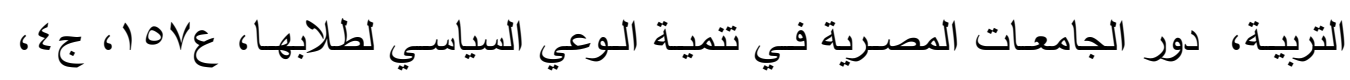

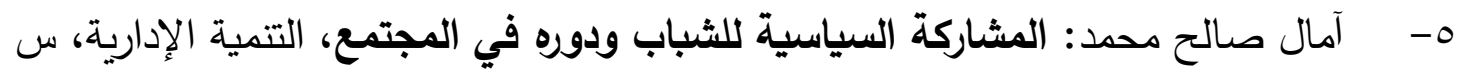

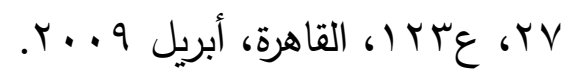
צ- بسام محمد أبو حشيش: دور كليات التربية في تنمية قيم المواطنة لائ الطلبة المعلمين

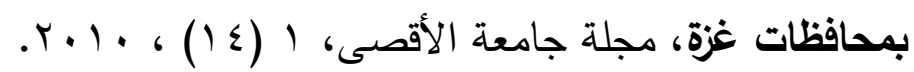

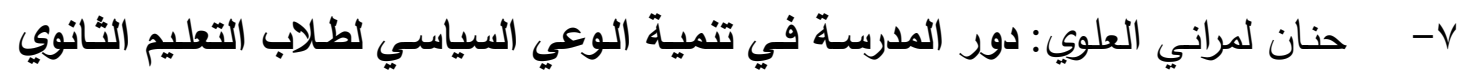

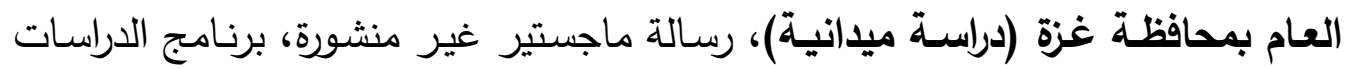

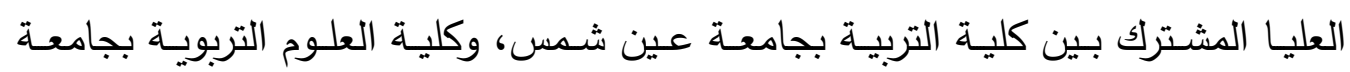
الأقصى، 0. . ب.

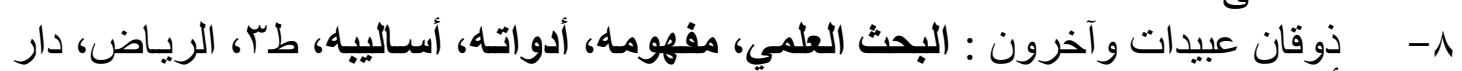

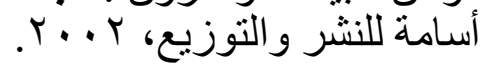
9- ياد محمد الغنيمين: دور إذاعة الجامعة الأردنية في تنمية الوعي السياسي لأى طلبة

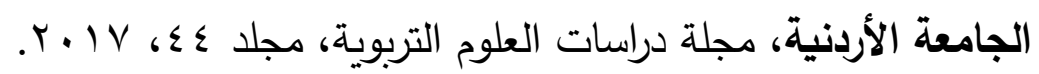

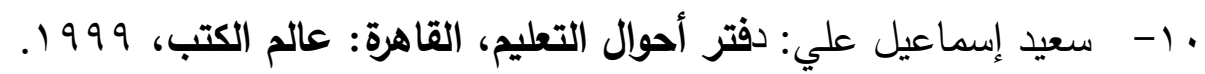

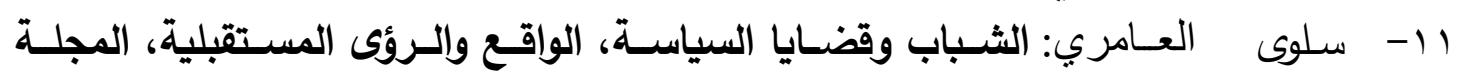

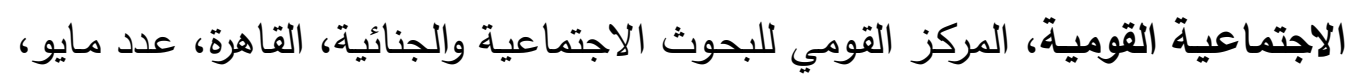
....

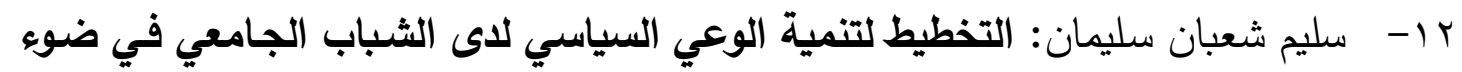

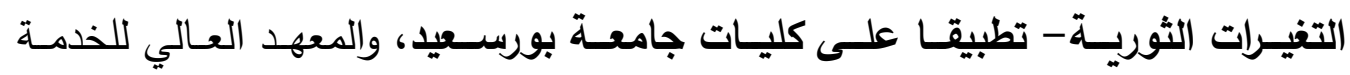

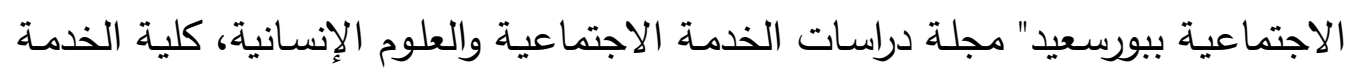

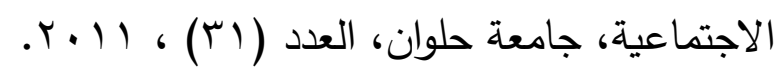

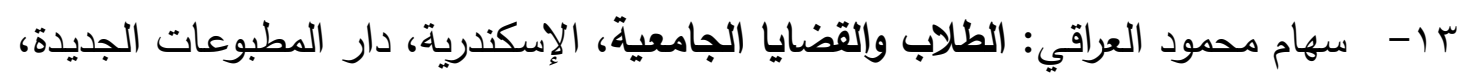
$.199 \varepsilon$

ع ا- السيد سلامة الخميسي: "الطلاب وممارسة العمل السياسي، تحليل ناقد لدورات اتحادات

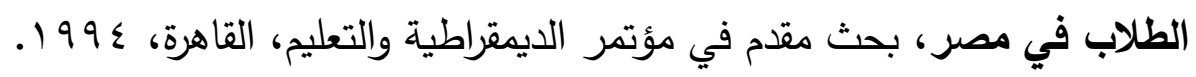

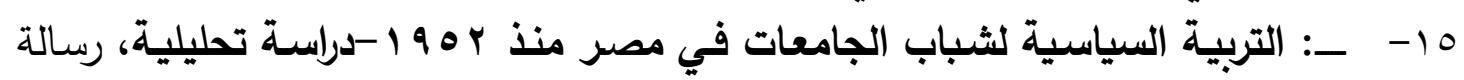

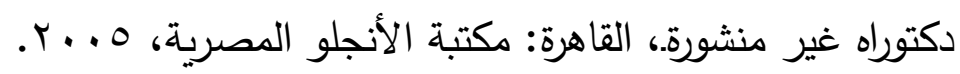
17

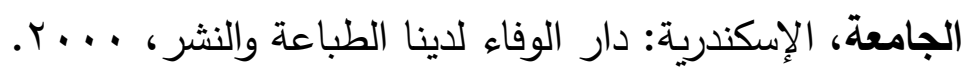




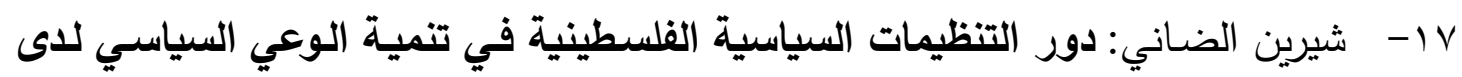

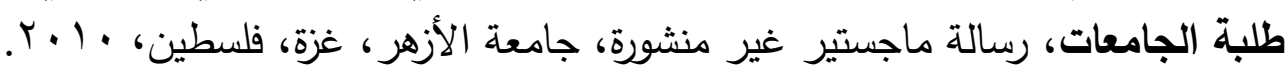

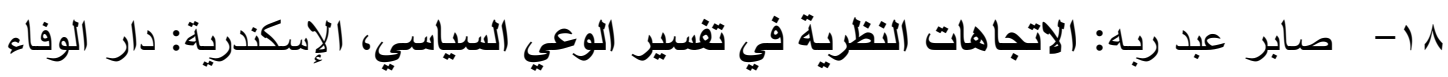
لدنيا الطباعة والنشر، ؟ .. بrم.

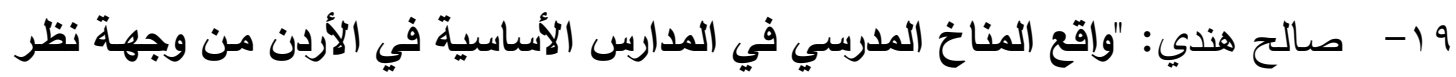

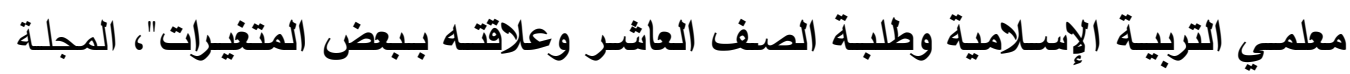

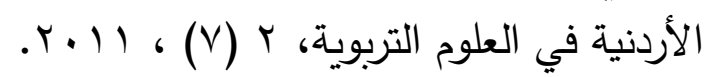

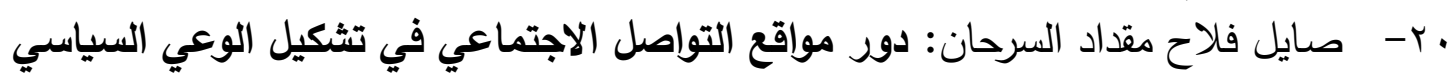

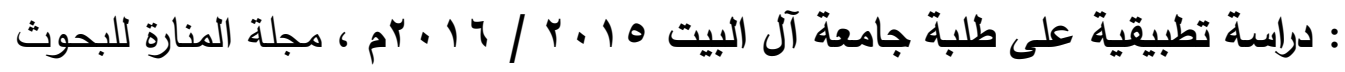

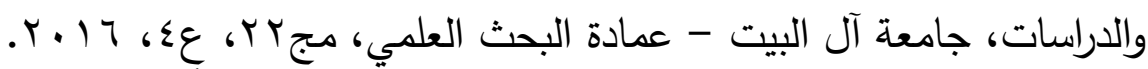

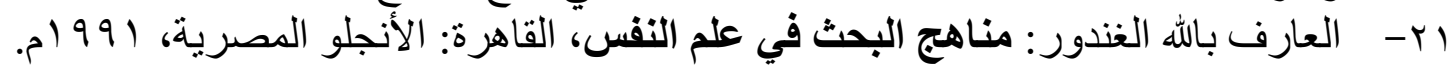

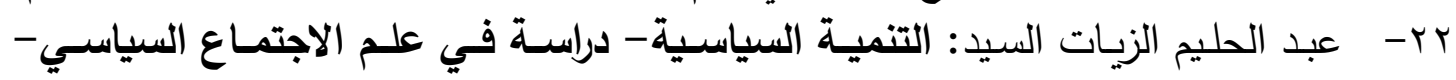

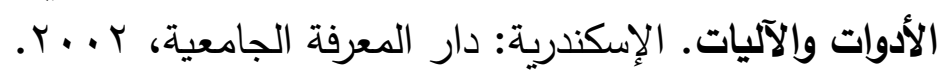

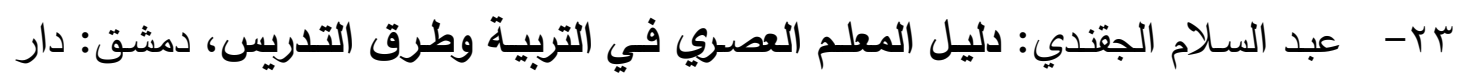

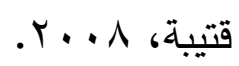

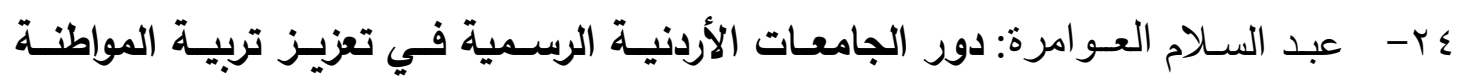

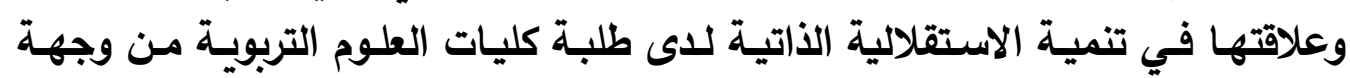

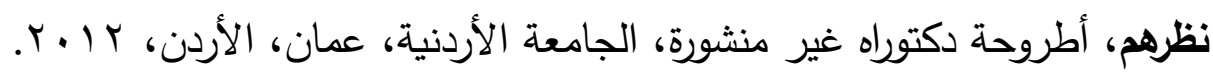

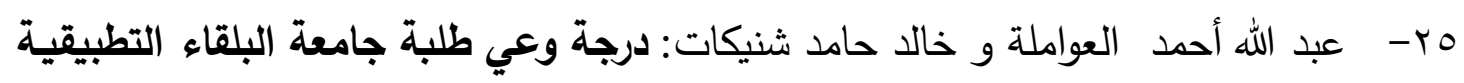

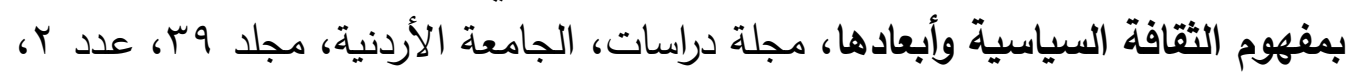
r. T

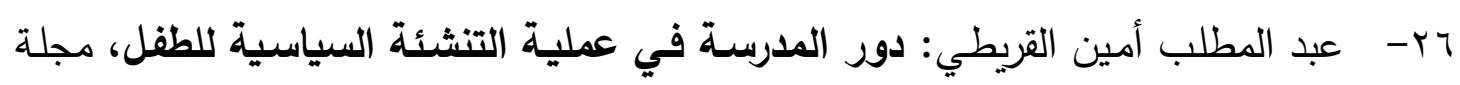

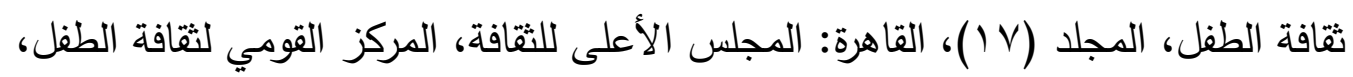
.1997

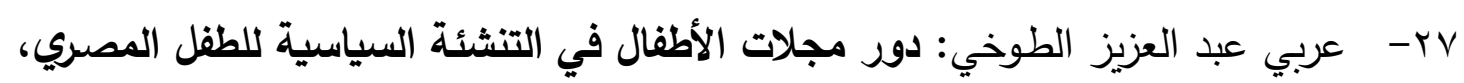

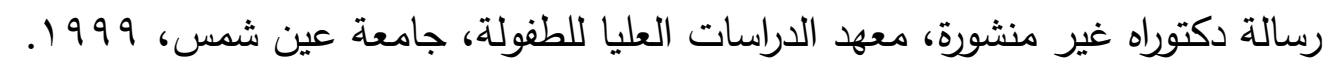

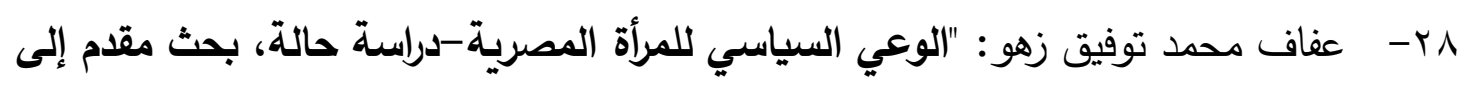

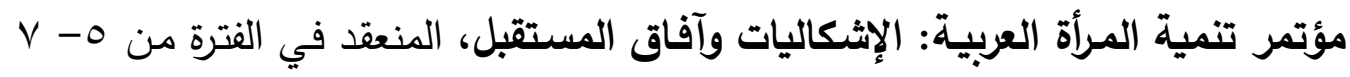

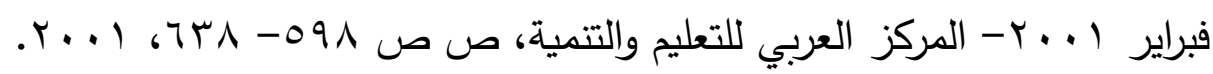

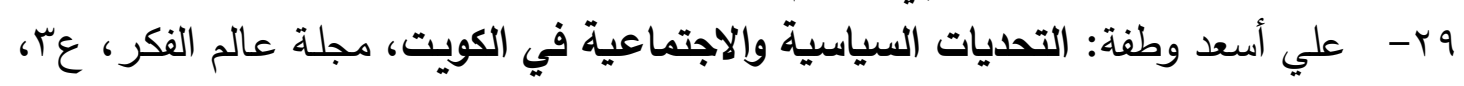

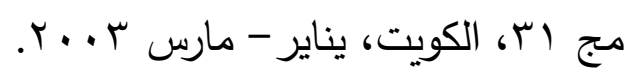

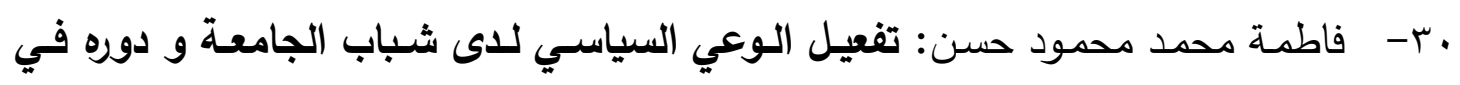

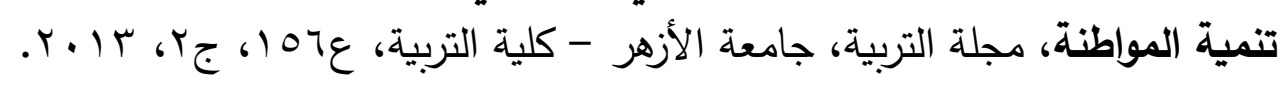


اب- كمال المنوفي، وحسنين توفيق: الثقافة السياسية في مصر بين الاستمرارية والتغيير، القاهرة، مركز البحوث والدراسات السياسية، ؛ 99 1.

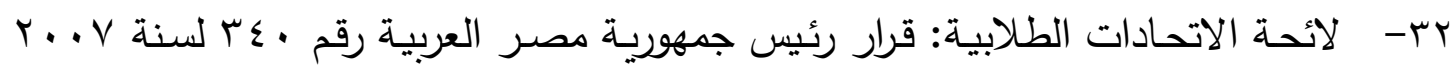

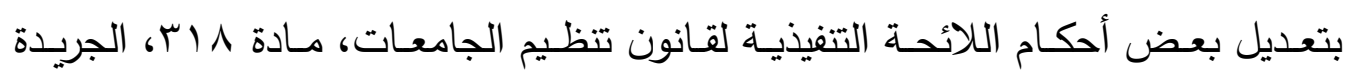

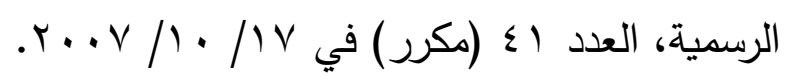

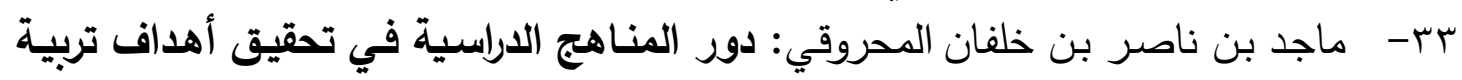

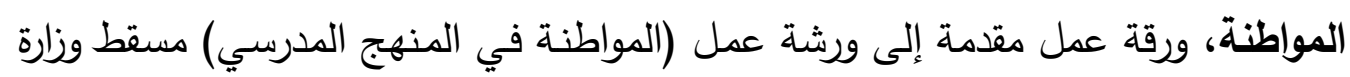

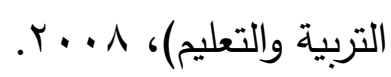

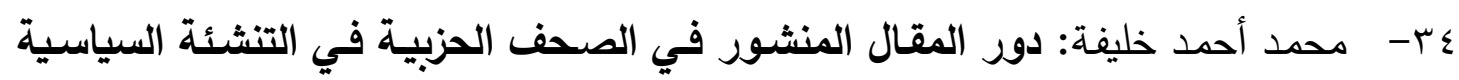

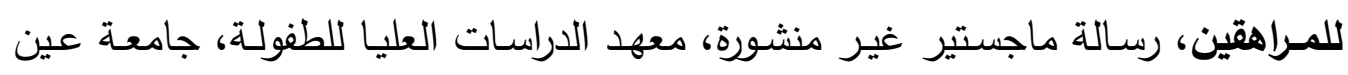

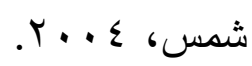
هr- محمد سليم الزبون و رامـا زكي صدقي الحجاوي: دور الجامعسات الأردنيـة في تنميـة الوعي السياسي لاى طلبتها في ظل الربيع العربي وعلاقة ذلك بلك بالإستقلالية الذاتية،

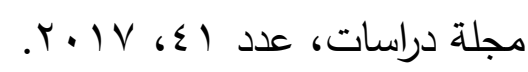
דr- محمود أمين محمد: "الجامعة والمستقبل"، مجلة كلية التربية، جامعة المنيا، العدد الأول، .1991

V r - محمود عساف: الدور التربوي لمجالس طلبة الجامعات الفلسطينية في تثكيل الوعي

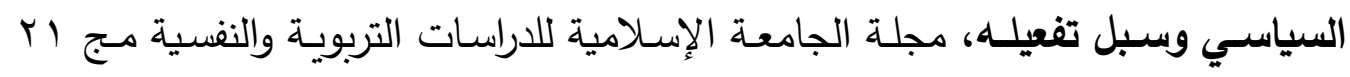

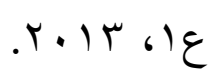

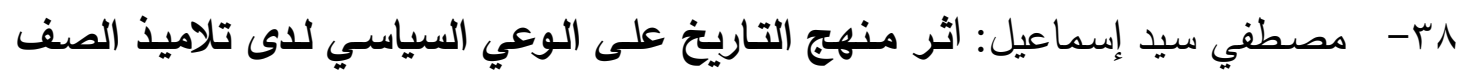

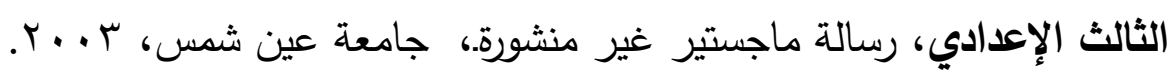

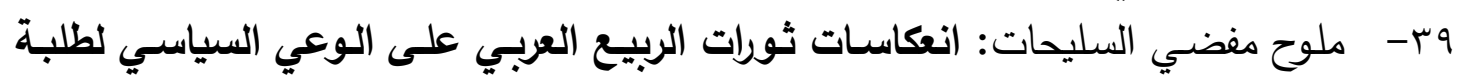

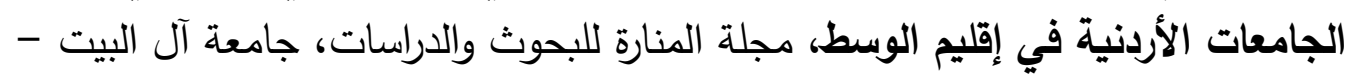

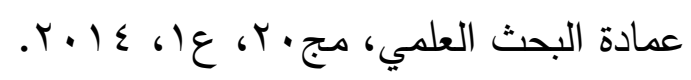

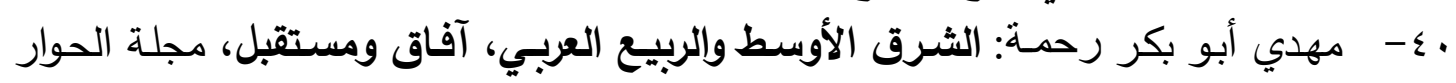

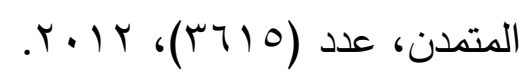

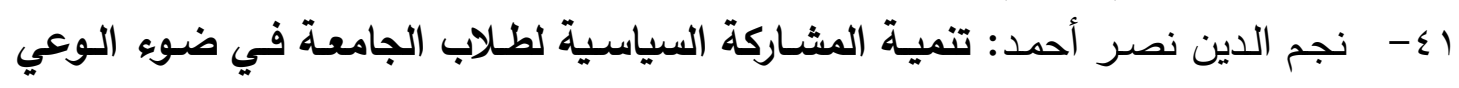

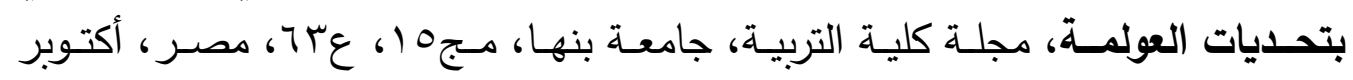
r. . . O

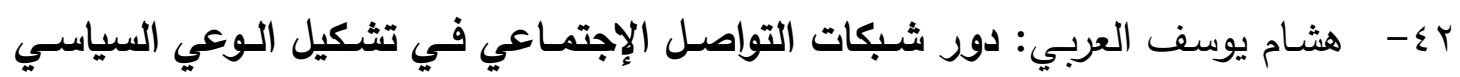

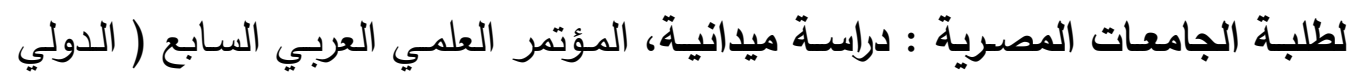

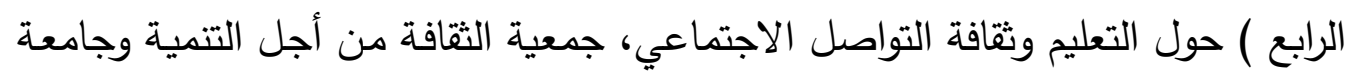


بع - هيام توفيق الربضي: درجـة ممارسـة النشـاطات اللاصفية الموجهة وعلاقتها بتنميـة

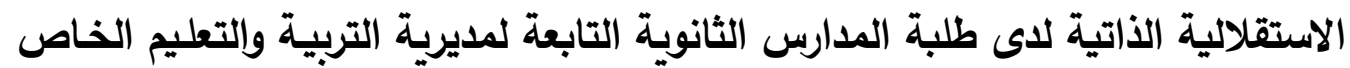

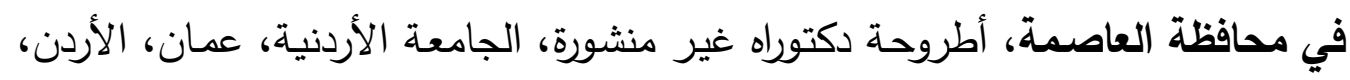

r...

مراجع باللغة الانجليزية:

44- Adelabu, M.A. \&Akinsolu,A.O; "Political education through the university : A survey of Nigerian university students," African Jornal of Political Science and international Relations, 3 (2), 2009, 46-55.

45- Angelique \& Reischl; "Political empowerment evaluations of an intervention with university students," American Journal of Community Psychology, 30(6), 2002, 815-823..

46- Buehler, Susan; "nterpreting political message, political awareness and back ground knowledge among young voters, political science general, Vol 65, 2005.

47- Burno Losito (2003). Civic Education in Italy intended Curriculum and Students' Opportunity to learn, a vailableat: www.sooi.onlineiournal.DE, 2003-21 index .html

48- Hiroshima University bulletin, Collage, 1994-1995, p. vol. 61.Kennesaw State Collage, undergraduate cataloge 1994-1995 Coorgla, 1995- p.p. 1991-1993.

49- Solyom, A; "High school and university student's opinions about politics," Journal of Comparative Research in Anthropology and Sociology, 2(1), 2011,173.

50- University : A survey of Nigerian university students," African Jornal of Political Science and international Relations, 3 (2), 2009, 46-55. 